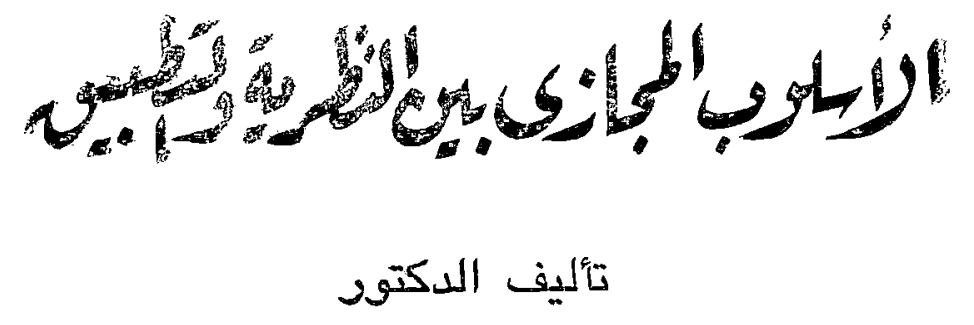

$$
\begin{aligned}
& \text { هلال عطا اله عثمانه }
\end{aligned}
$$

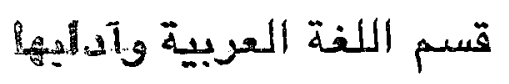

$$
\begin{aligned}
& \text { بلاغة ونقـــد }
\end{aligned}
$$

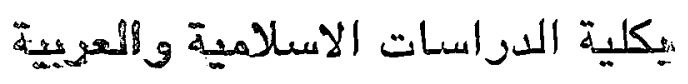

$$
\begin{aligned}
& \text { للبنين بالقاهرة }
\end{aligned}
$$





\section{هقـدهة اليجث}

الهمد الهة رب العالمين ، والصلاة و السلام على المبعوث

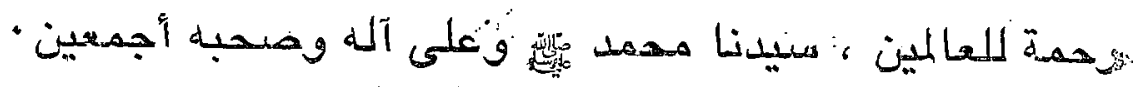

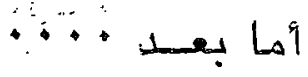

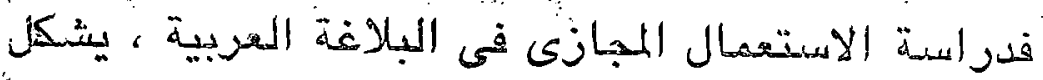

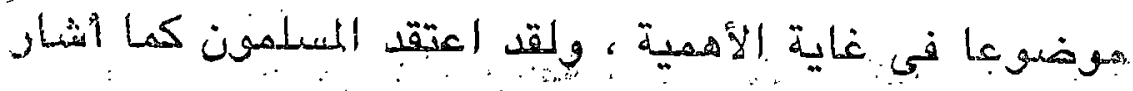

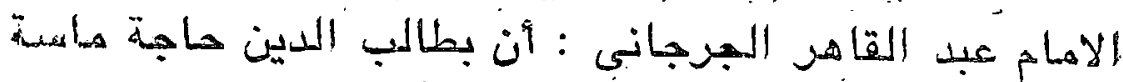

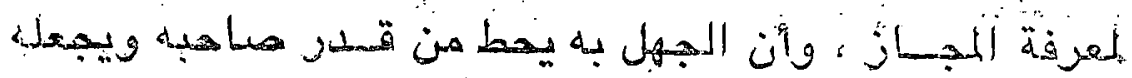

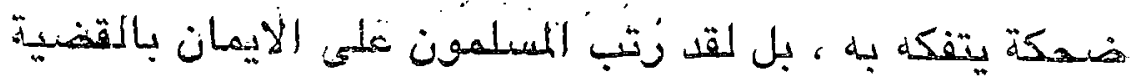

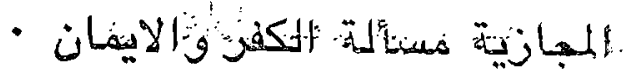

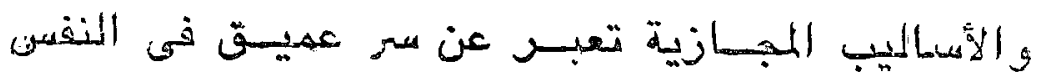

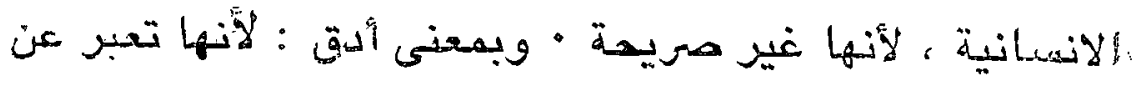

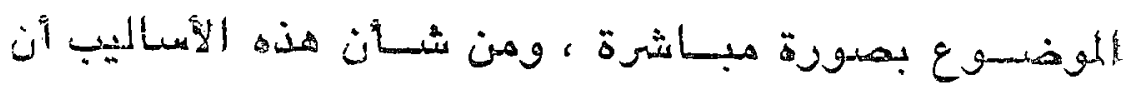

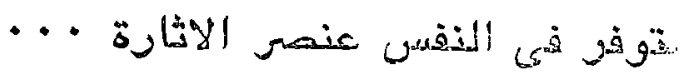

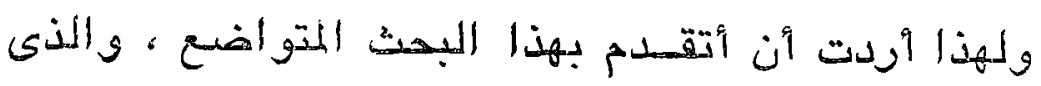

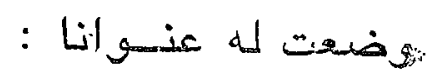

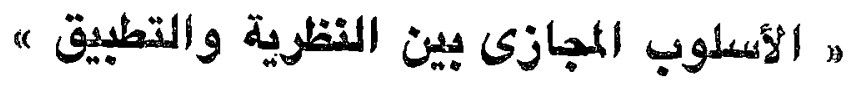

$$
\text { وقسمته أريجة مباهث : }
$$

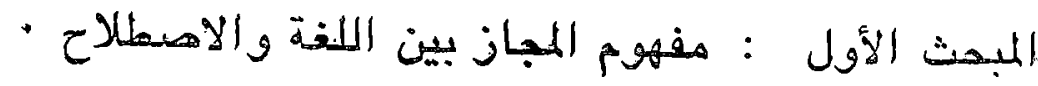

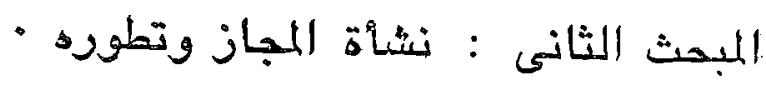

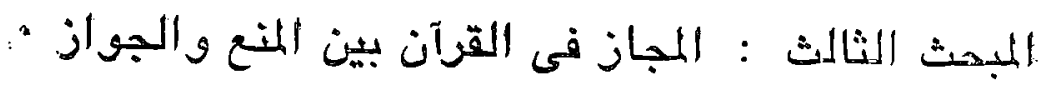

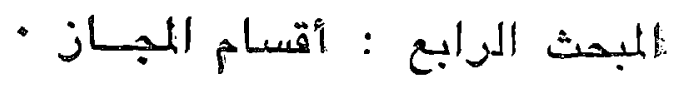




$$
\begin{aligned}
& \text { - rro }
\end{aligned}
$$

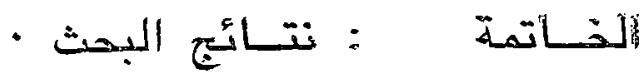

$$
\begin{aligned}
& \text { : هراجيح البهم: }
\end{aligned}
$$

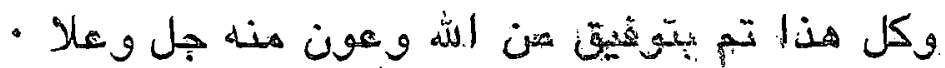

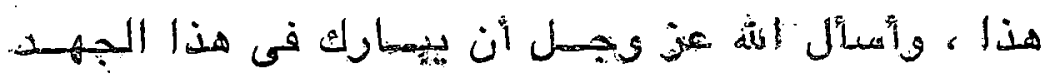

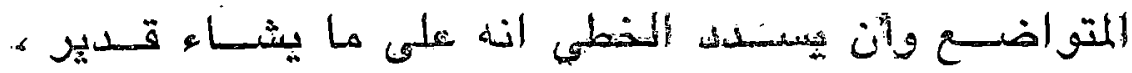

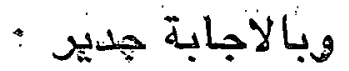

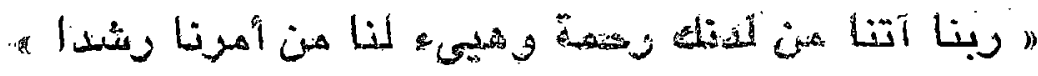

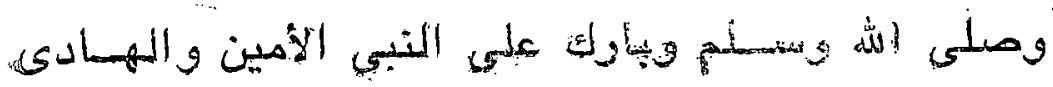

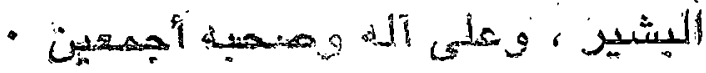

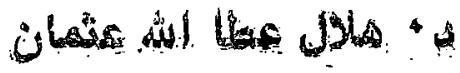




\section{المينثة الأول}

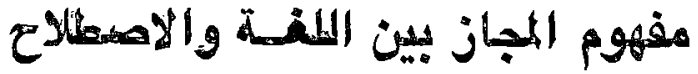

فى اللفة : جاز الموضسع جوازا وجمازا ومجمازا : سيار

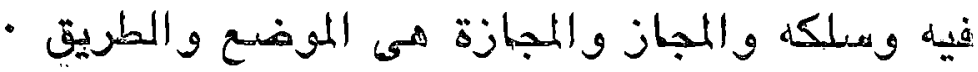

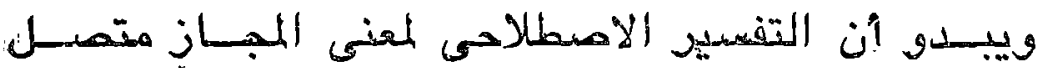

بالمعنى اللذوى ، فقد أكد عبد القاهر الجرجانى العلاتقة بين

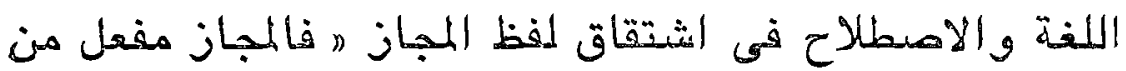
جاز الثيهء يجوزه اذا تعداه ، اذ عدل باللفظ عما يوجيبه

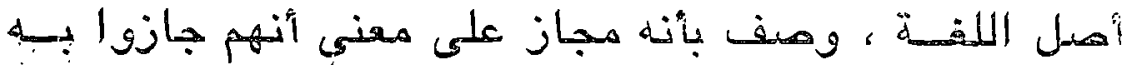

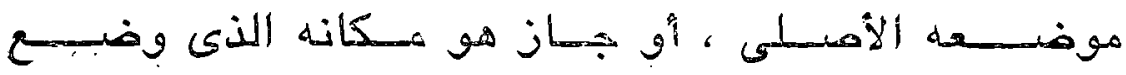

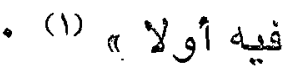

والامام عبد القاهر لا يكتفى، بذلك هتى يحدب العببلاقة

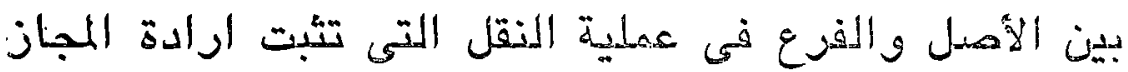

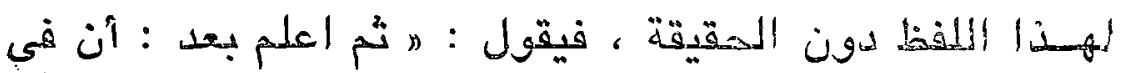

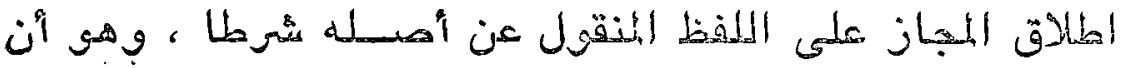

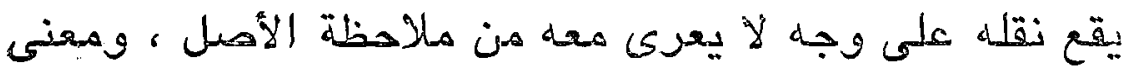

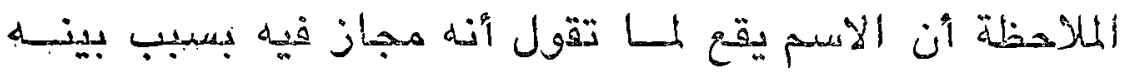

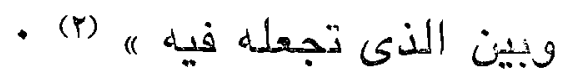

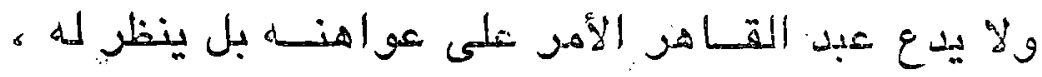

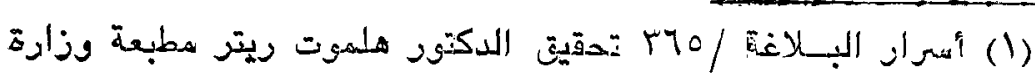

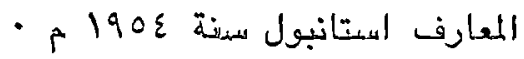

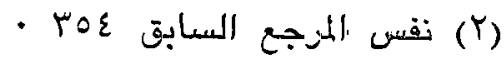


ويطبق على نموذجه ، ويحلل المناسـبة القائمة بين الأصدل

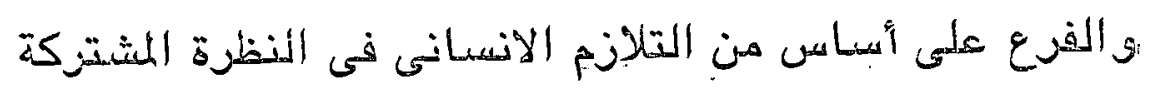

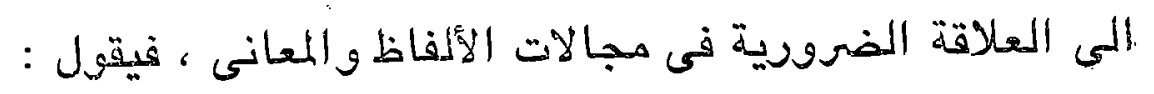

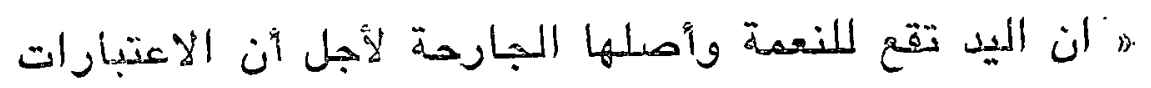

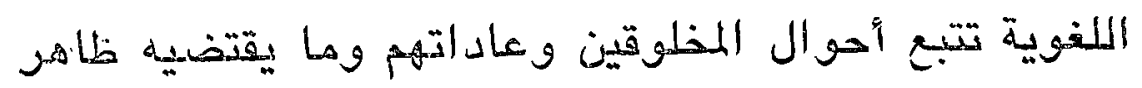

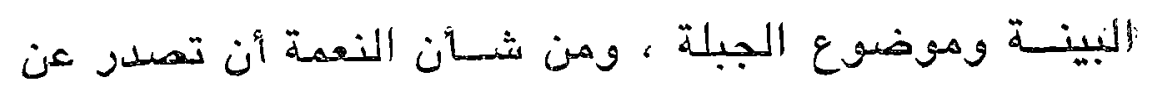

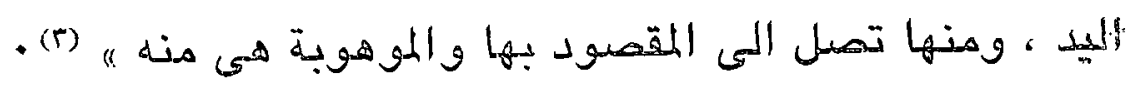

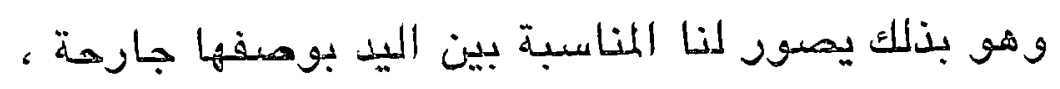

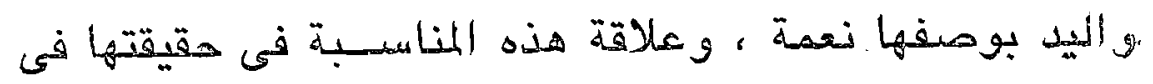

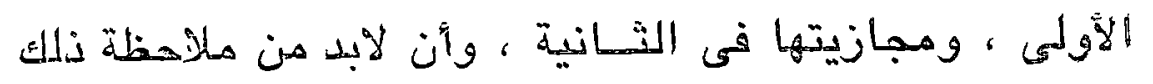

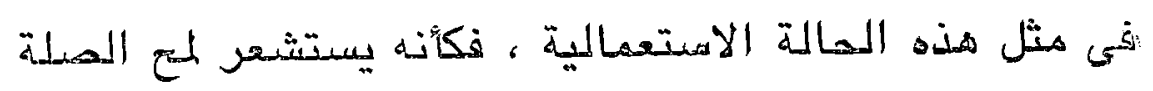

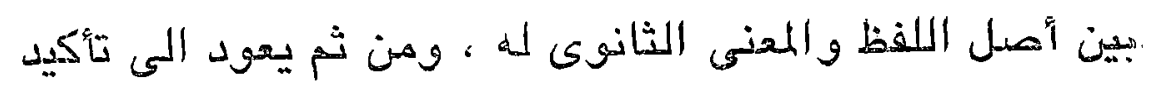

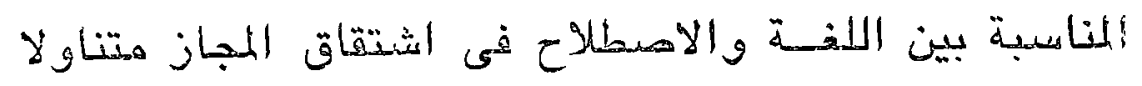

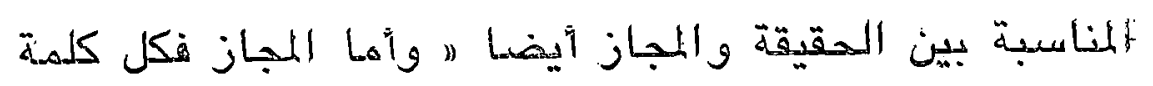

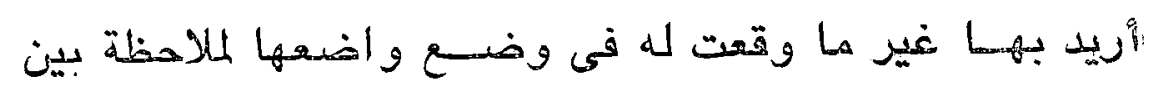

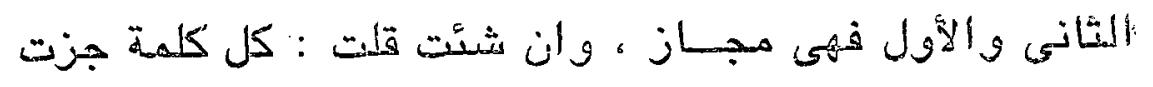

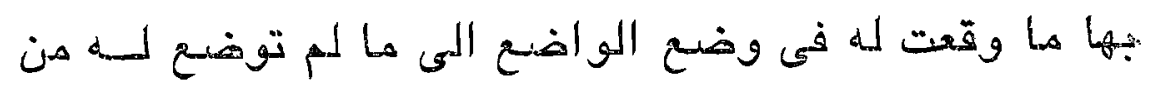

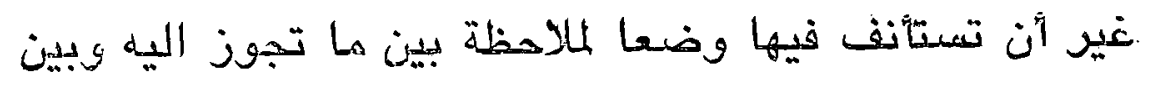

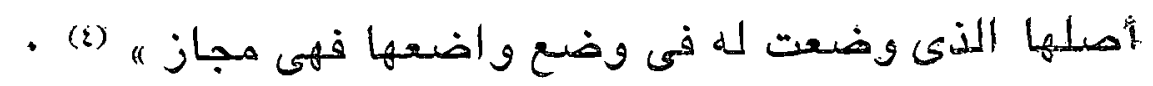

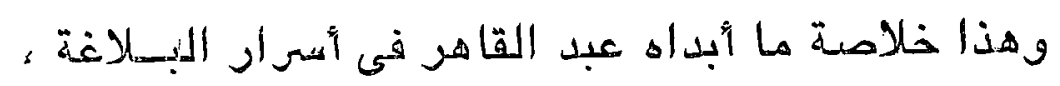




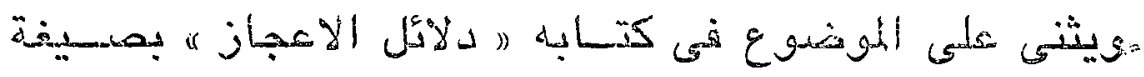

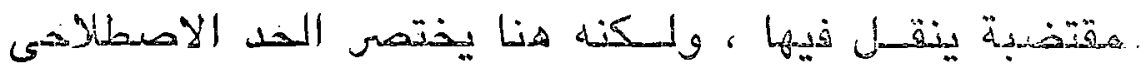

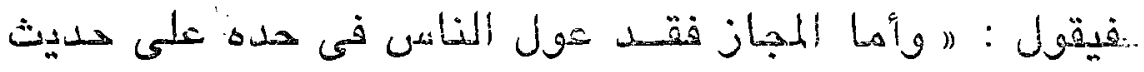

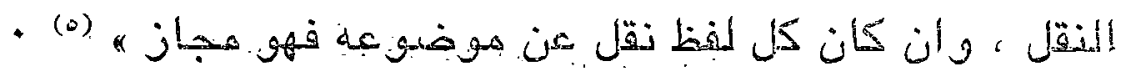

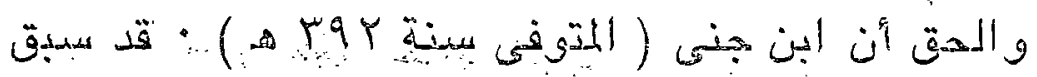

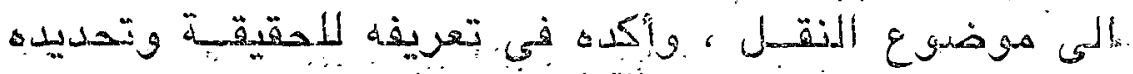

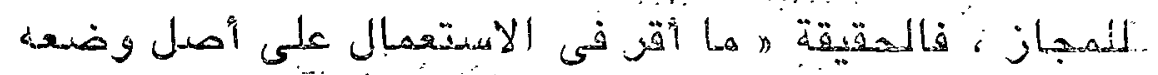

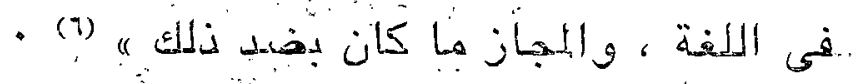

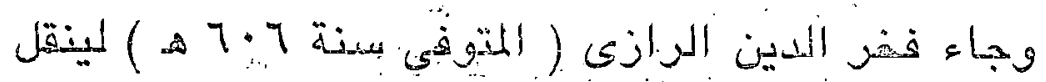

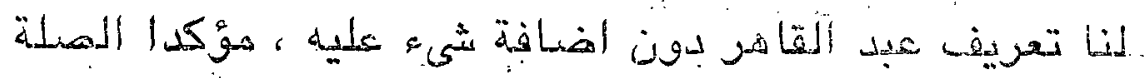

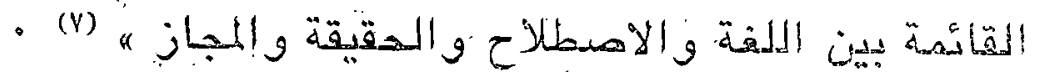

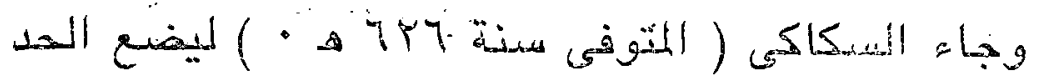

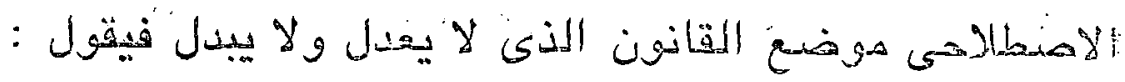

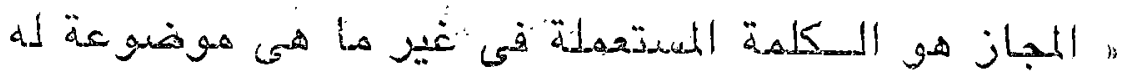

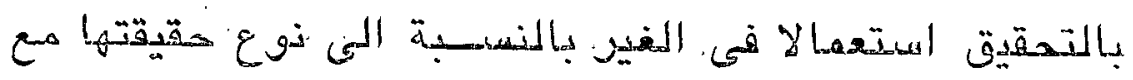

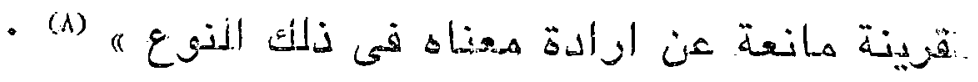

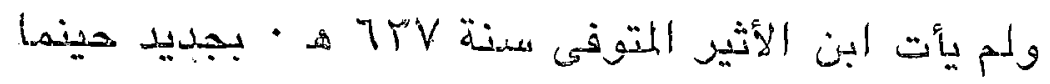

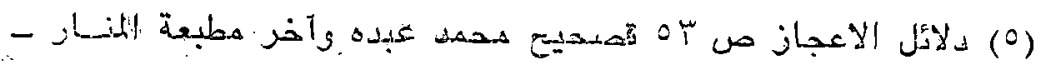
- ها

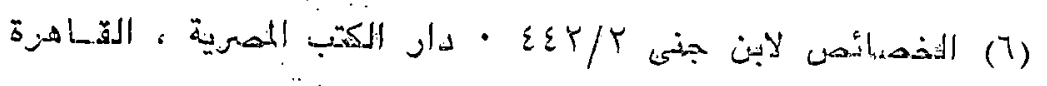

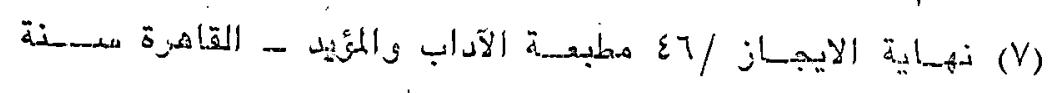

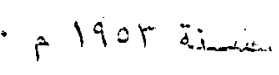
A $14 y^{\circ}$

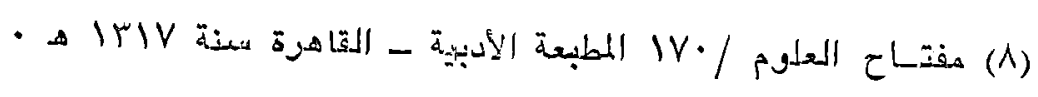




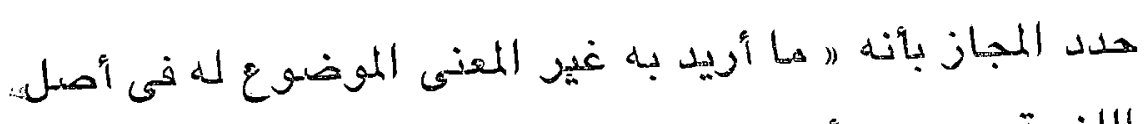

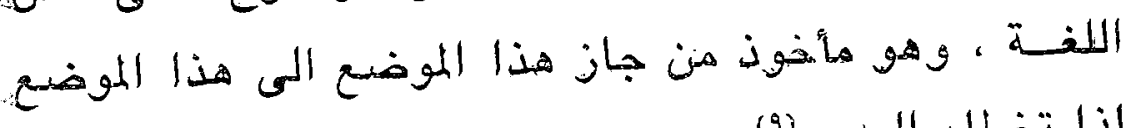

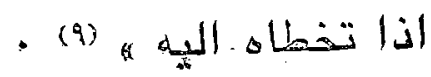

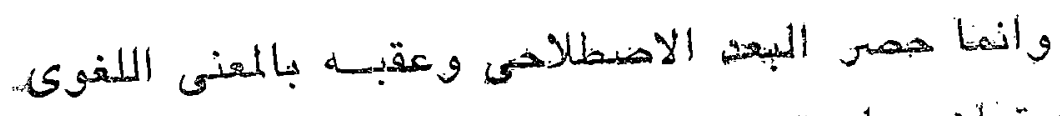

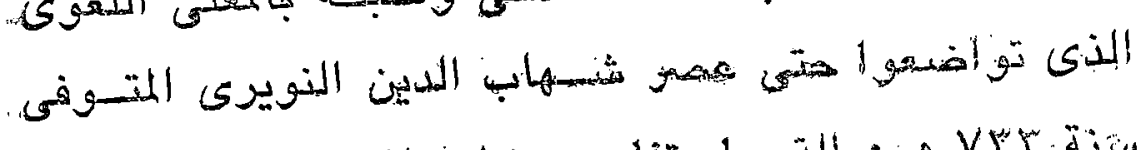

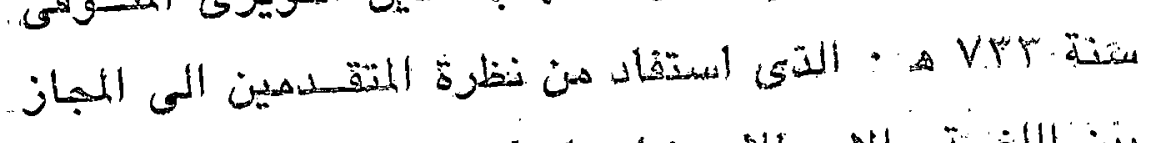

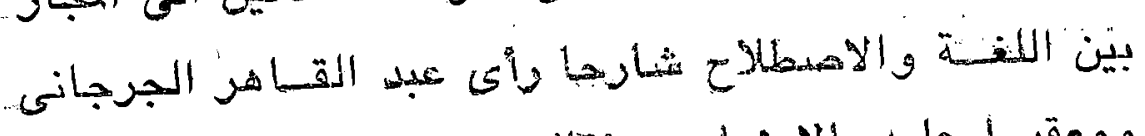

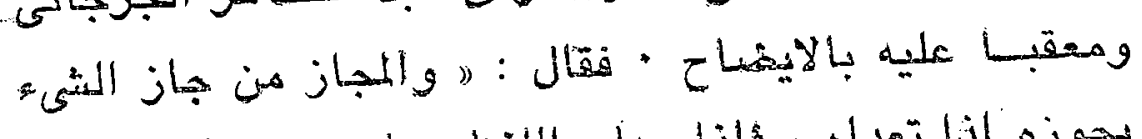

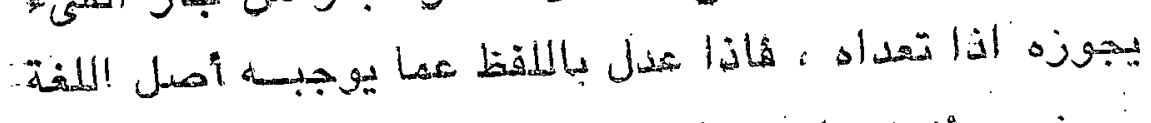

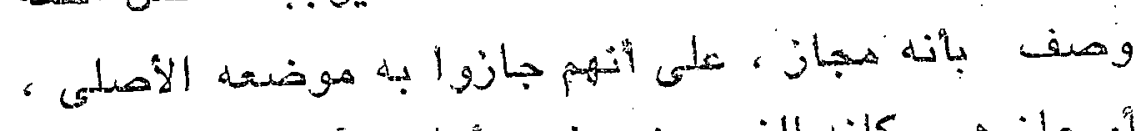

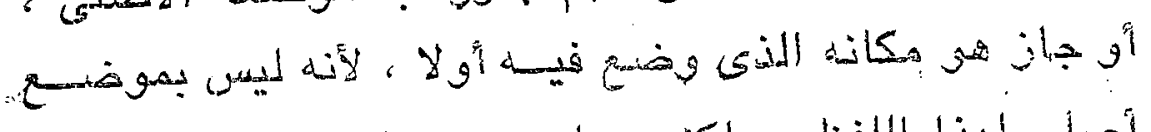

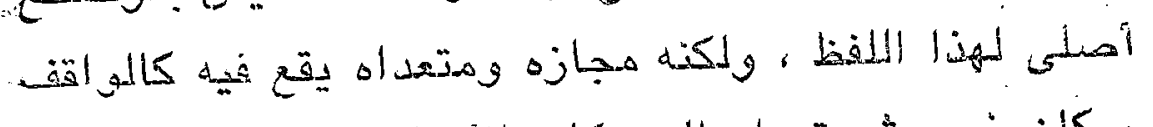

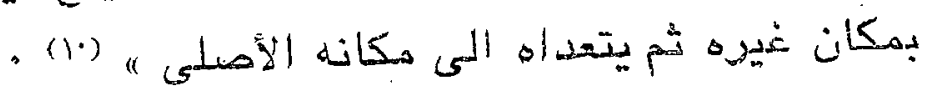

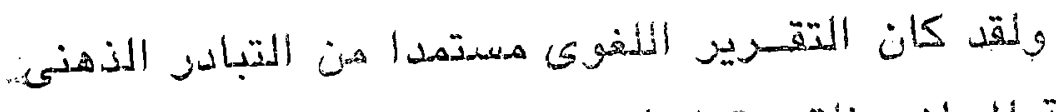

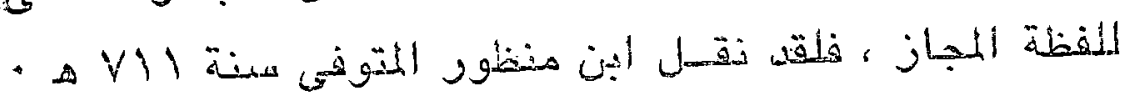

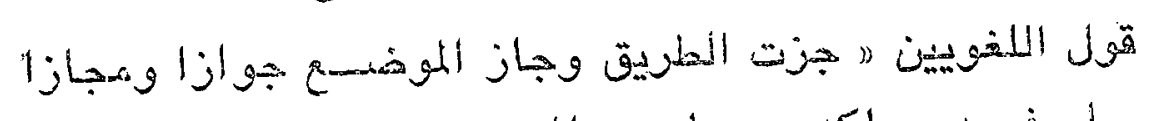

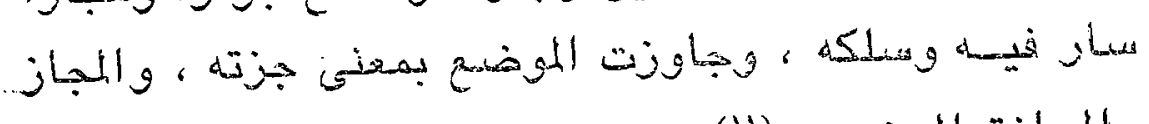

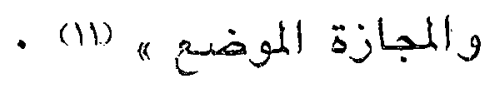

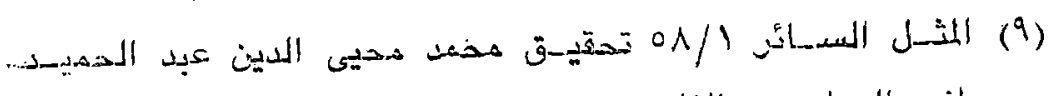

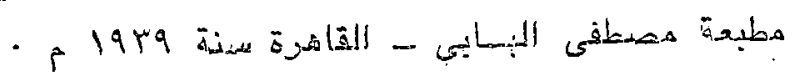

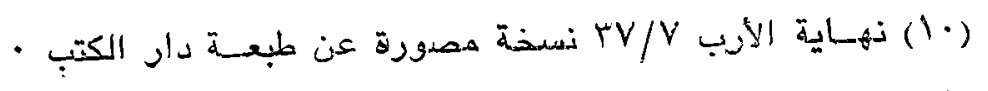

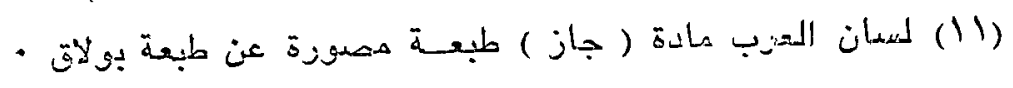




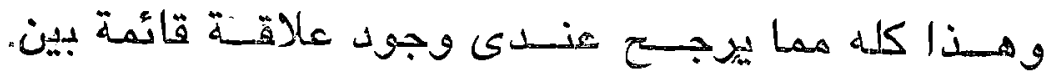

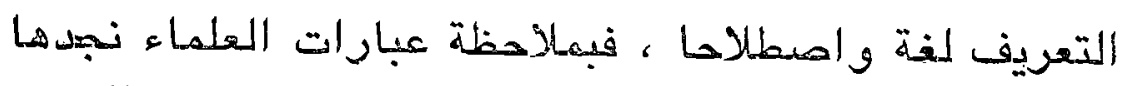

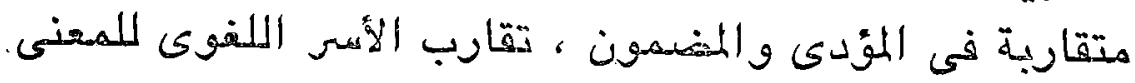

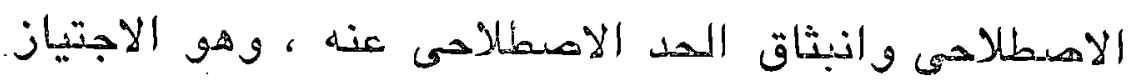

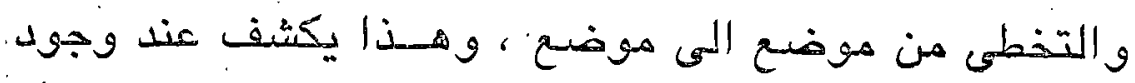

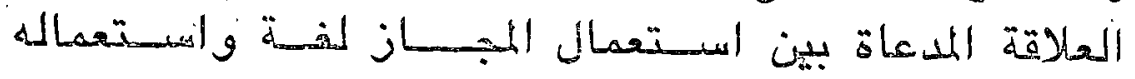

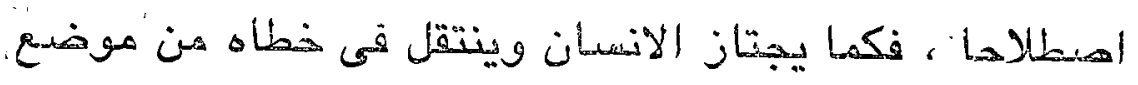

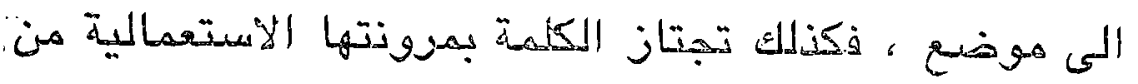

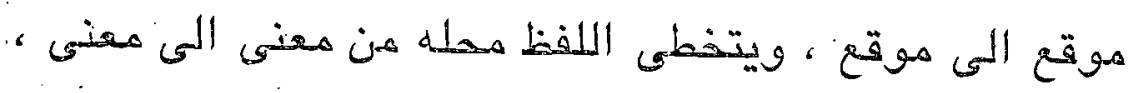

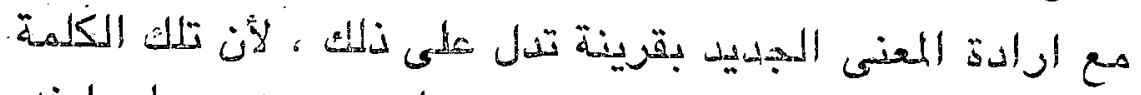

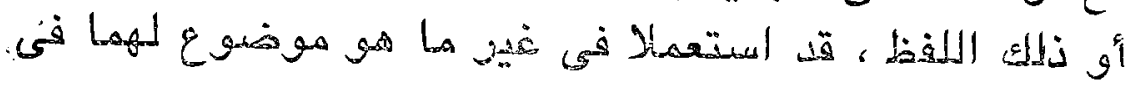

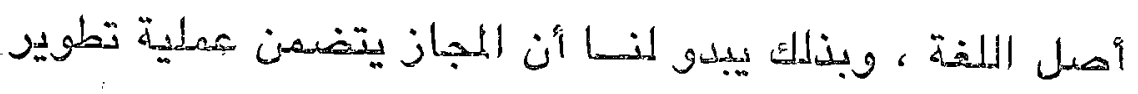

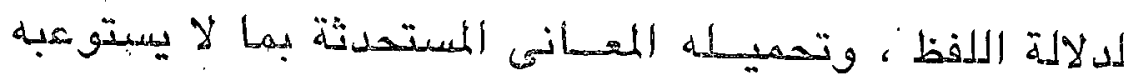

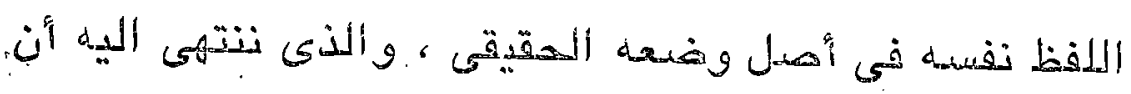

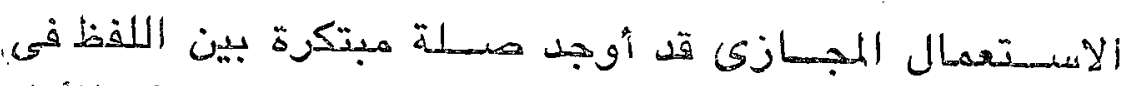

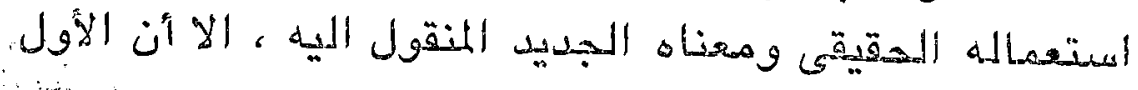

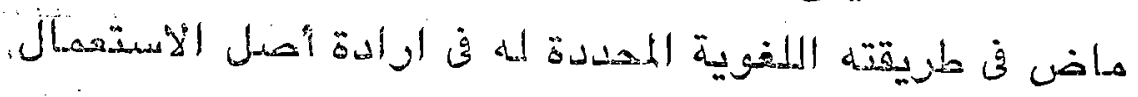

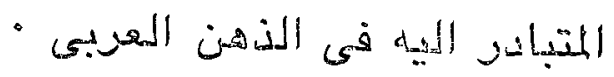

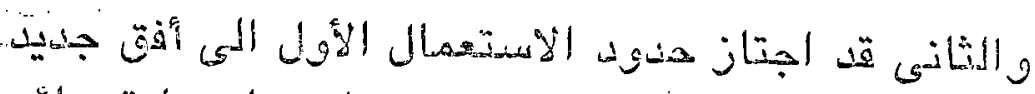

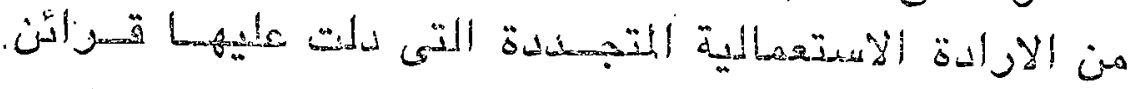

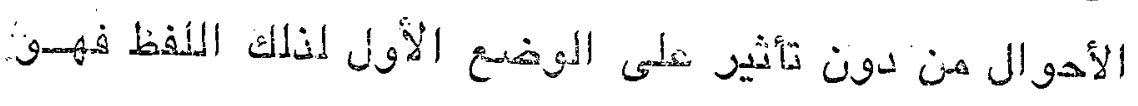

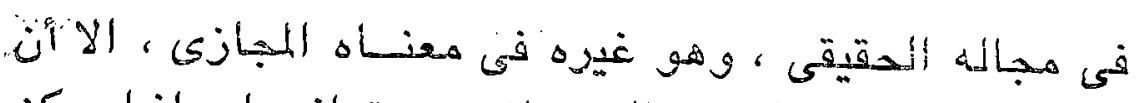

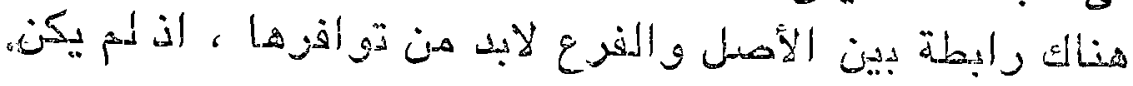

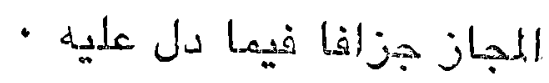


(5)

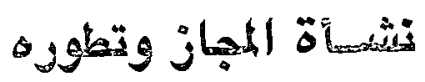

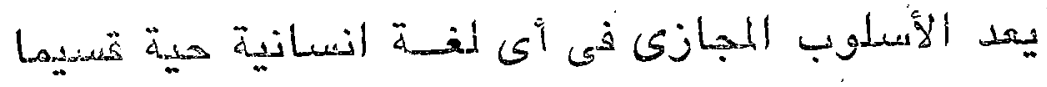

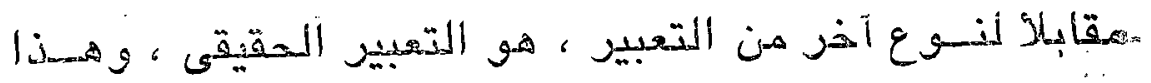

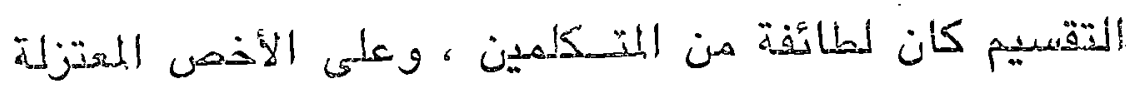

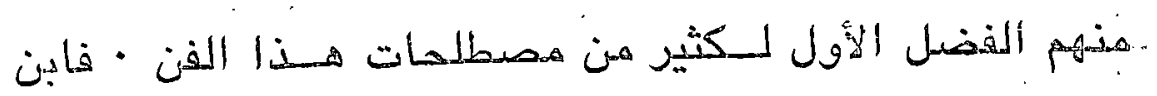

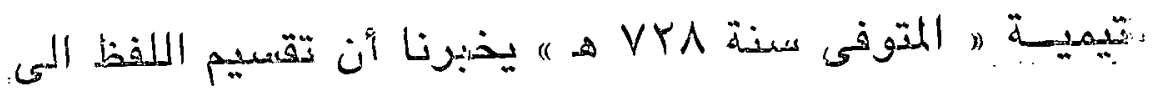

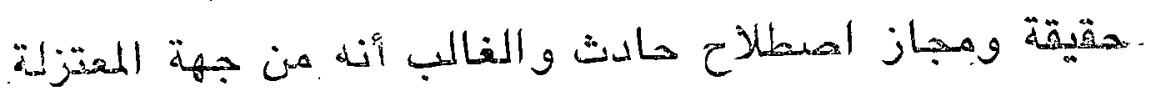

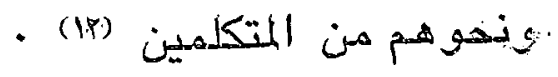

ولم يكن الققل بالمجاز فى اللفة الميربية موضيح اتفـاق

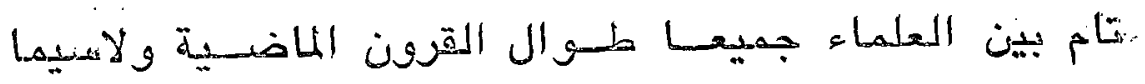

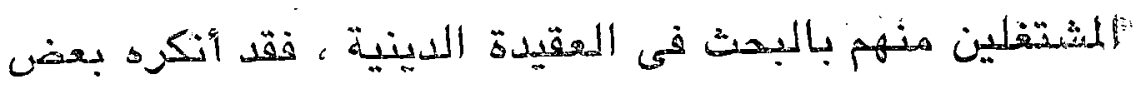

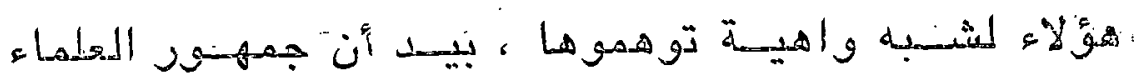

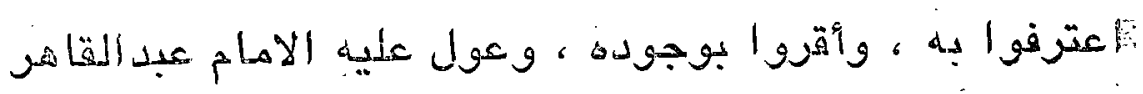

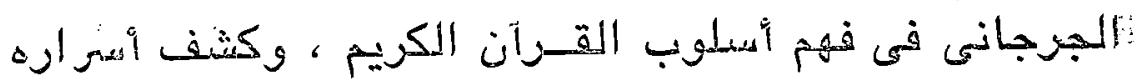

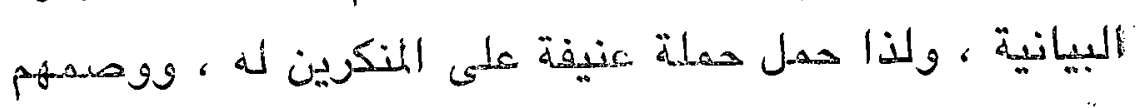

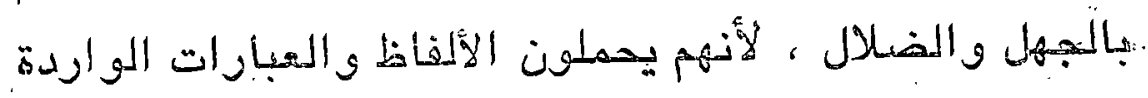

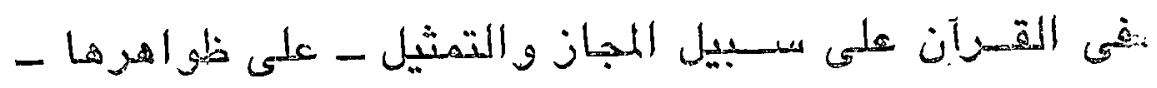

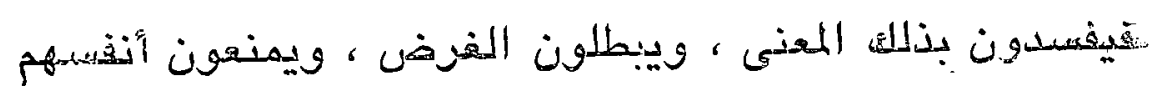




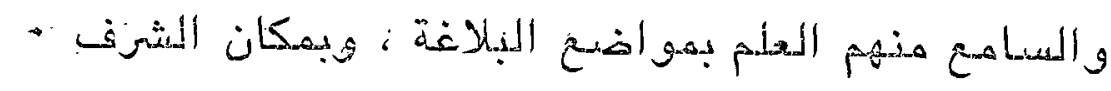

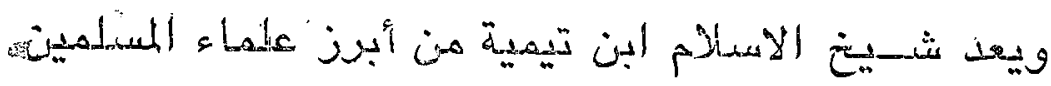

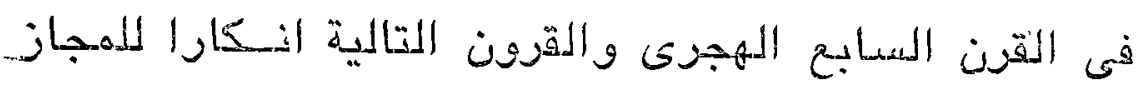

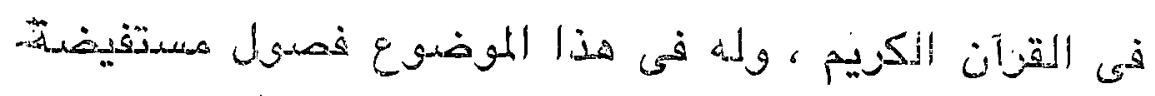

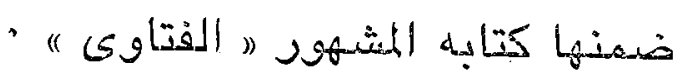

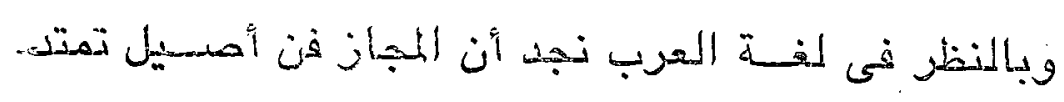

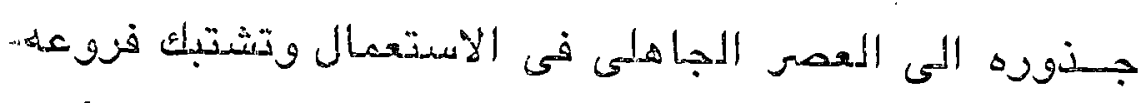

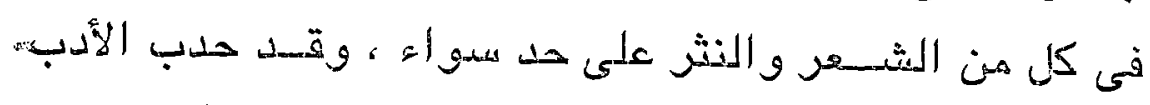

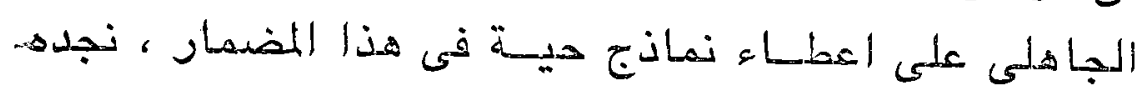

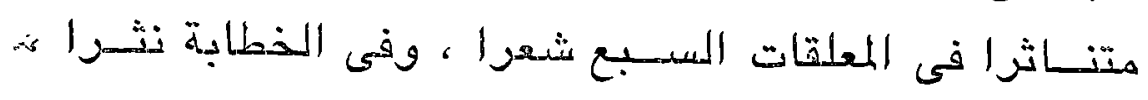

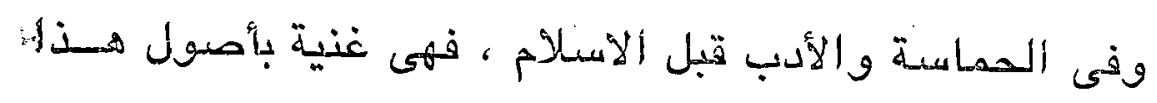

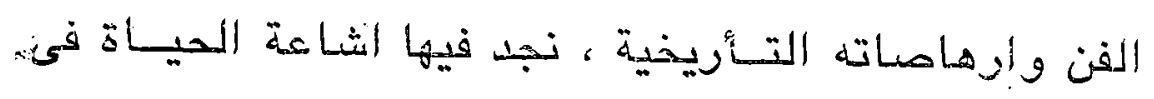

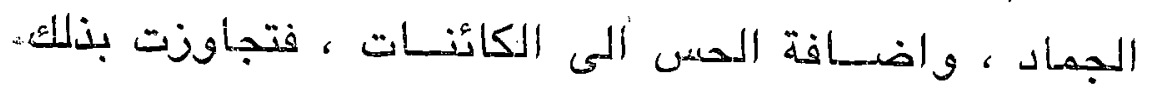

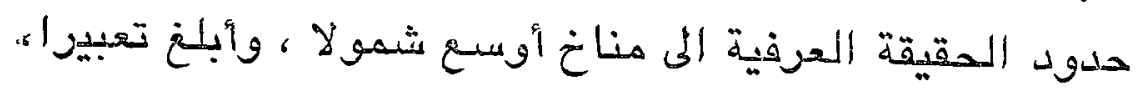

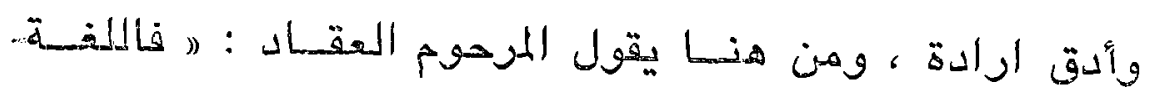

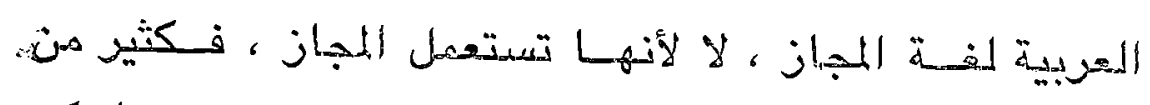

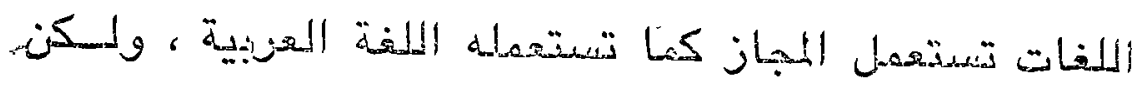

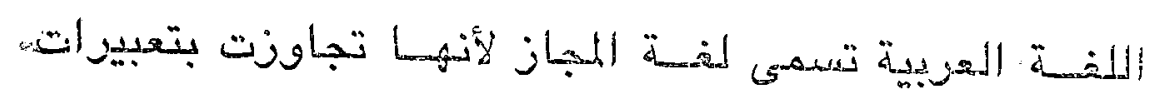

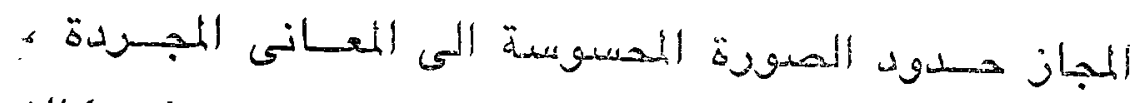

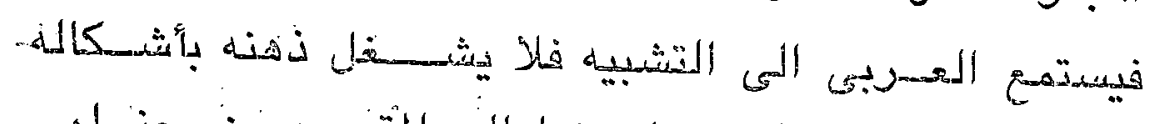

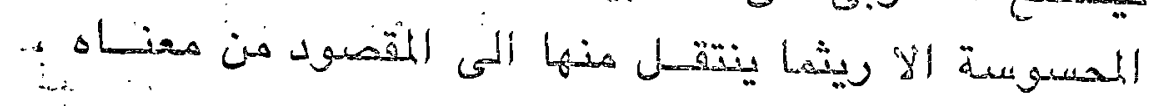

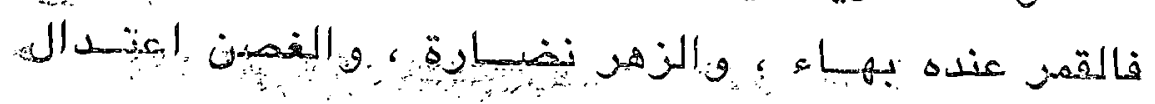


: ورشاقة ، و الطود وقار وسكينة " (Ir) :

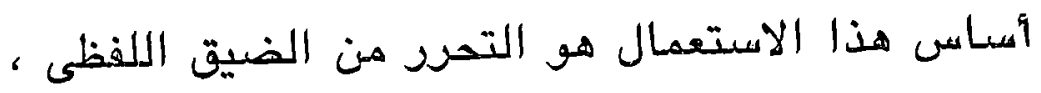

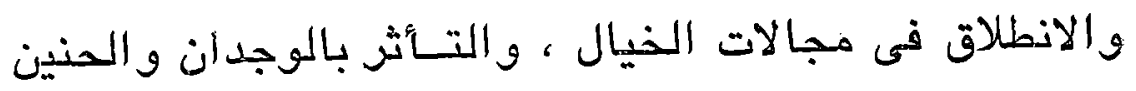

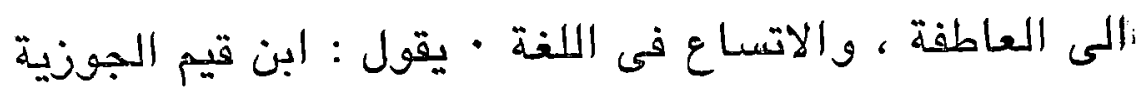

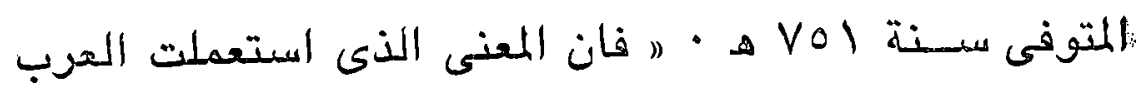

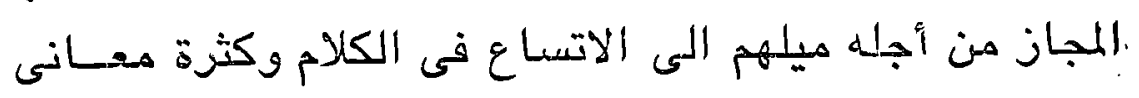

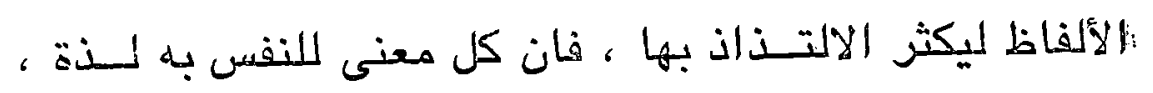
ولبها الى فهمه ارتياح وصبوة ، وكلما دق المعنى رق منثروبيه

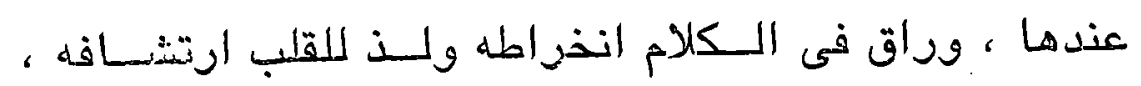

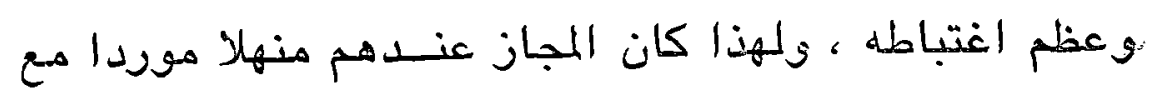

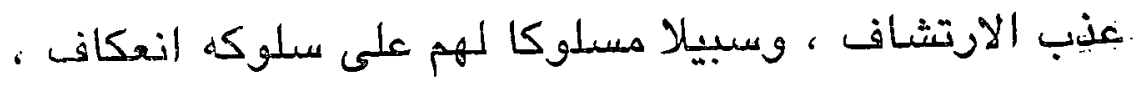

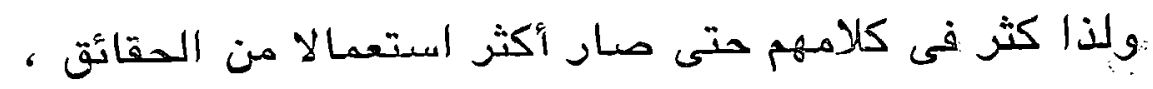

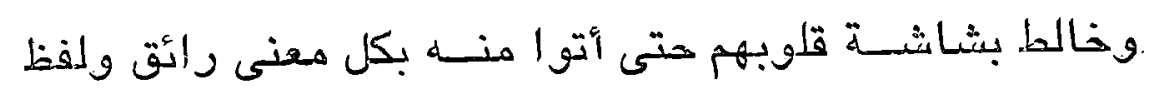

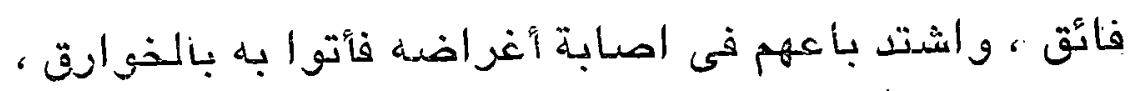

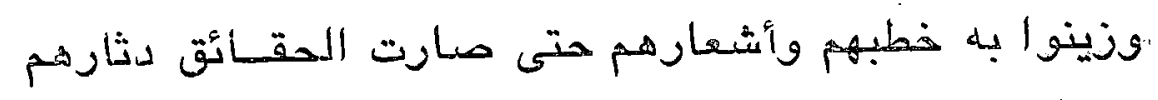

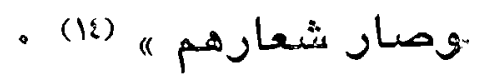

ولذا يدى بعه البهاغيين أن المجاز هو ملم البيـان

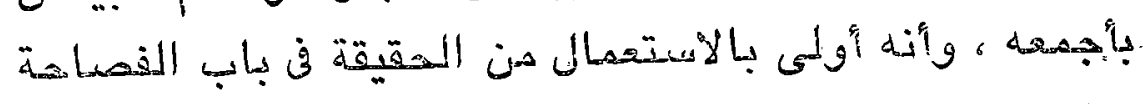

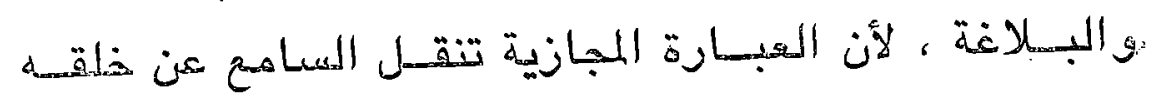

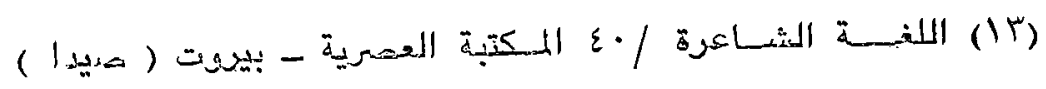
- dit

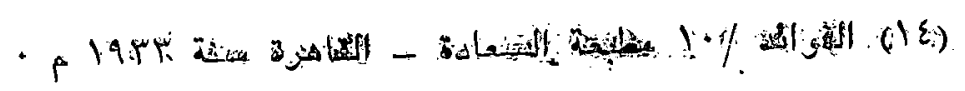




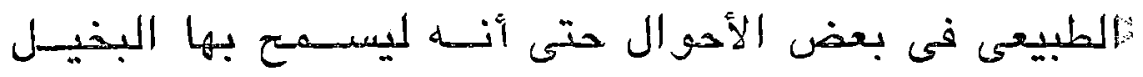

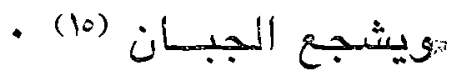

ونزل القــرآن الكريم بجزيرة العرب ، فـكان المعج-زة

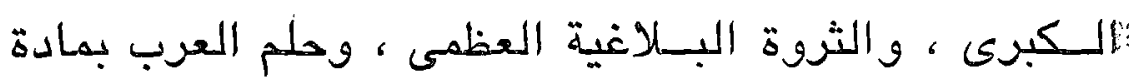

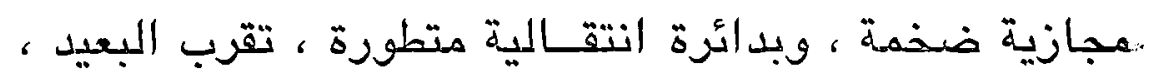

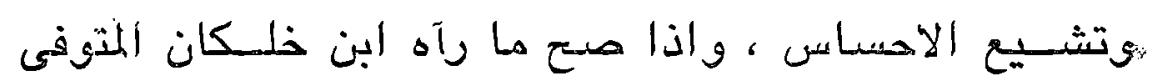

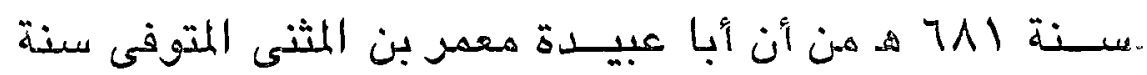

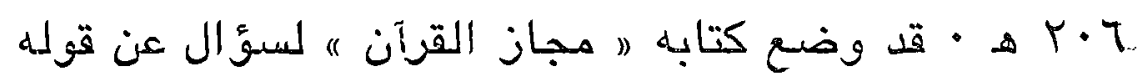

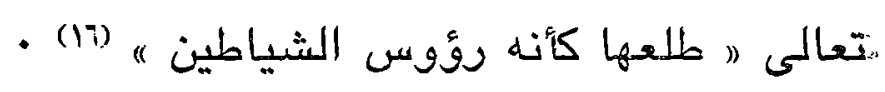

كيف يكون الوعـد والايعــــاد بما لم يعـرف ؟ قــال : أبو عبيدة :

" فقلت انما كلم الله العرب على قدر كلامهم أما سمعت : لمرت

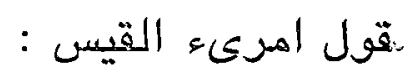

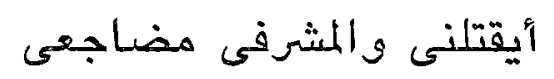
ومسنونة زرق كأنياب أغقوال

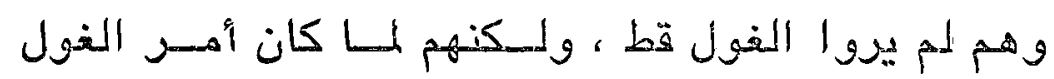

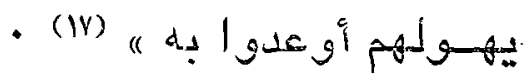

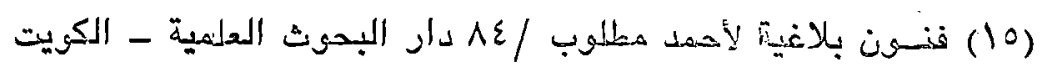
- 19Vo - 70 آية (17)

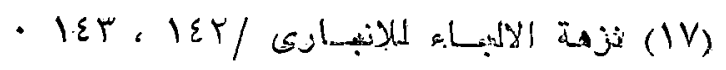


وقد عزم أبو عبيدة عيلى تأليف كتابه ( هجاز القـــآن )؛

اثز هذه الحادثة .

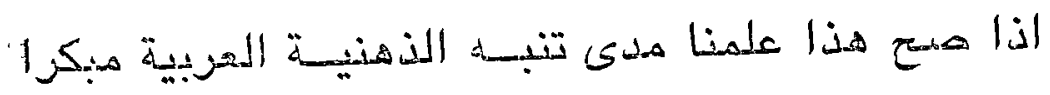

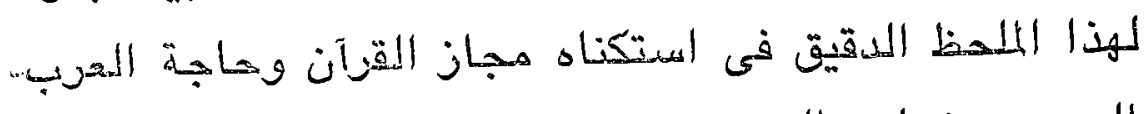

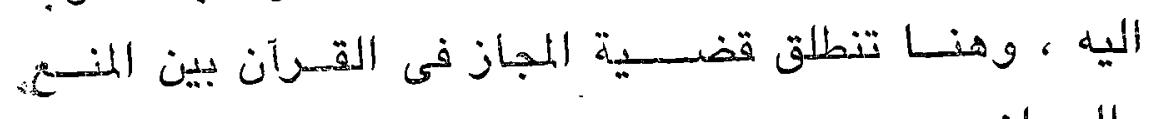

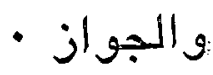




\section{المبداث الثباث}

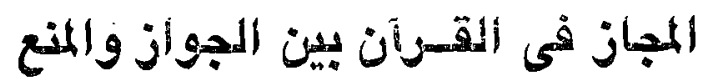

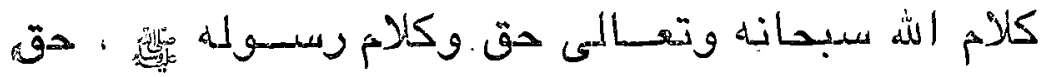

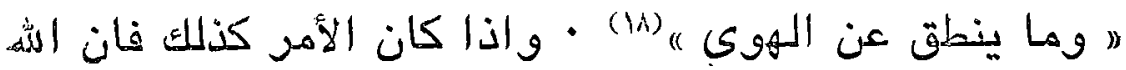

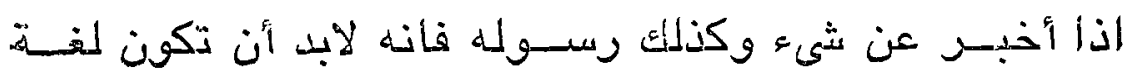

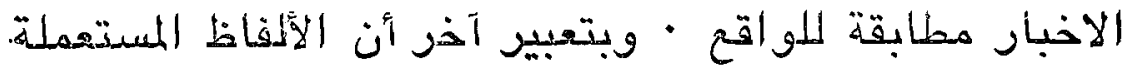
في القــرآن الكريم والحديث النبوى الثئيف يجب أن تكوني قد وضعت لتفيد المعانى المتبالدرة الى الذهن و المرتبطة إبتد أه بتلك الألفـاظ ، ذلك لكى تكون لغة الاخبـار صادقة ، اذ آن

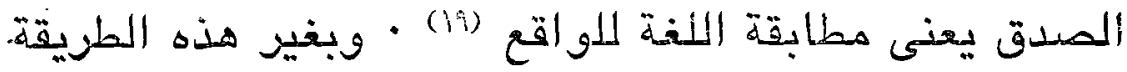
تكون لغة الاخبار كانبة • وهذا أهدر فطير انقسم إلمسلمون.

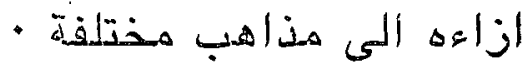

1

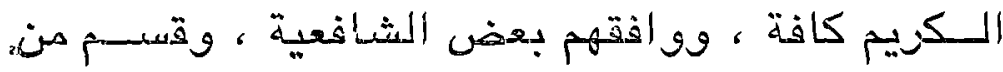

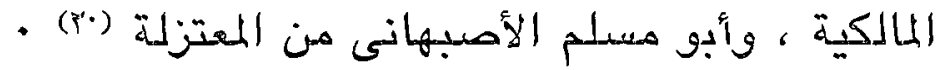

وقد جاء هذا الرغض بحجهـة أن المجبـاز أخو الـكنب ه.

والقرآن الكريم منزه عنه ، ذان المتـكلم لا يعدل اليه الا اذهابه

$$
\text { • ب الآية (1/) }
$$

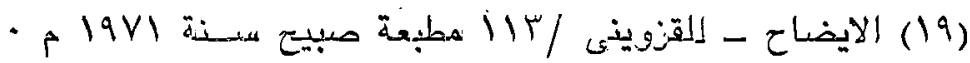

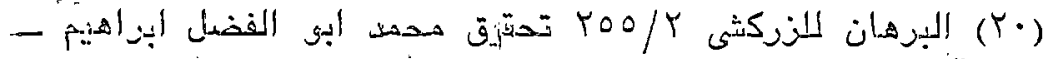

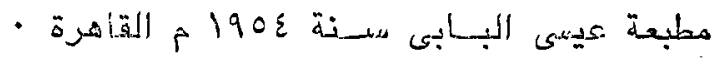

( ) 


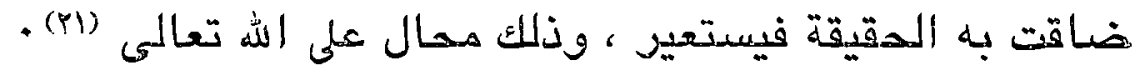

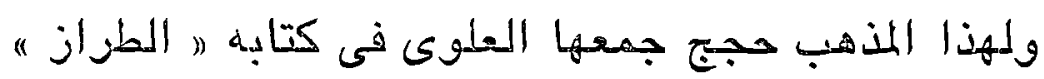

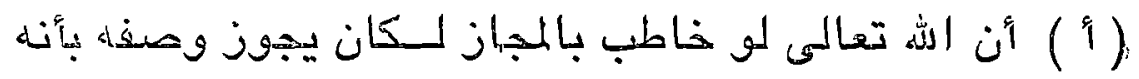

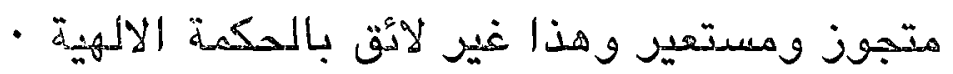

(اب) أنه لا فائدة فى العـدول الى المجاز مع امكان الحقيقة

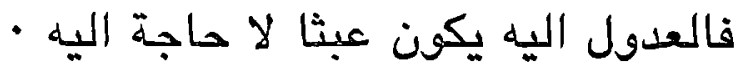

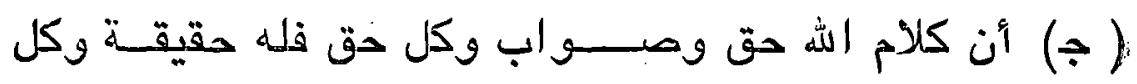

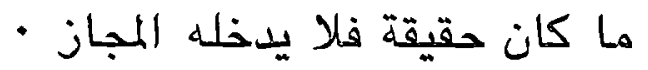

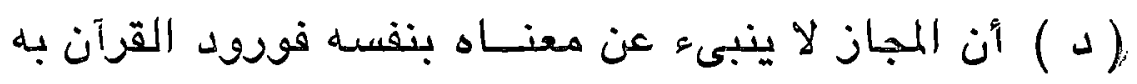

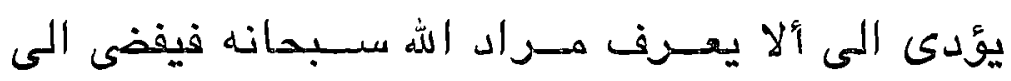
•الالباس وهو منزه الاس عنه (rr)

وقد عقب الزركثى على منع استعمال المجاز فى القرآن

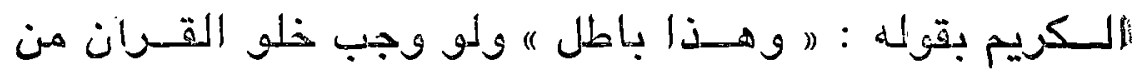

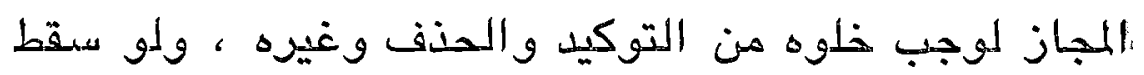

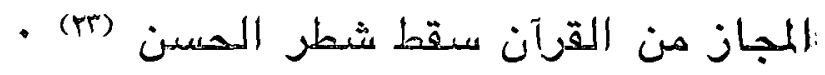

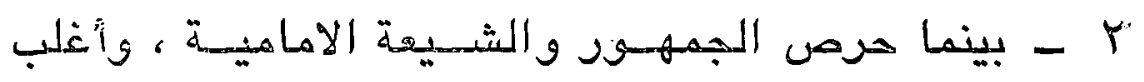

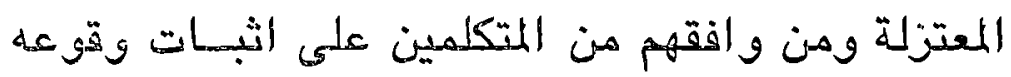

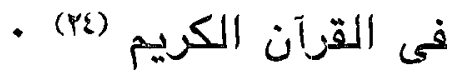

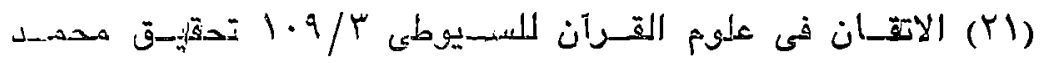

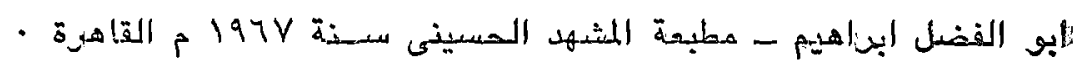

•

- roo/r البهان (Y)

( 


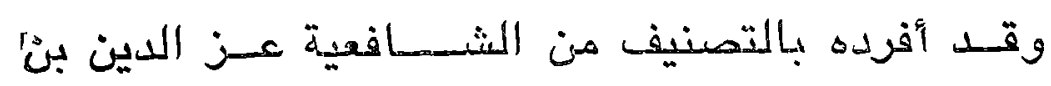

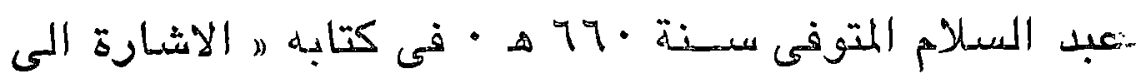

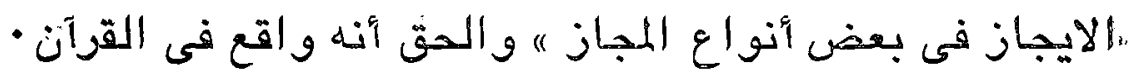

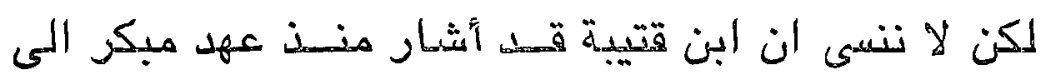

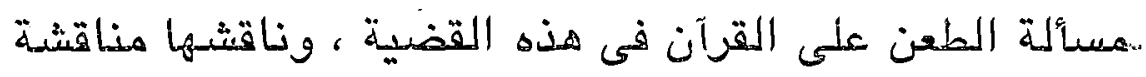

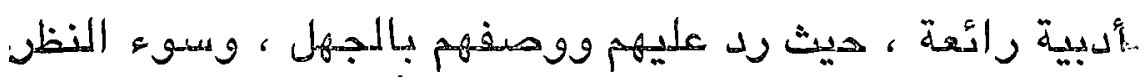

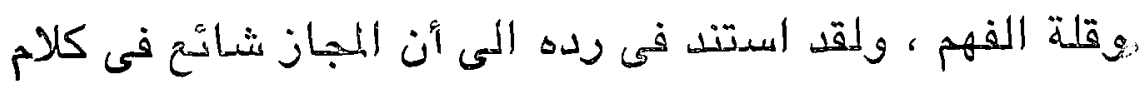

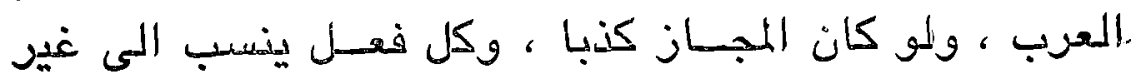

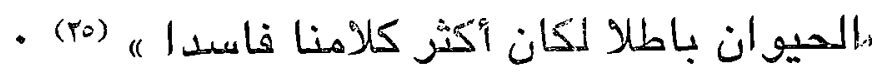

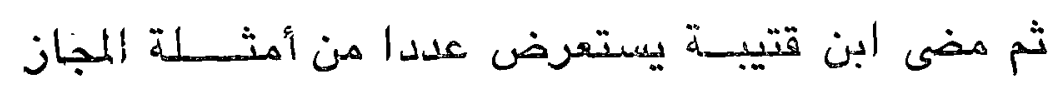

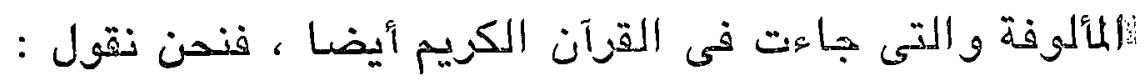

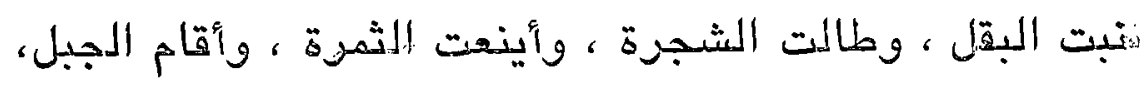

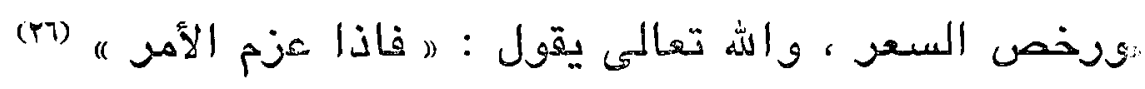

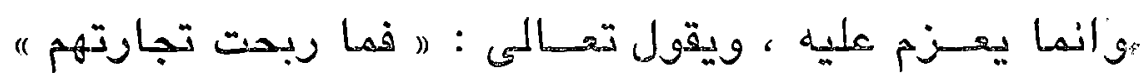

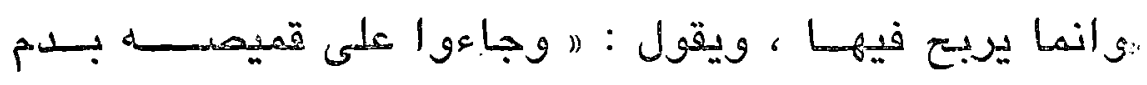

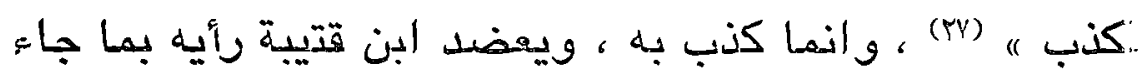

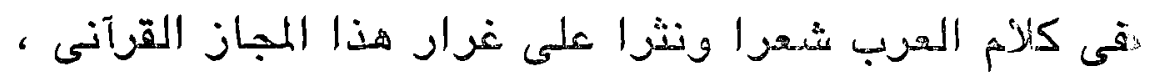

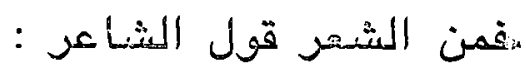

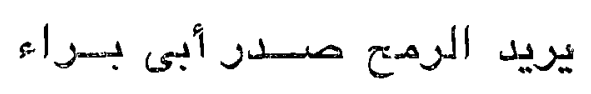

ويرغب عن دماء بنى عقديـل (1)

-

$$
\begin{aligned}
& \text { - }
\end{aligned}
$$

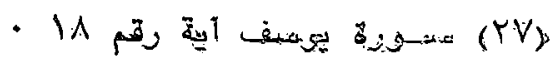

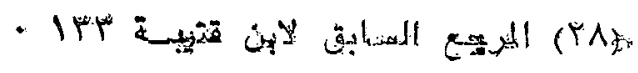




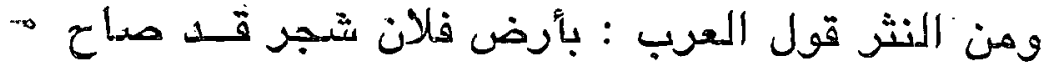

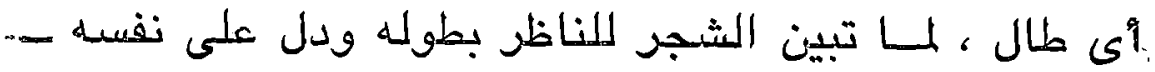

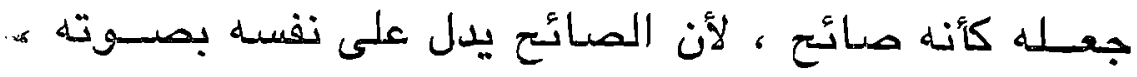

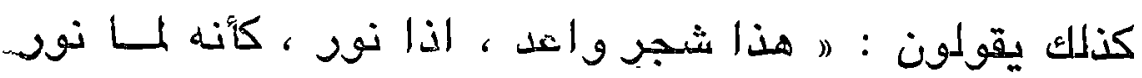

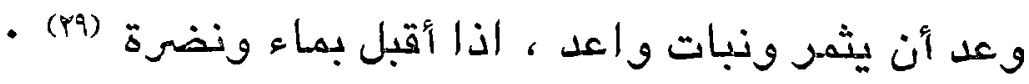

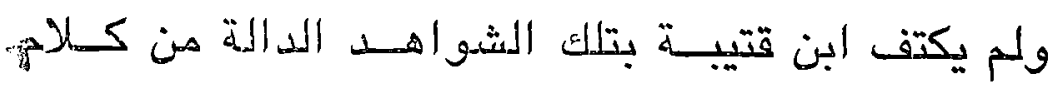
العرب ، فراح يحتكم الى هنطق العقل والذوق ، قائلا : بأننا

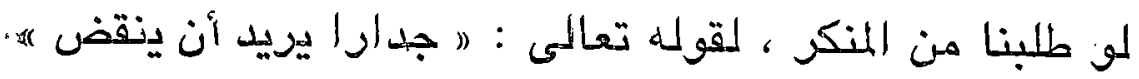

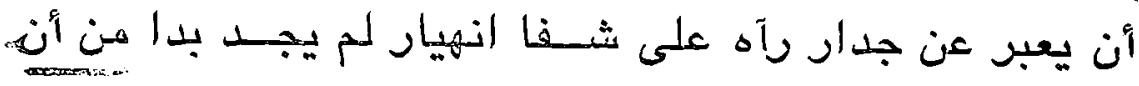

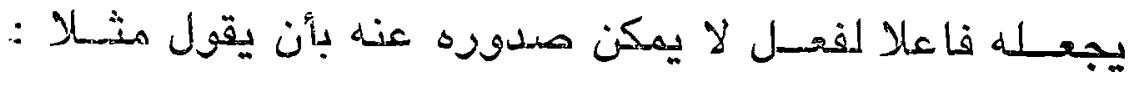

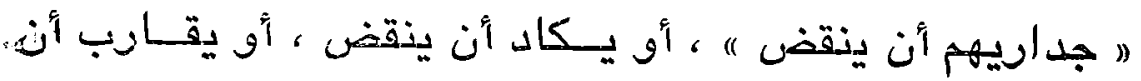

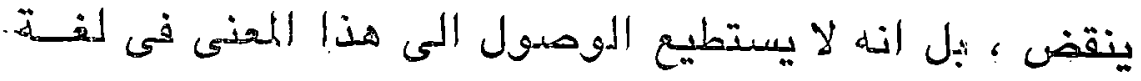

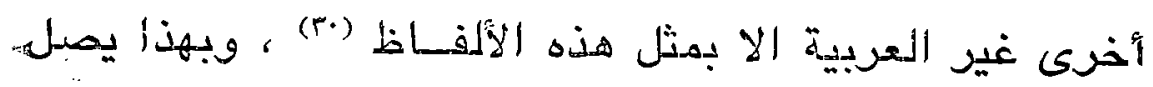

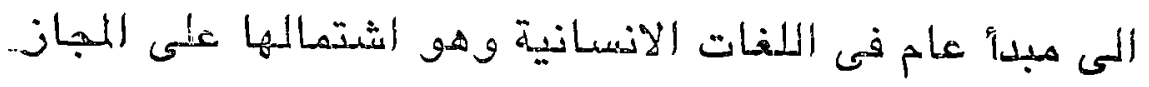

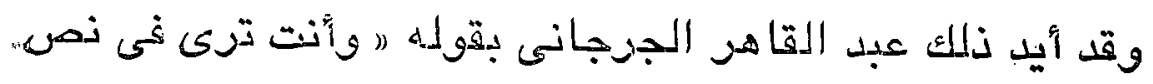

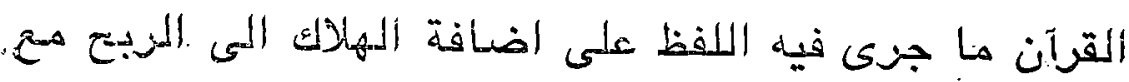

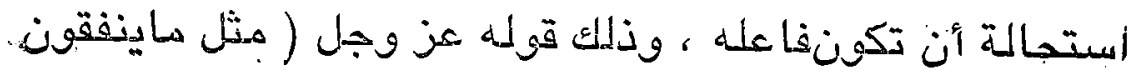

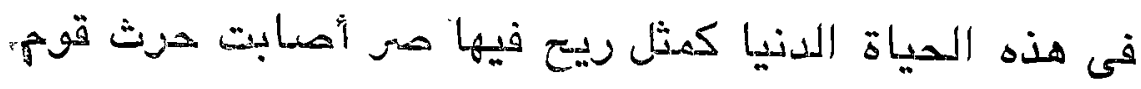

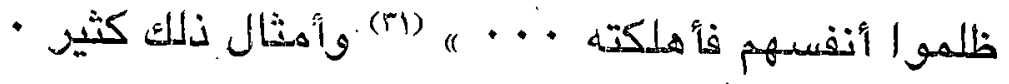

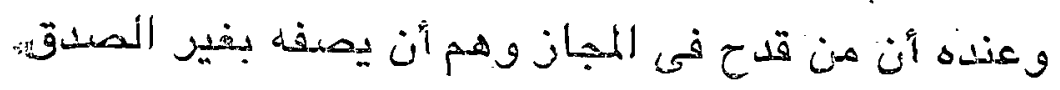


-

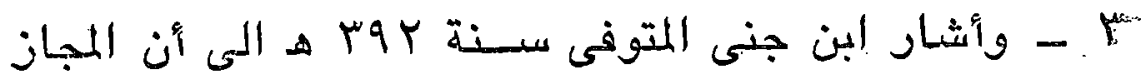

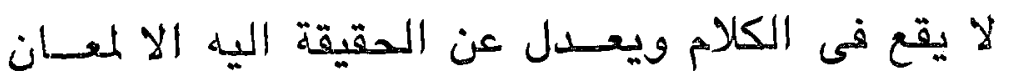

ثلاثة همى : الاتساع ، و والتوكيسد ، والتثـبييه · فان

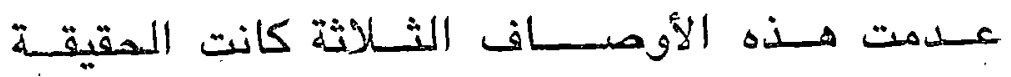

$$
\text { - (Tr) \& البتة }
$$

و لا نريد أن نناقش ابن جنى فى هذا الاتسـاع أو التوكيد

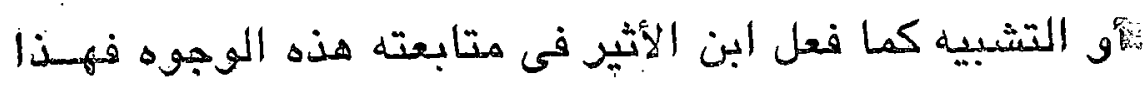

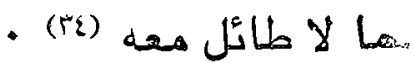

بل نقول : ان المجاز في قيمته الفنية لا يختلف عن المقيقة

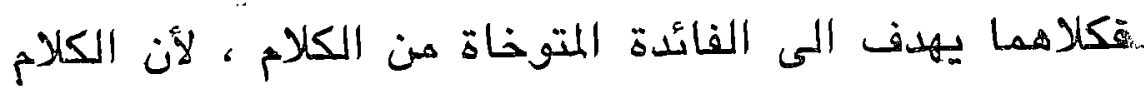

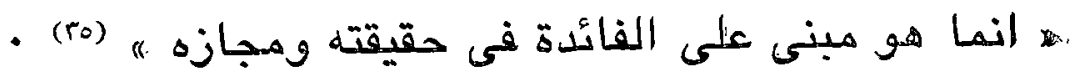

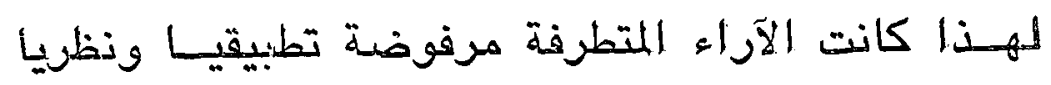

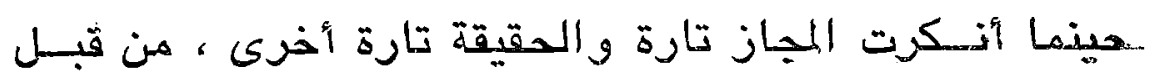

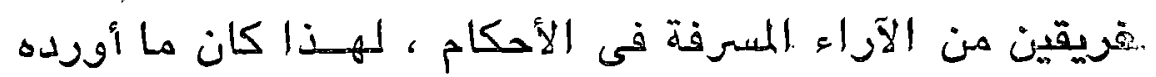

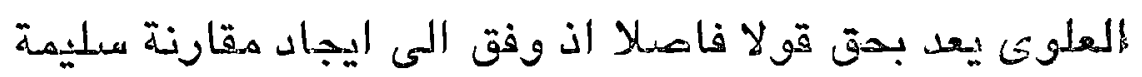
:

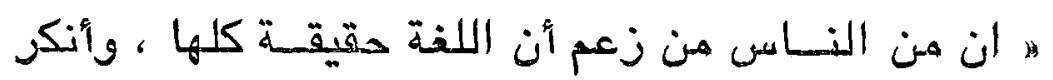

$$
\text { - (YT) }
$$

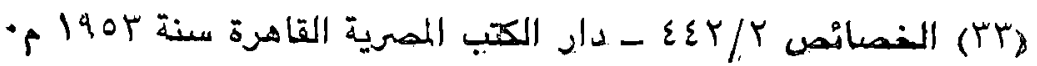

-

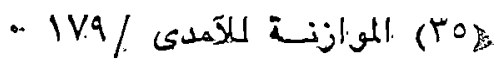




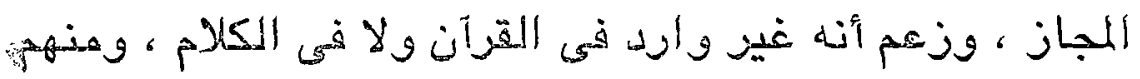

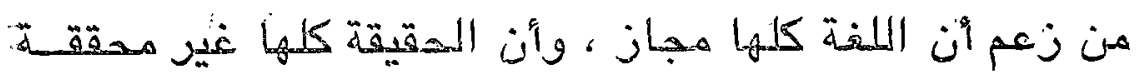

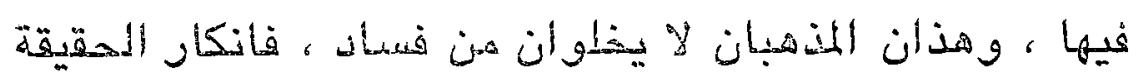

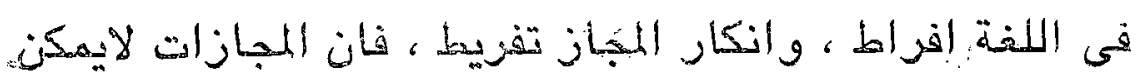

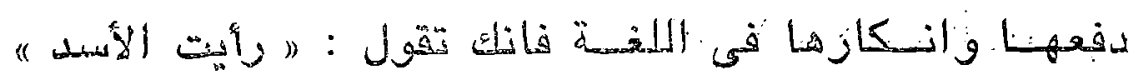

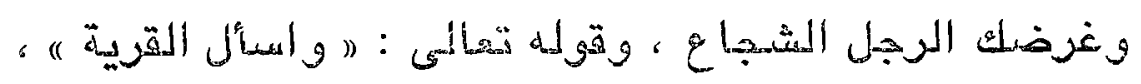

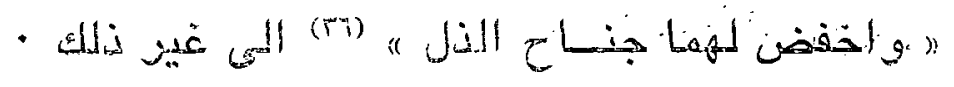

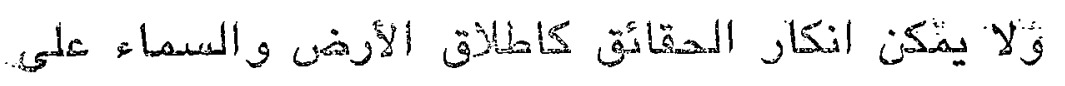

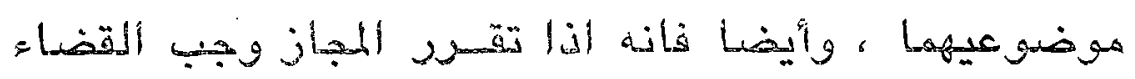

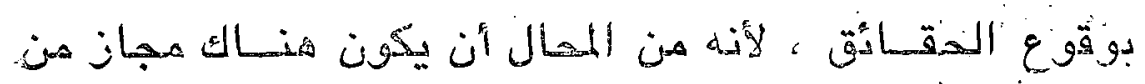

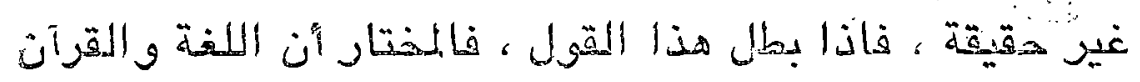

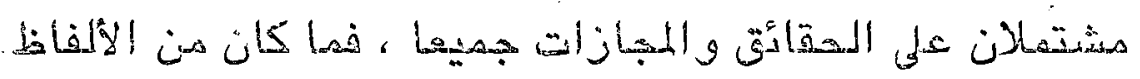

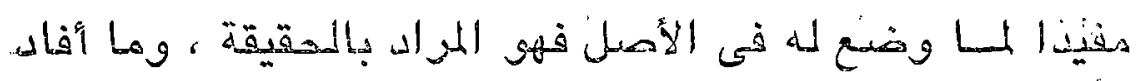

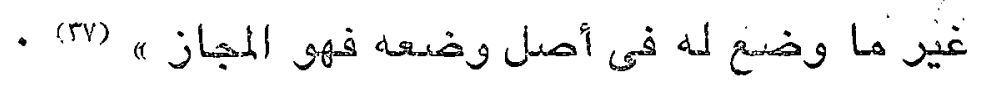

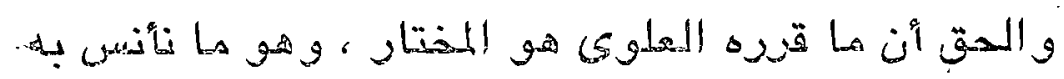

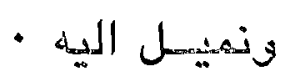

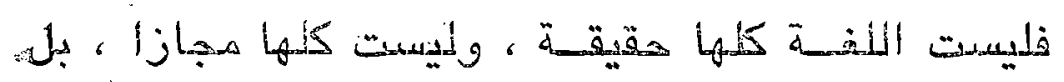

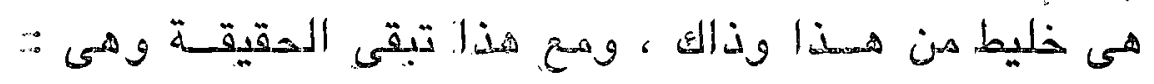

- $\varepsilon$ ع الطراز (rV)

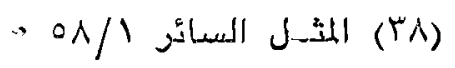




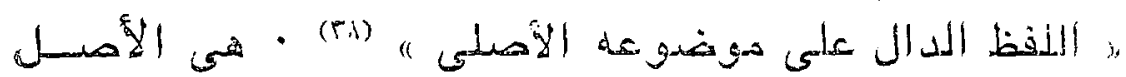

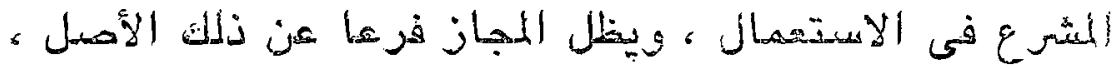

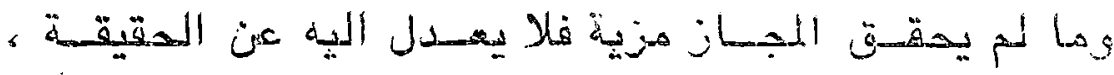

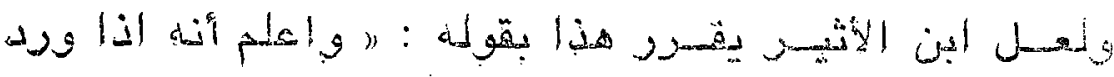

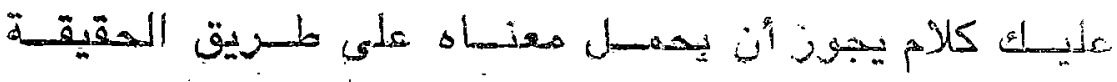

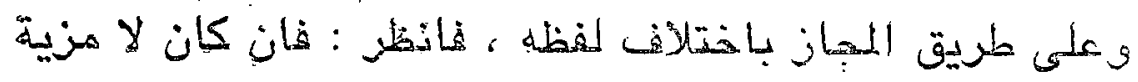

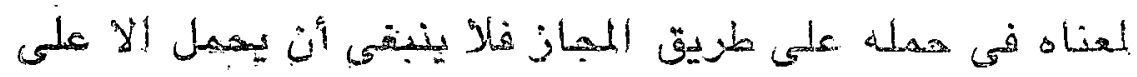

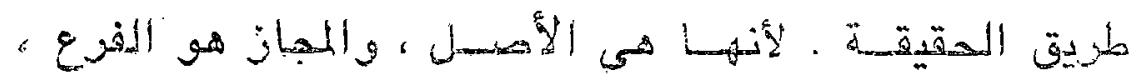

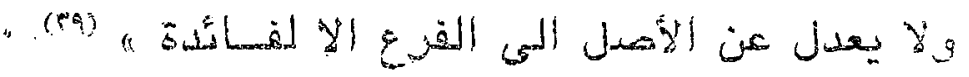

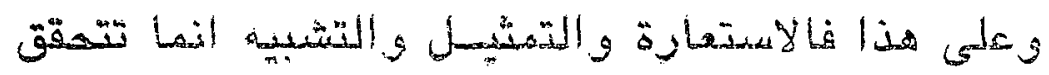

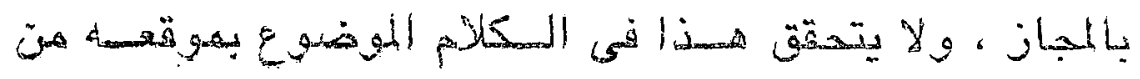

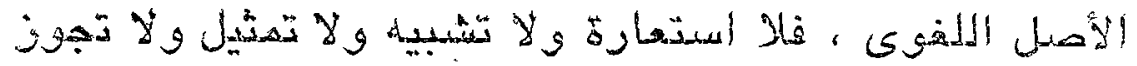

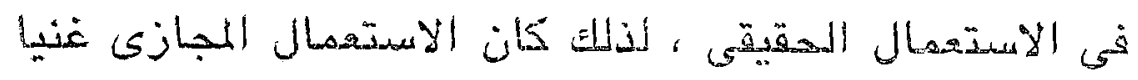

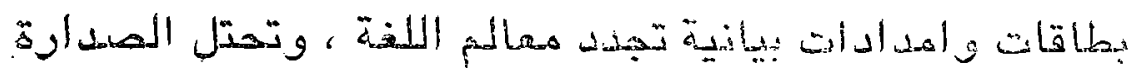

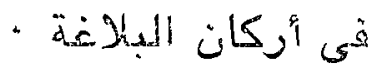




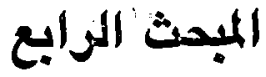

أقسام المجناز

\author{
ويتنــاول : \\ *

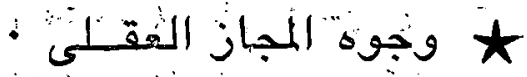 \\ *

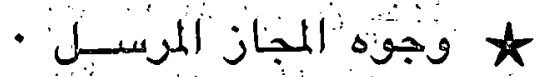

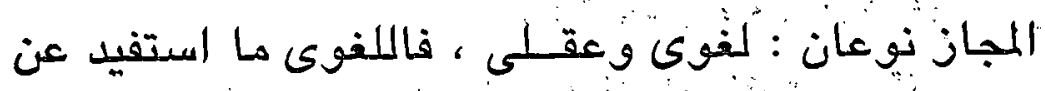

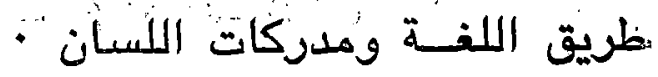

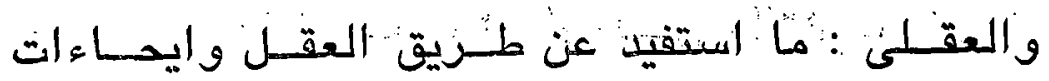
- البفطرة:

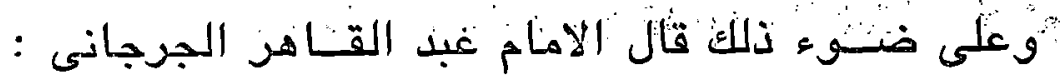

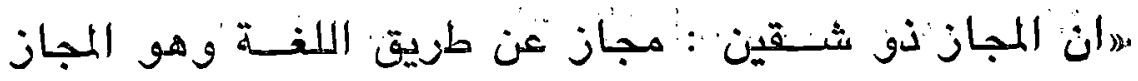

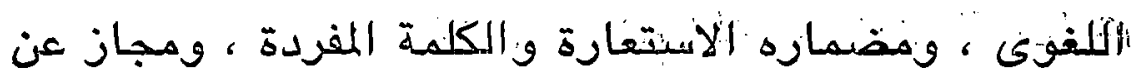

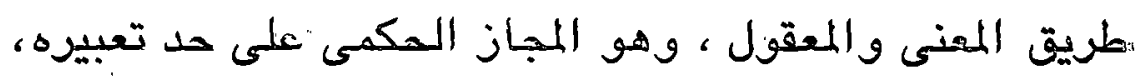

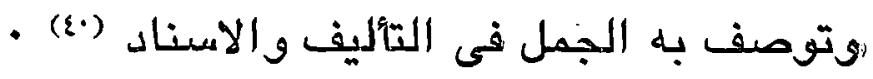

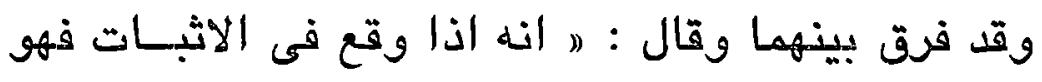

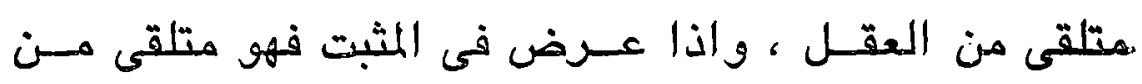

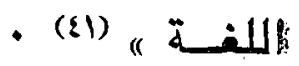
وكل من المجــازين اللغــوى والعقـلى لا يدرك الا فى

- rVY/ ع (ع) السوار البلاغة

- المصدر نفسه ع (1) 


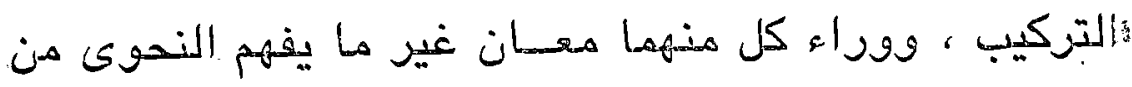

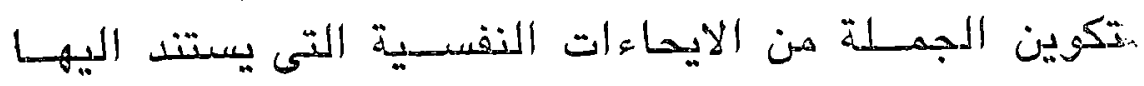

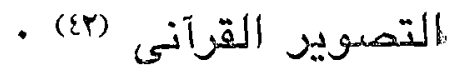

و هذا التقسيم لم يكن معروفا بدقته هذه ، بل بل كان المجاز

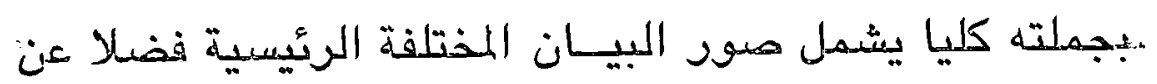

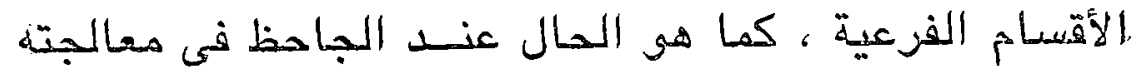

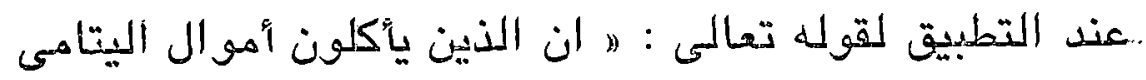

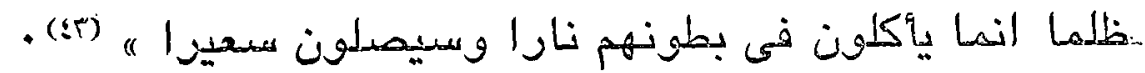
يعدها من باب المجاز و التشبيه علنى شئكلة هوله تعالى :

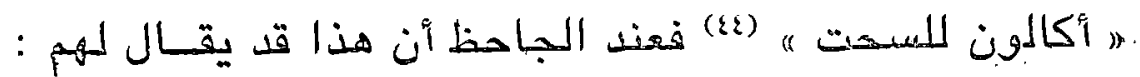

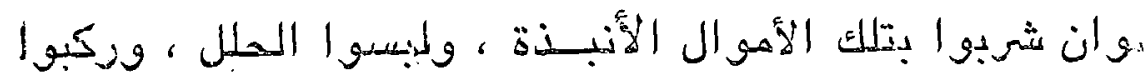

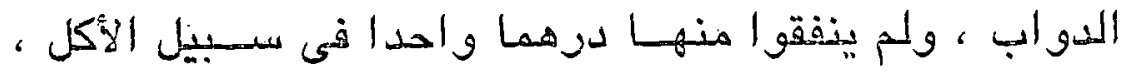

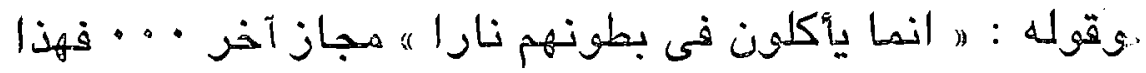

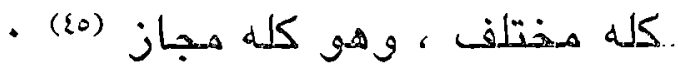

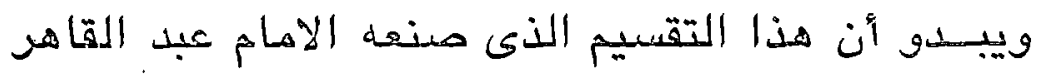

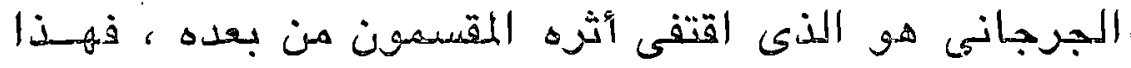

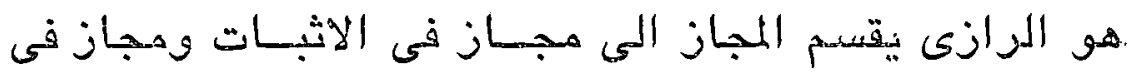

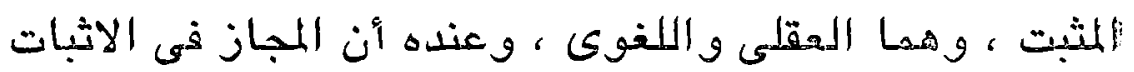

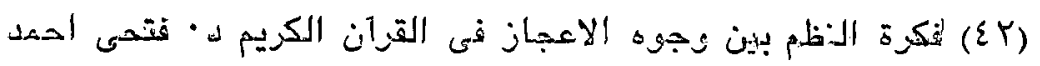

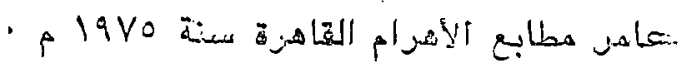

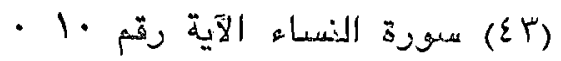

•

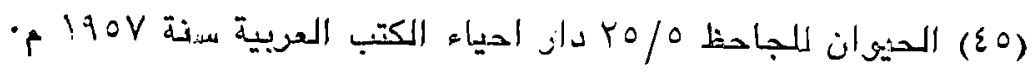




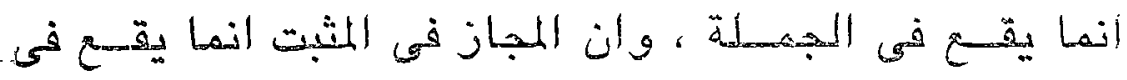
(21) المفيزرد)

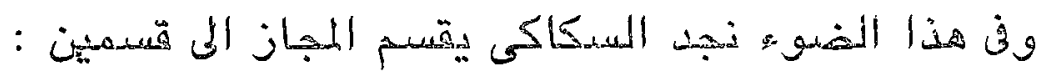

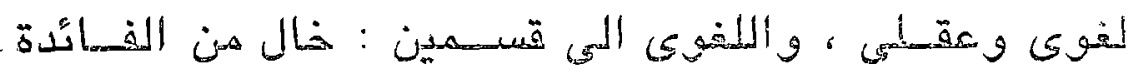

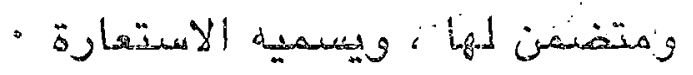

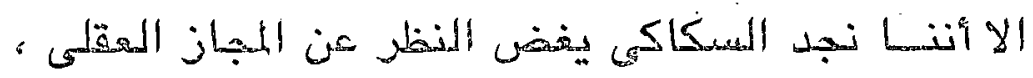

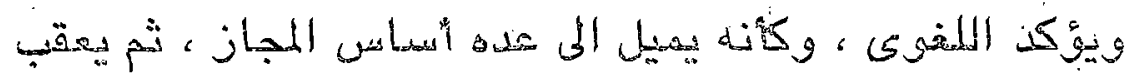

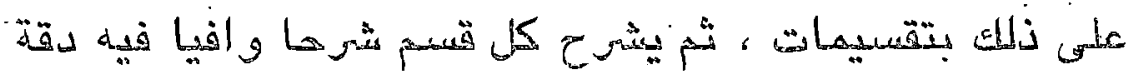

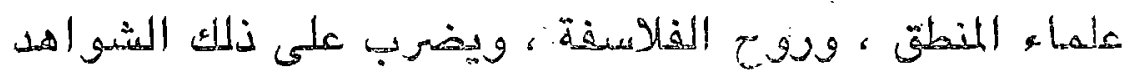

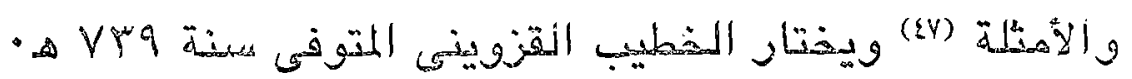

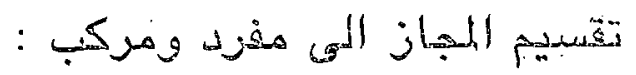

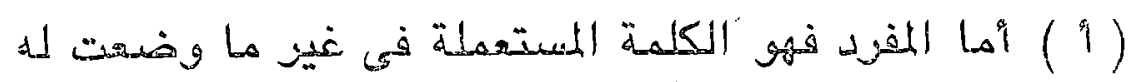

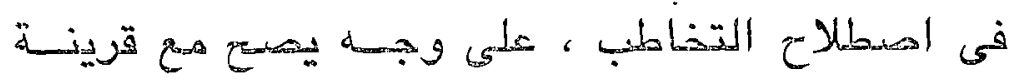

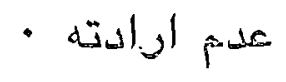

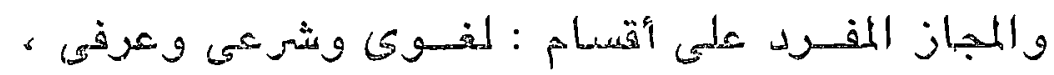

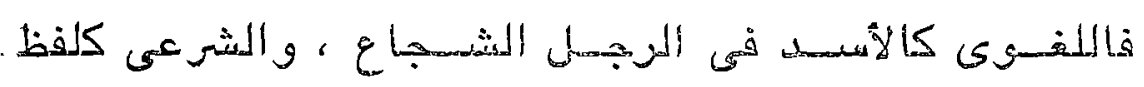

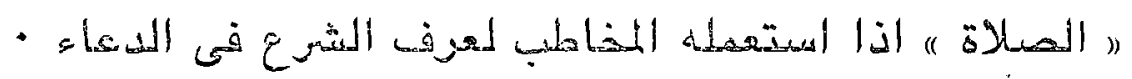

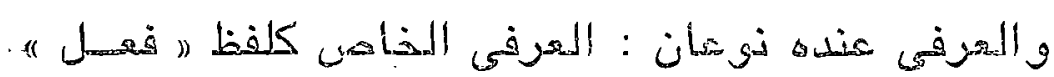

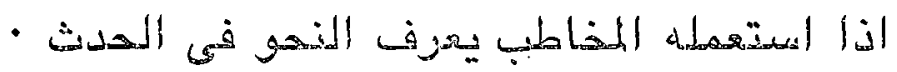

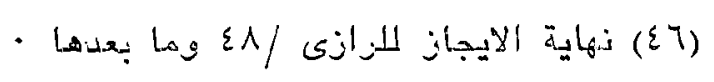

(EV) 


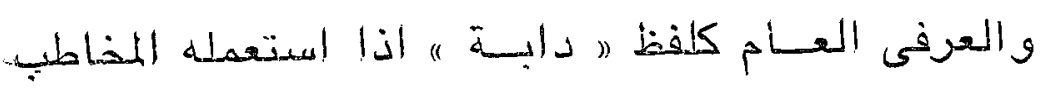

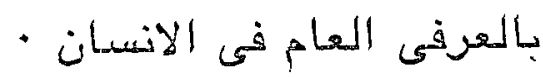

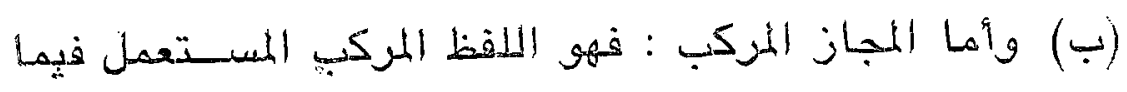

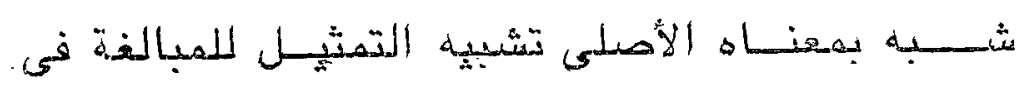
التشبيد

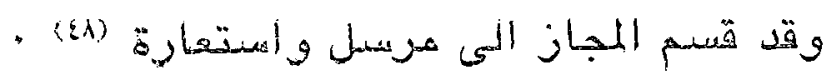

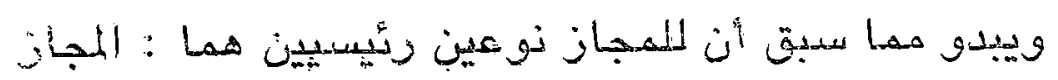

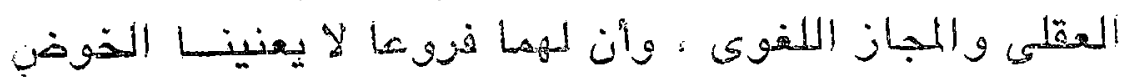

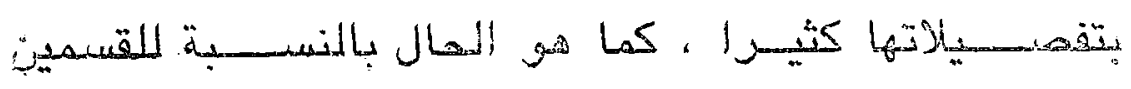

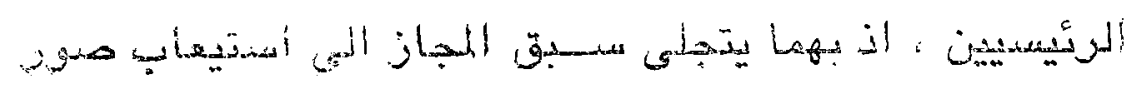
- لديـان

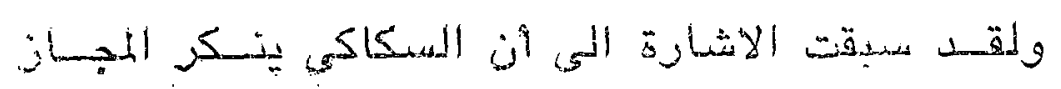

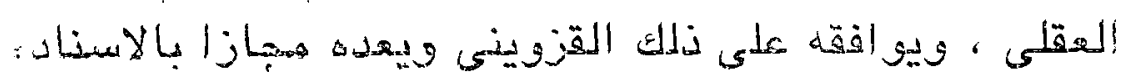

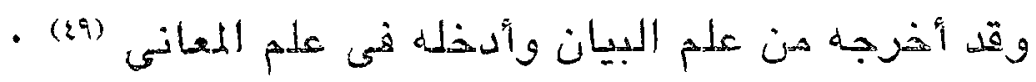

وقد أنسكره هـاحب الطراز هيث قال : " و المختسار أنه.

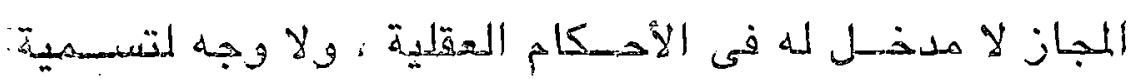

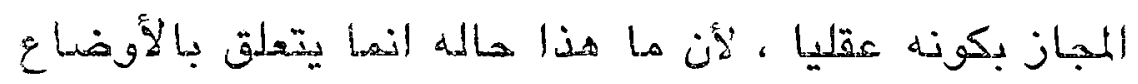

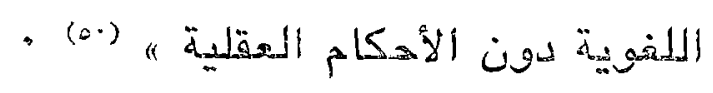

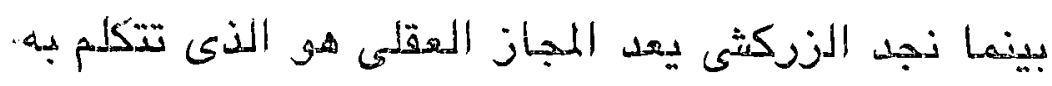

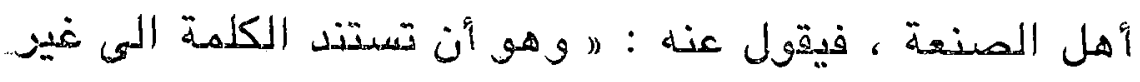

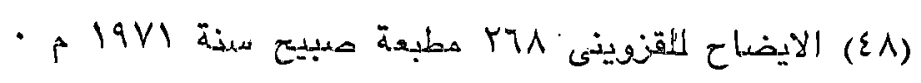

$$
\text { - ry/ }
$$

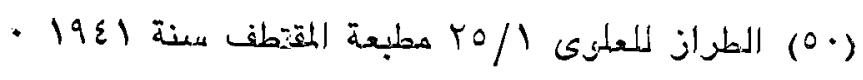




$$
-r \varepsilon \wedge .
$$

ما هي له أصالة لضربب من التأول ، هو الذى يتكلم فيه أهل

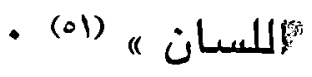

غير أننــا نجد القرآن الكريم ـ وهو أرقى ما يتكلم بـهن

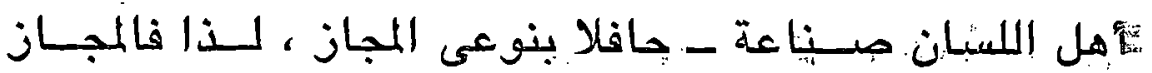

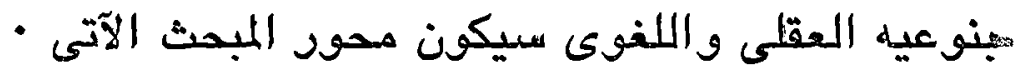

$\star \star \star$

- roy/r/لبرهان (01) 


\section{المجاز العقدملي)}

وهو المجاز الذى نتوصـل اليه بحكم العقـل ، غيثيسر.

الاحسـاس بطريقة استدمهاله ويهز الشعور بنتسائيج ارأدته ك.

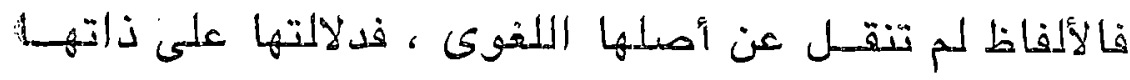

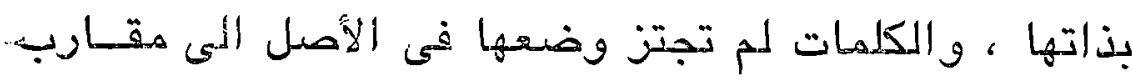
له أو مشابه ، وانما يستشعر بهذا المجاز عن طريق التركيب.

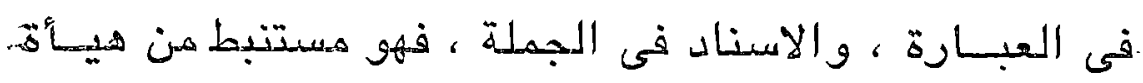

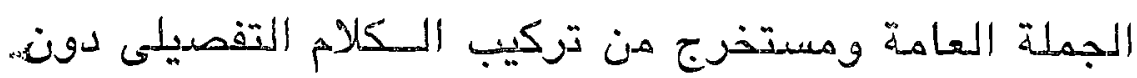

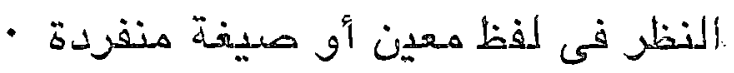

ومن خلال هذا المنظور المتطور تبـدو طريقة الأستعماله.

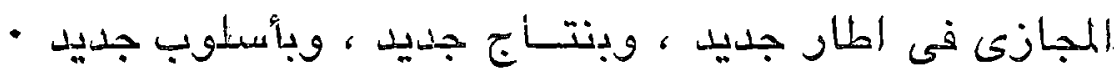

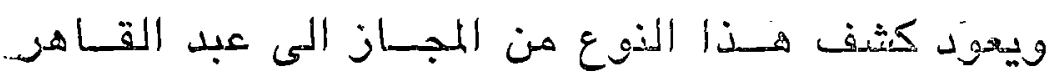

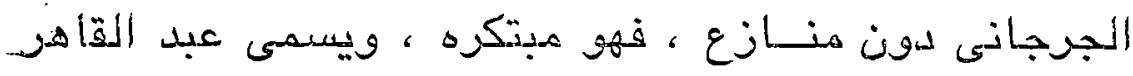

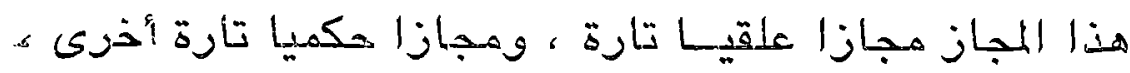

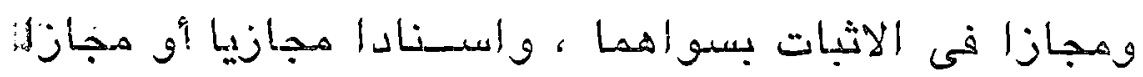

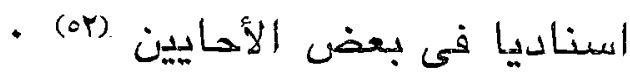
وقد نبـه هـاهب المراز المى فـكرة ابتكاره وتسميتيه ه.

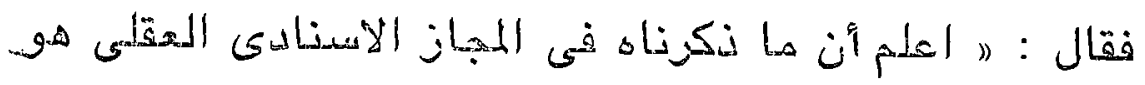

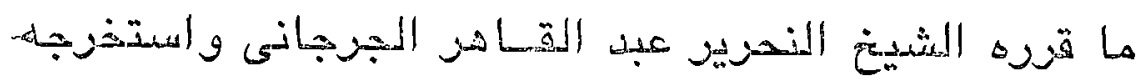

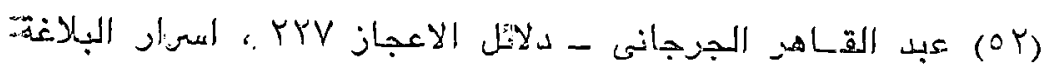




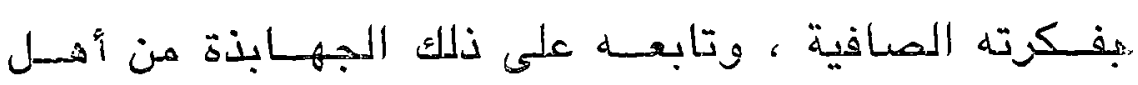

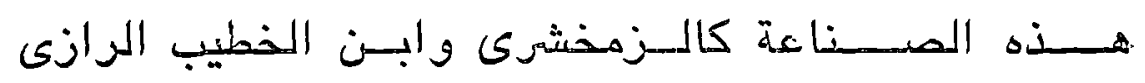

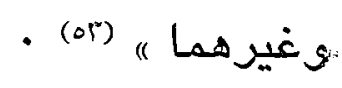

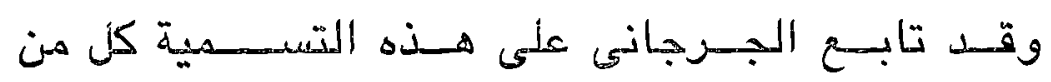

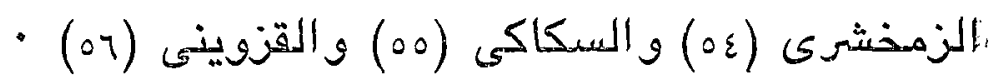

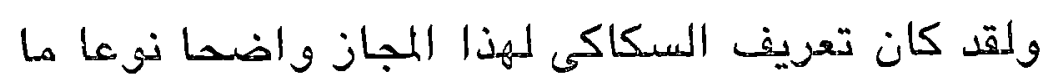

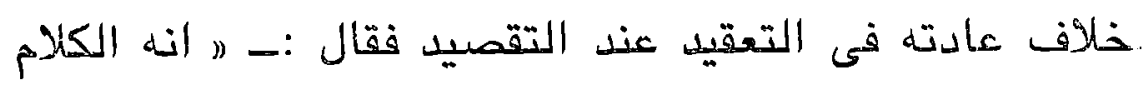

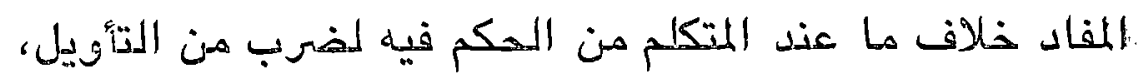

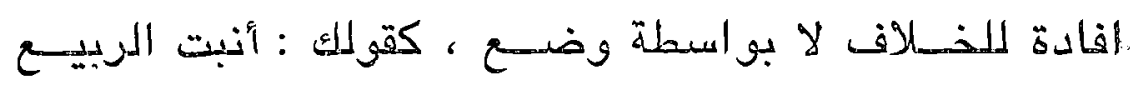

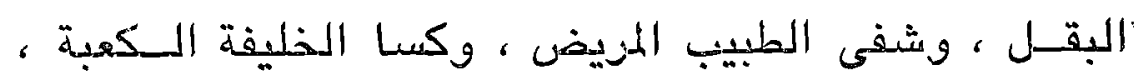

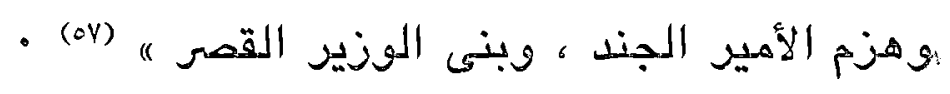
و الدق أن السكاكى لم يزله شيئا عما حققه عبد القاشر

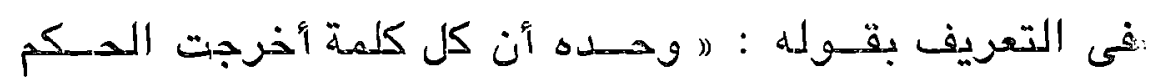

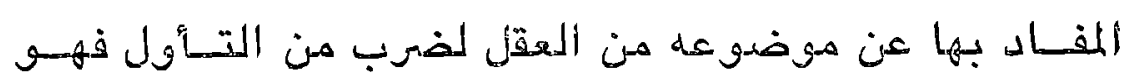

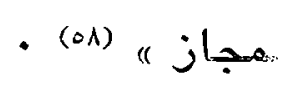

وما دام الاهمام عبد القاهر الجزجانيى هو السباق لهــذا

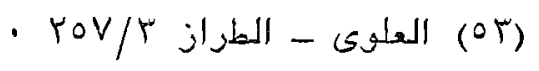

$$
\begin{aligned}
& \text { - ع } 00 / r \text { r }
\end{aligned}
$$

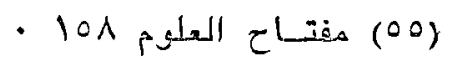

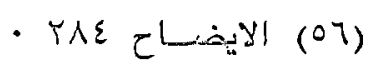

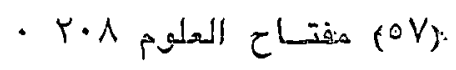

$$
\begin{aligned}
& \text { - ror/ / (O.人). }
\end{aligned}
$$




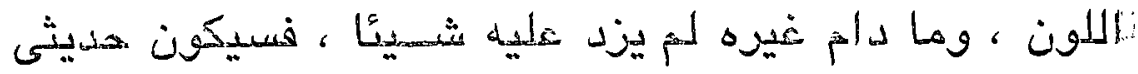

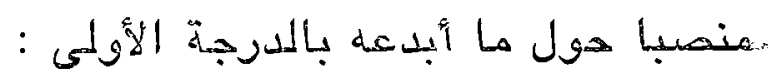

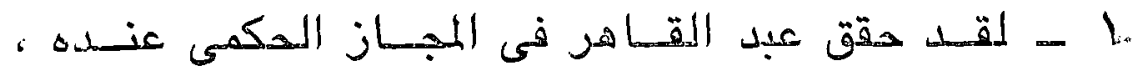

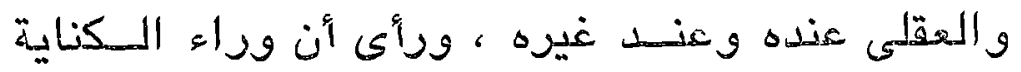

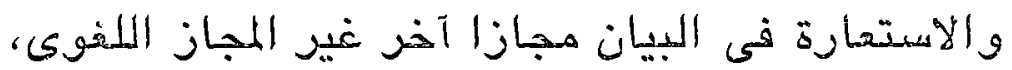

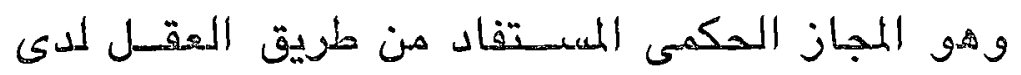

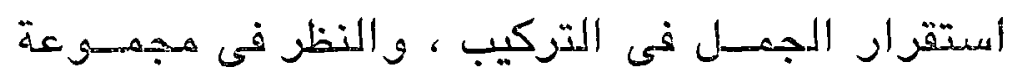

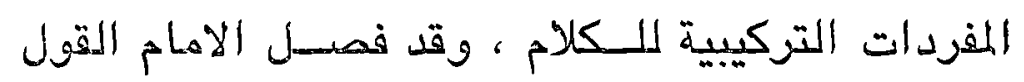

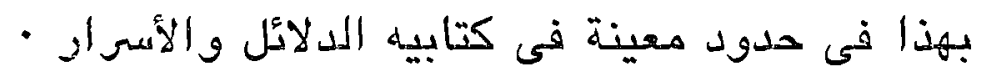

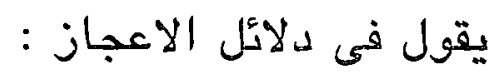

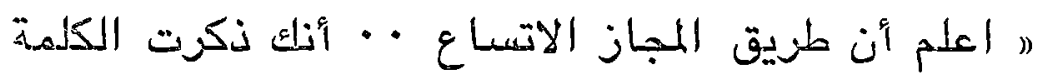

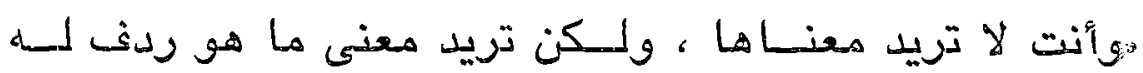

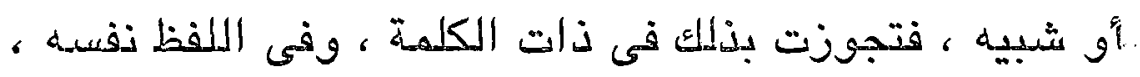

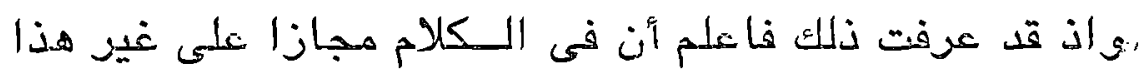

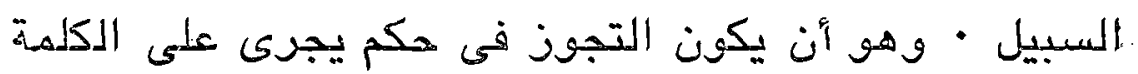

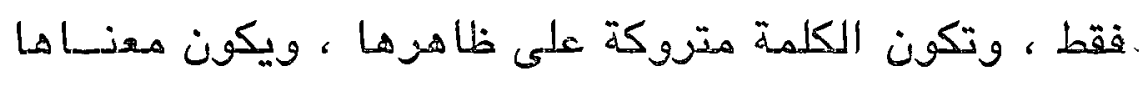

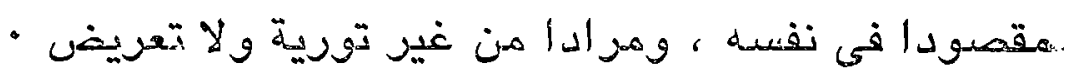

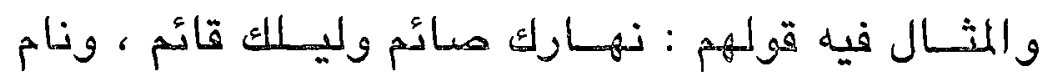

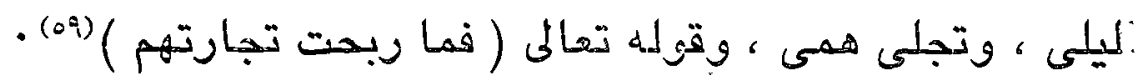

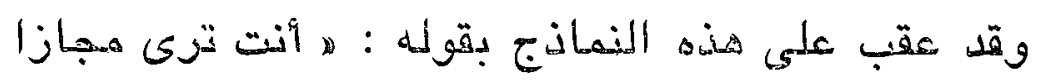

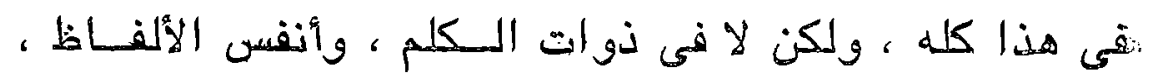


ولـكن فى أحكام أجريت عليها أفلا ترى أنك لم تتجوز فيه،

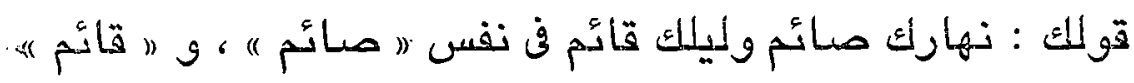
ولكن فى أن أجزيتهما خبرين على الليل والنهار ، كذلك ليسن.

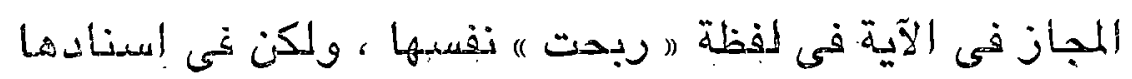

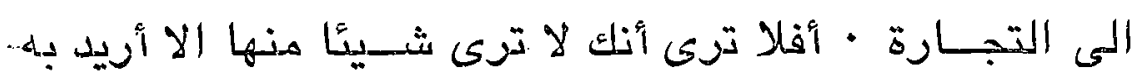

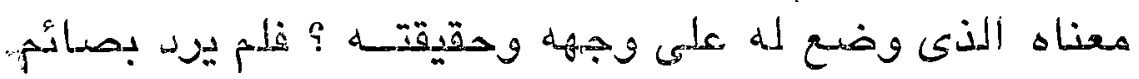

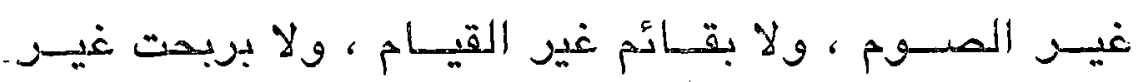

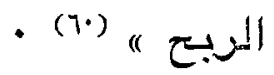

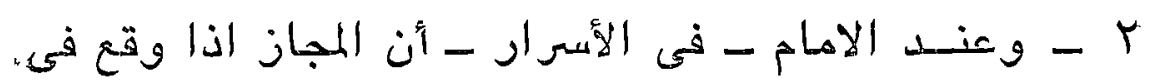

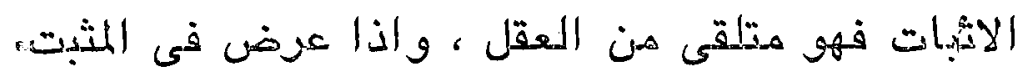

\section{فهو متّلى من اللفة (11)}

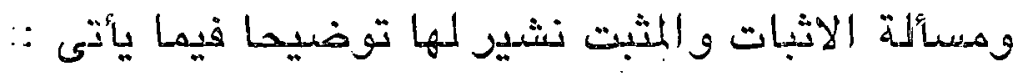

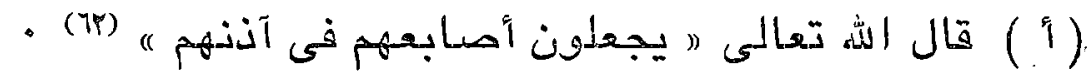

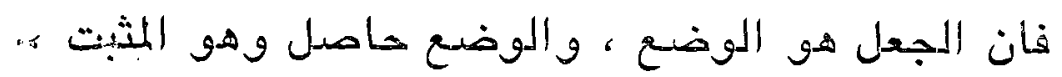

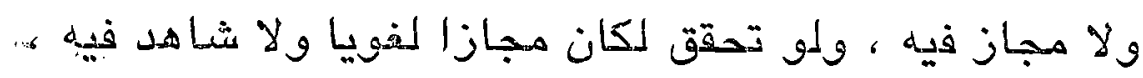

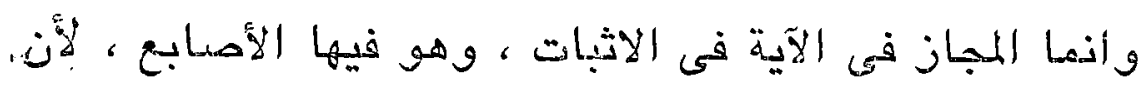

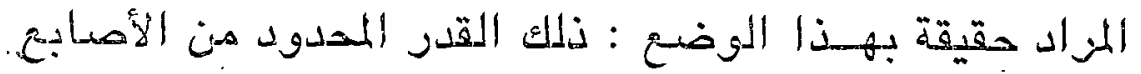

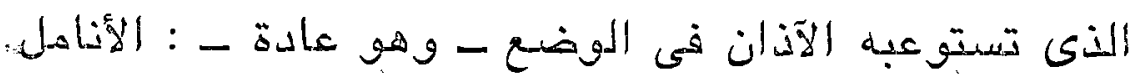

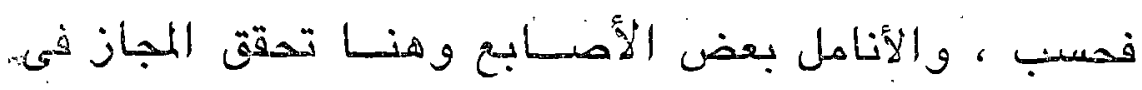

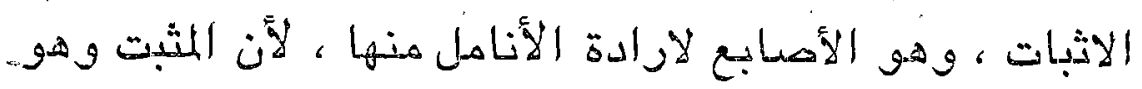

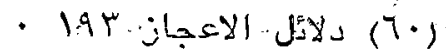

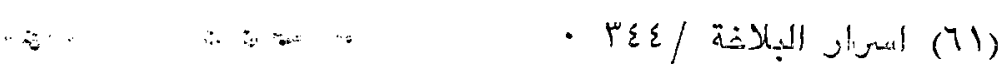

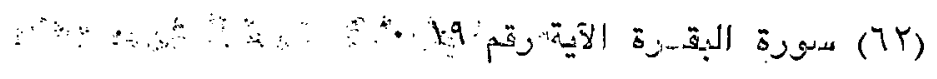


أصل الوضع حاصل على حقيقته

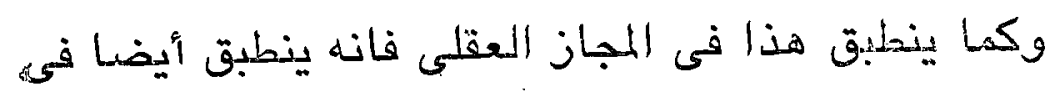

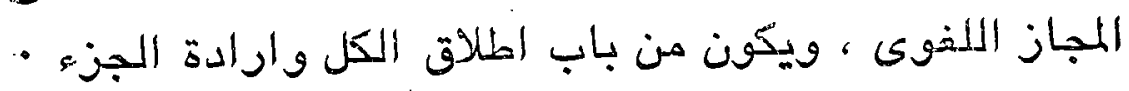

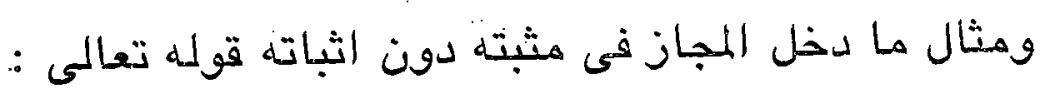

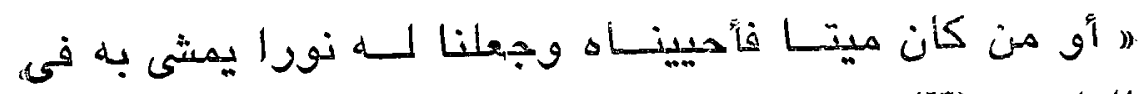

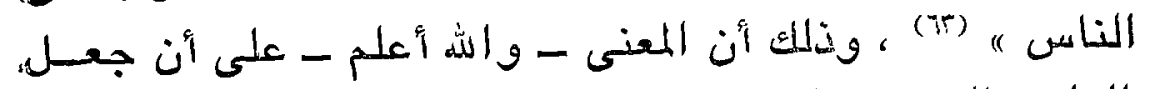

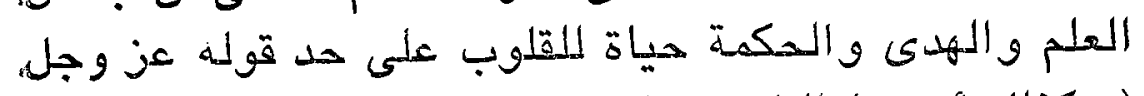

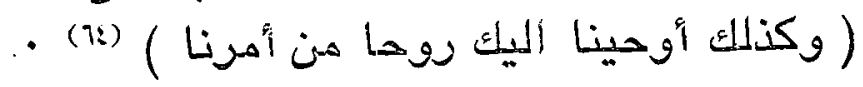

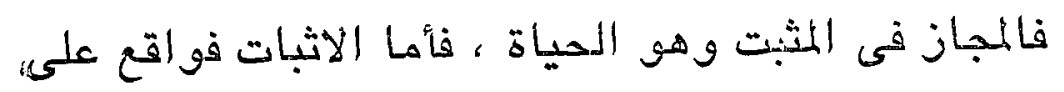

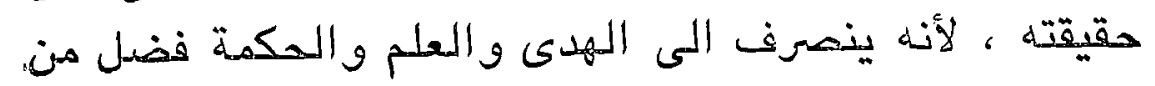

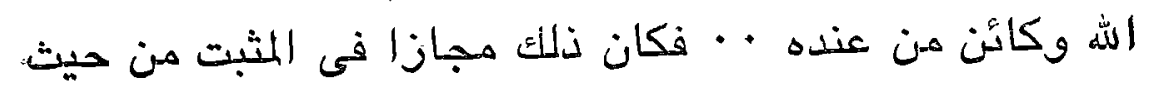

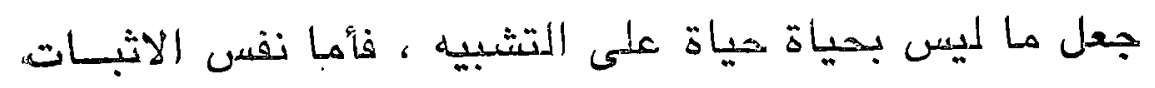

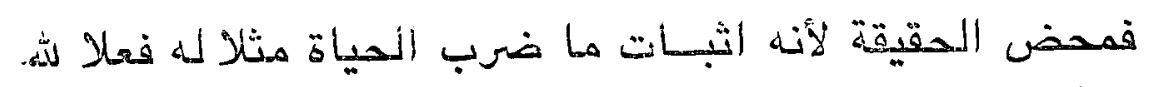

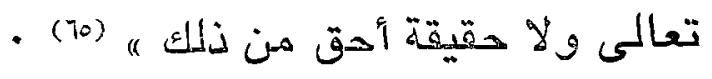

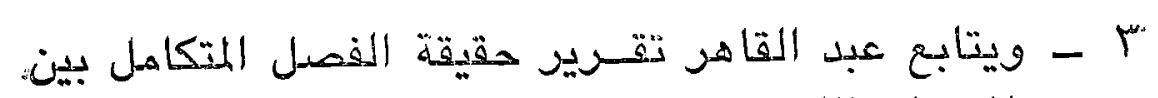

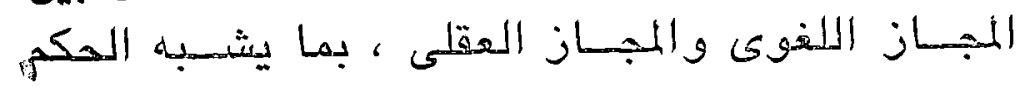

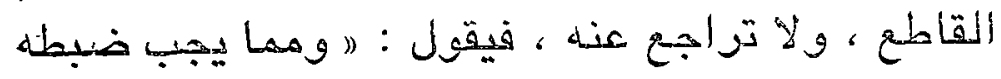

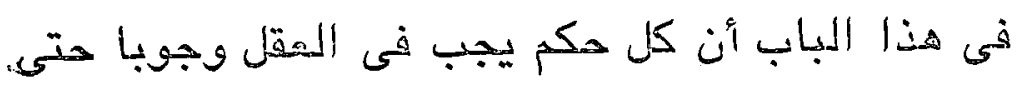

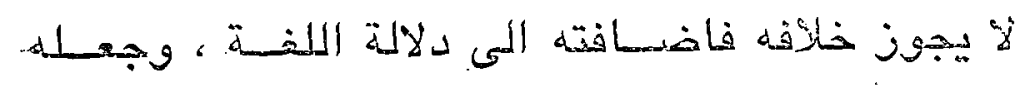

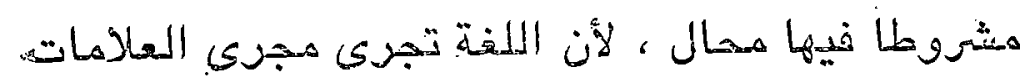

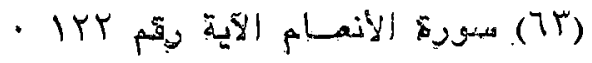

$$
\begin{aligned}
& \text { - or }
\end{aligned}
$$

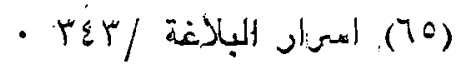

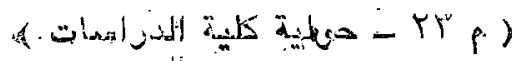




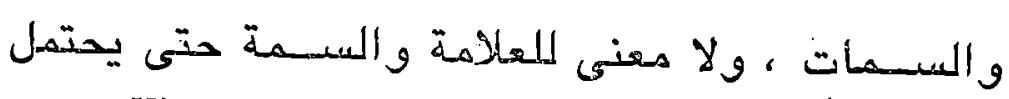

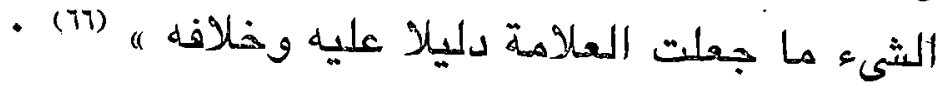

ع - وفى ضوء هذا الفهم للمجباز المكمى عند عبد القاهر

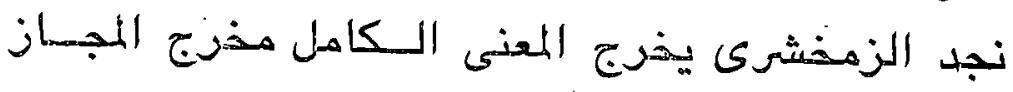

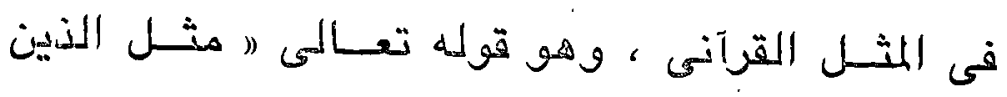

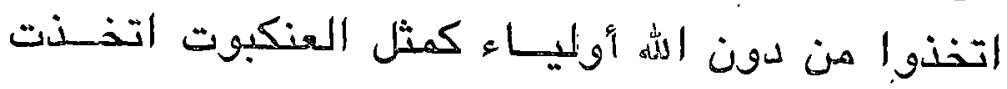

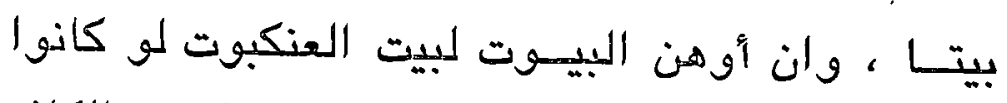

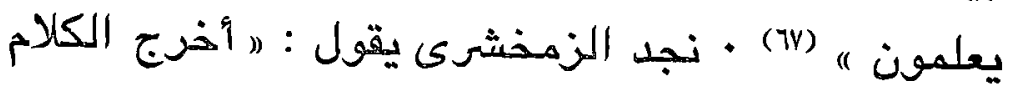

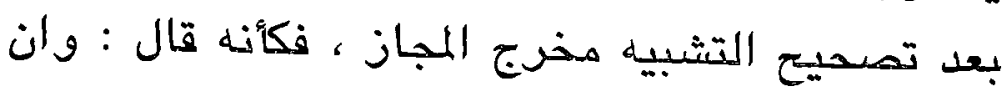

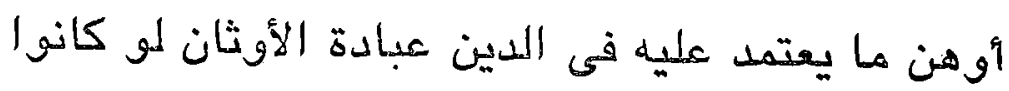

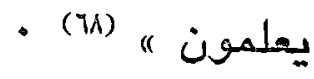

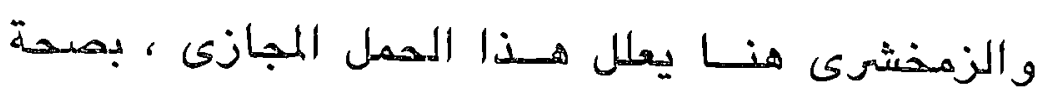

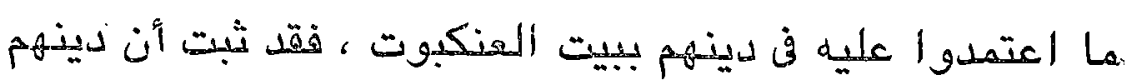

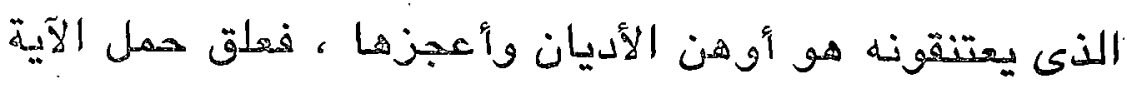

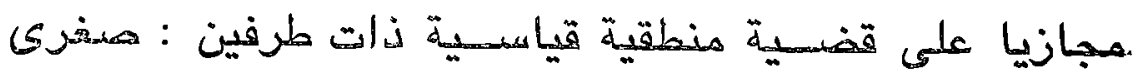

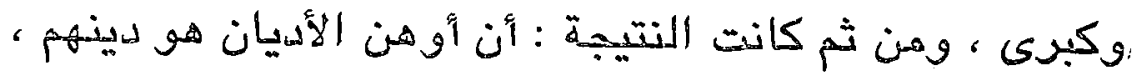

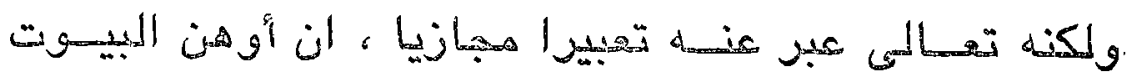

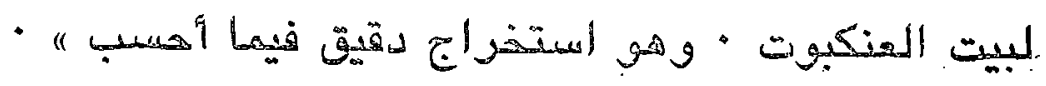

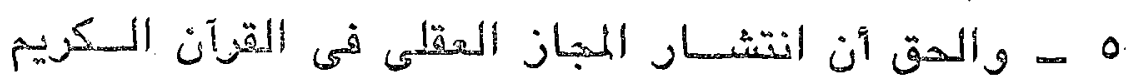

•

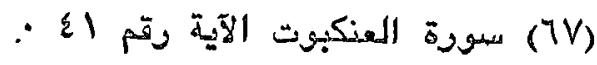

- 
يوهى بأصــالة استعماله البـلاغى فى نص هو أرقى النى

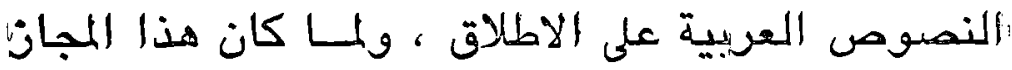

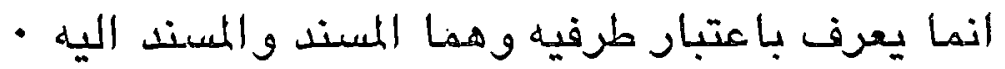

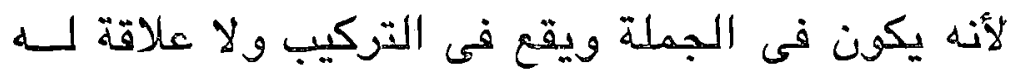

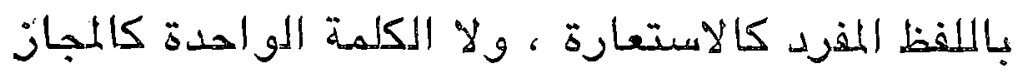

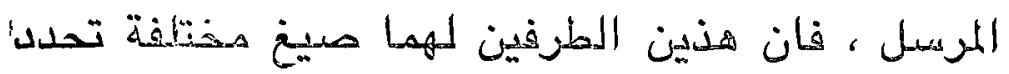

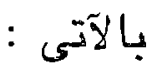

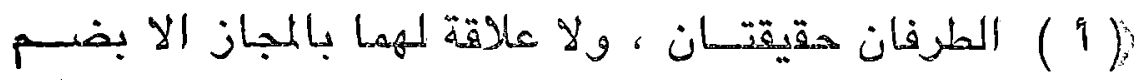

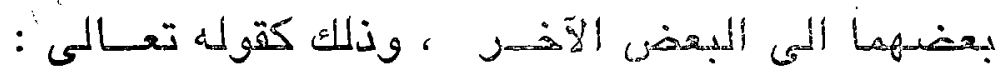

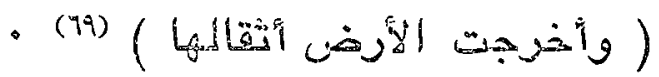

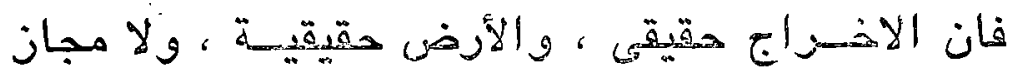

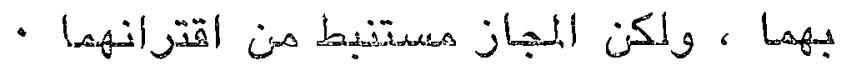

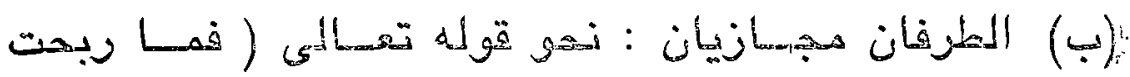

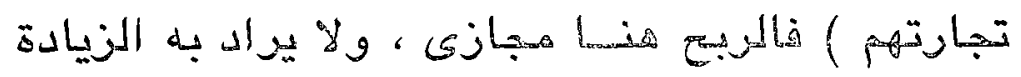

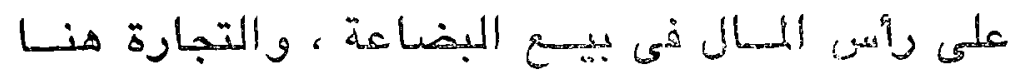

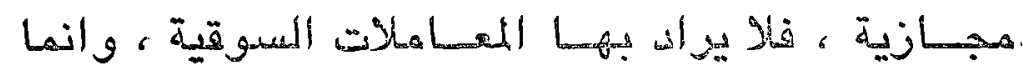

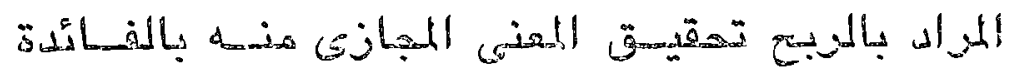

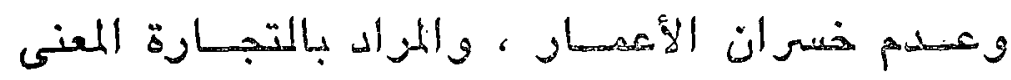

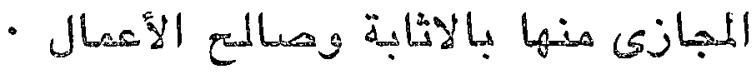

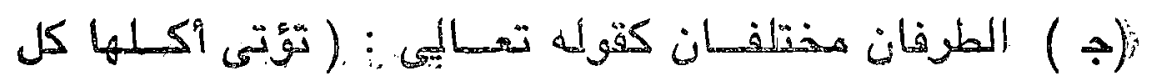




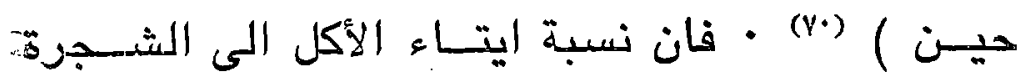

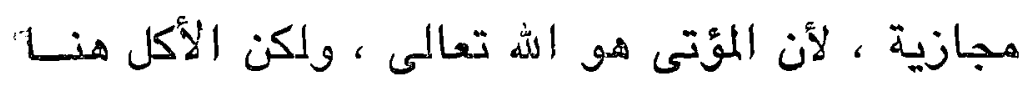

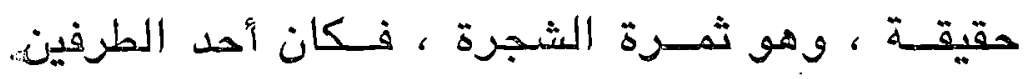

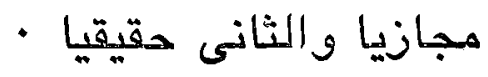

? - ومن البـديهى أن نلمس فى المجاز الحقلى ، وان كان.

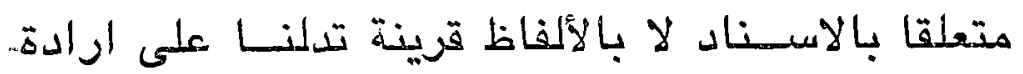

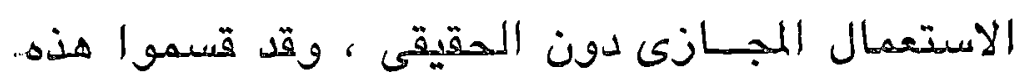

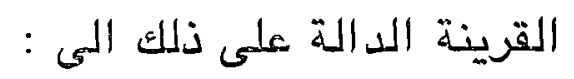

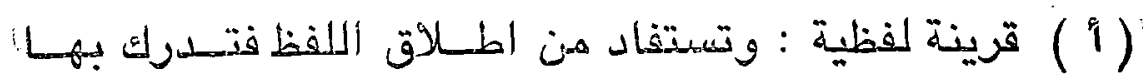

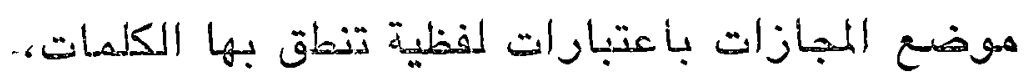

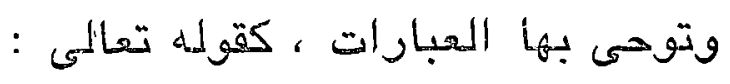

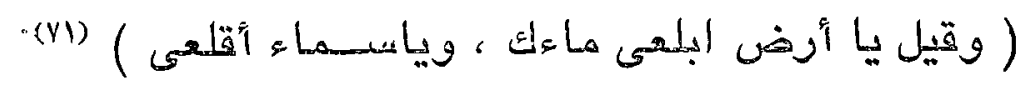

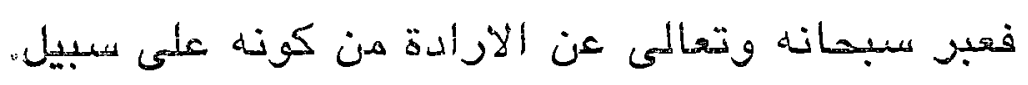

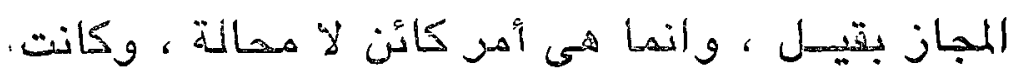

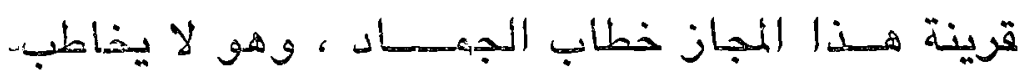

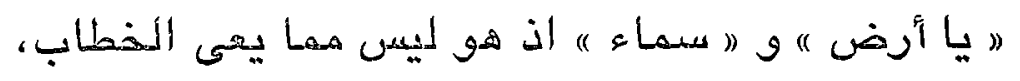

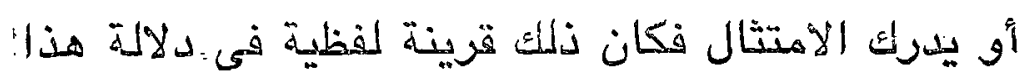
- المجاز العقلى ليلى الاهنتان

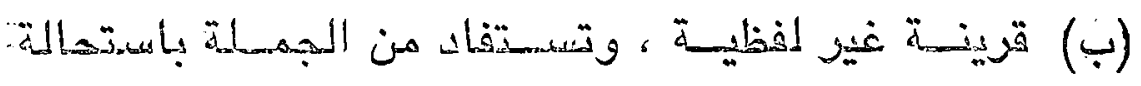

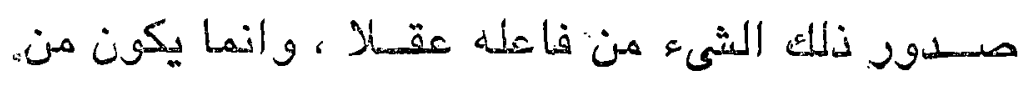

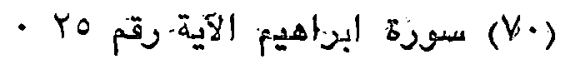

$$
\begin{aligned}
& \text { - }
\end{aligned}
$$




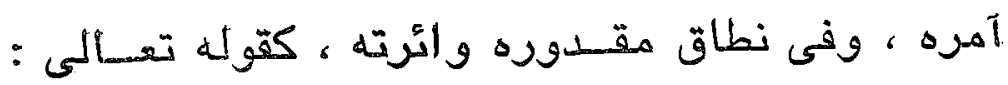

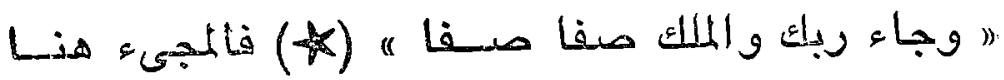

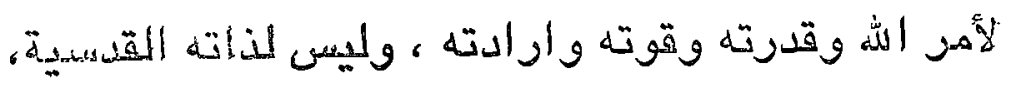

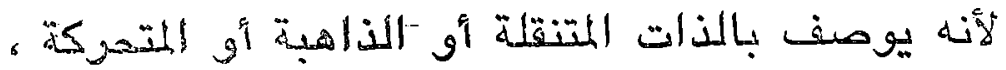
تعالى عن ذلك علوا كبيرا وما أستتفيد هنا لم يكن بقرينة لفظية هقالية ، بـل بقرينة

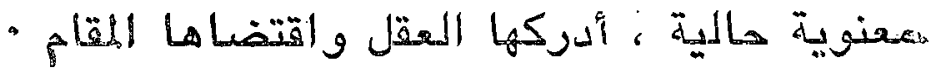




\section{وجوه المجاز العقلى}

تفنن علماء البلاغة العربية ، بابراز عبلاقات هذا المجاز

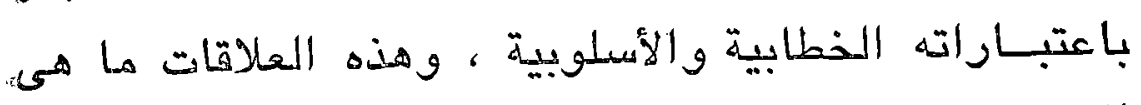

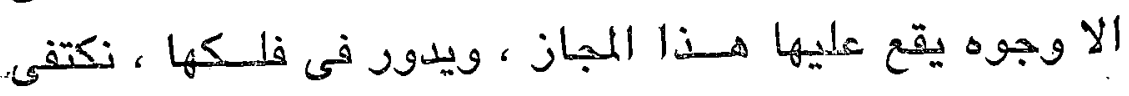

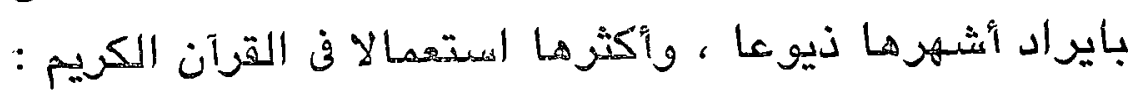

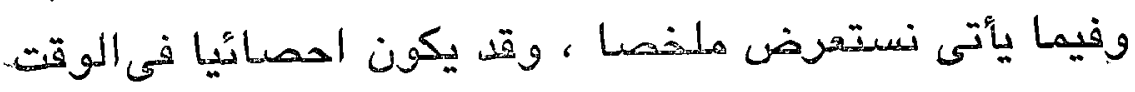

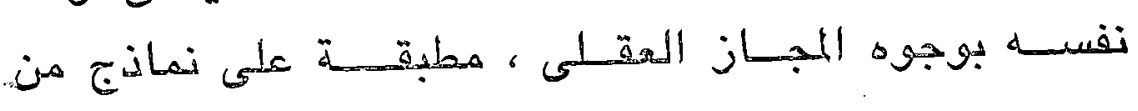
كتاب الله

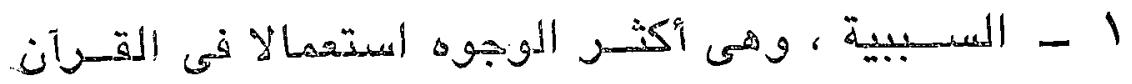

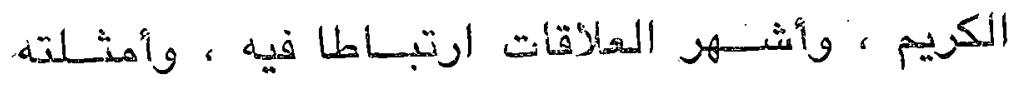

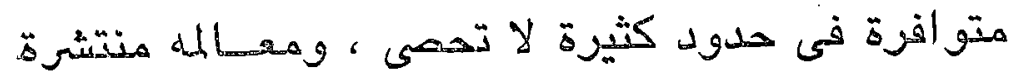

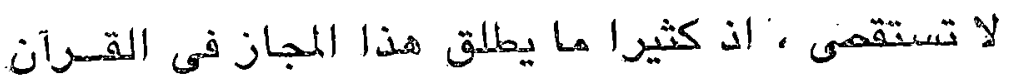

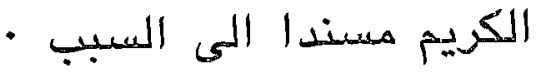

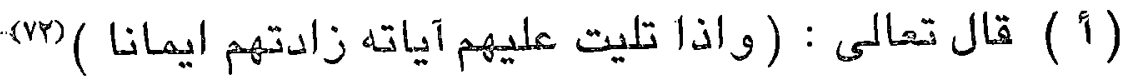

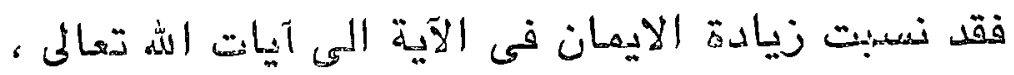

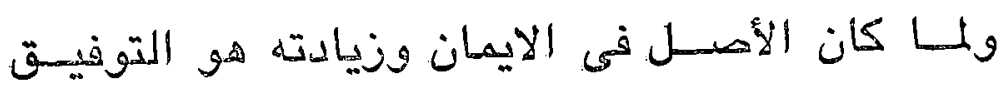

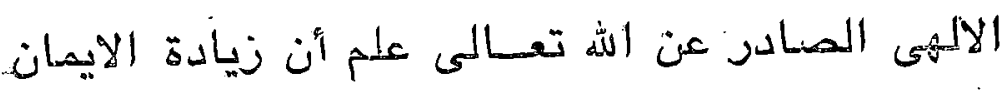

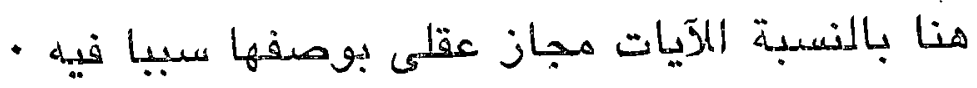

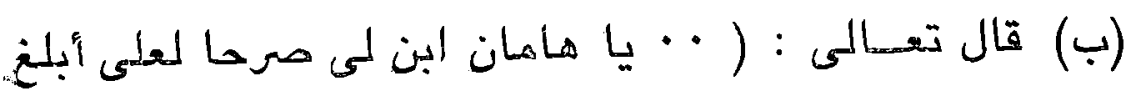

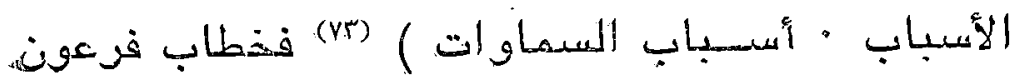

- r بورة الأنفـال الآية رقم

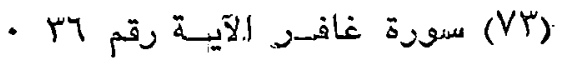


لـهاهان فيما اقتمدهـ القرآن الـكريم ، لا يـوحى بأنه

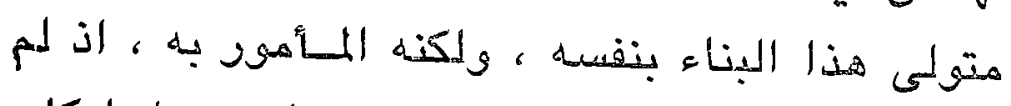

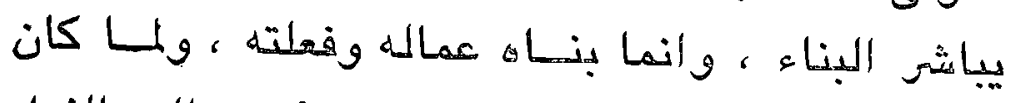

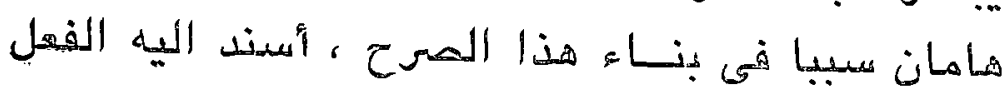

$$
\text { مجازا }
$$

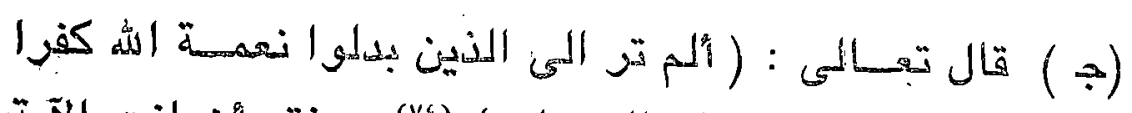

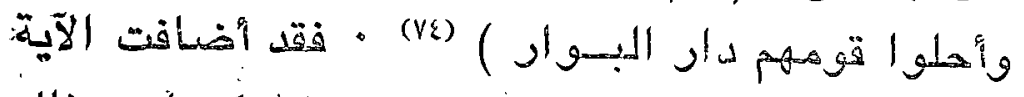

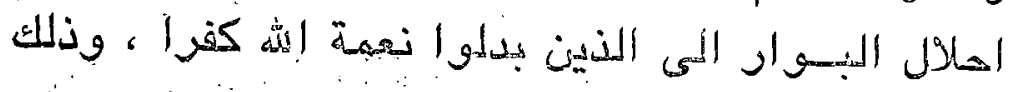

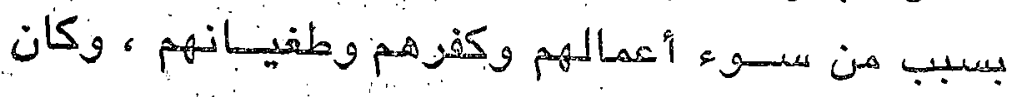

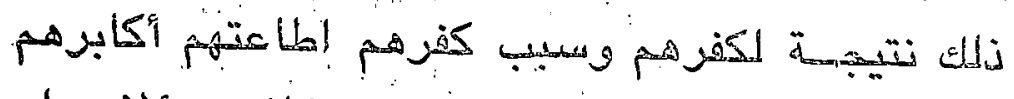

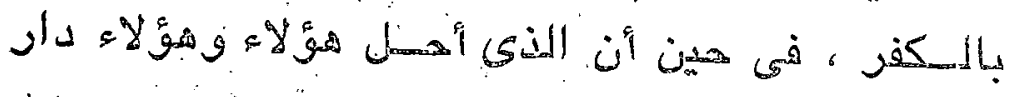

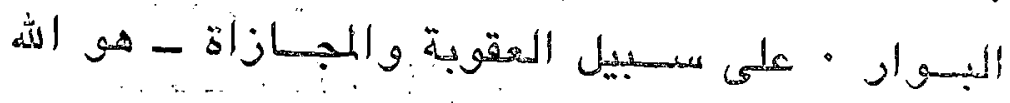

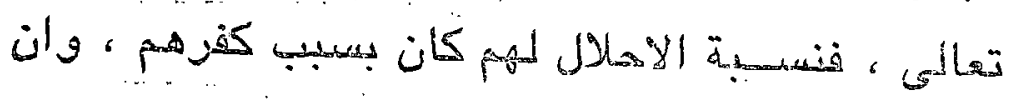
•

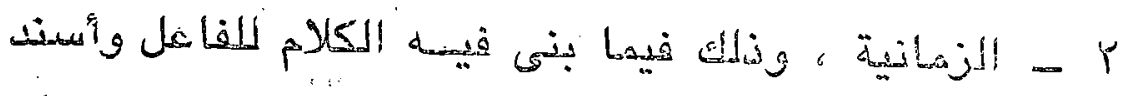

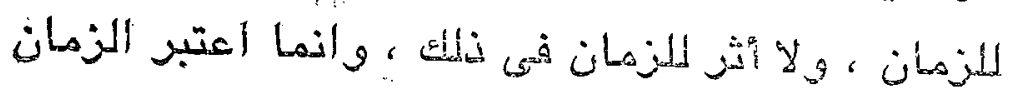

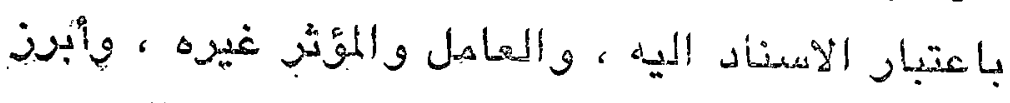

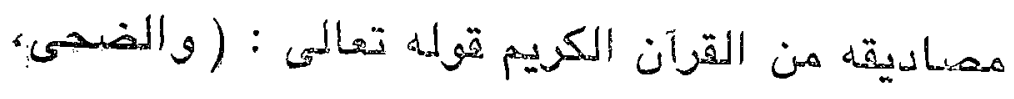

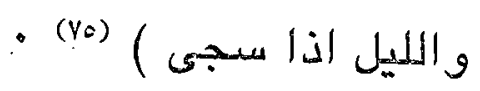

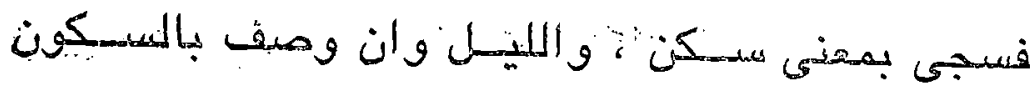

$$
\begin{aligned}
& \text { • برورة ابراهيم الآية رتم }
\end{aligned}
$$

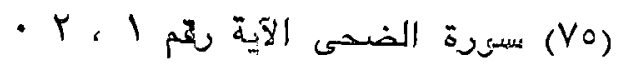




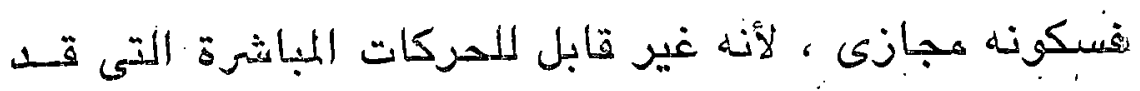

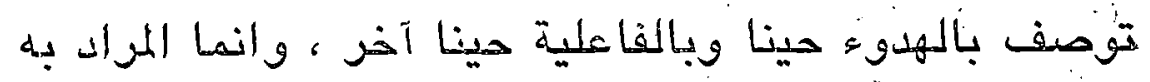

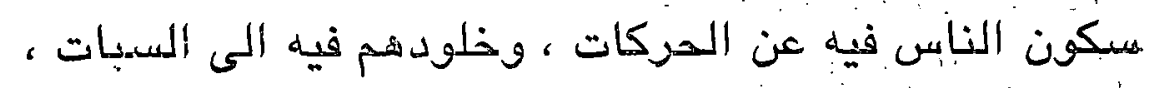

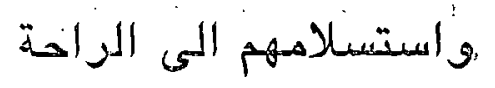

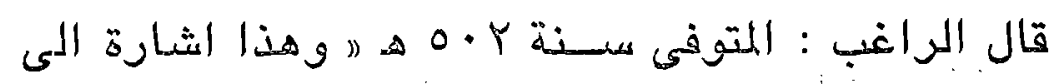

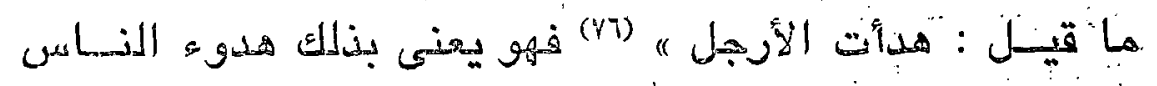

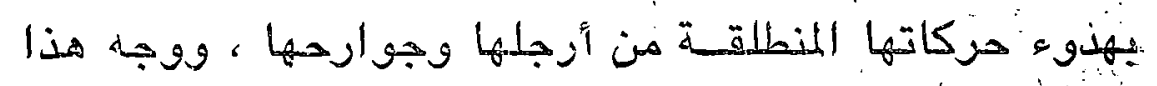

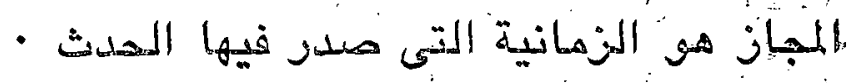

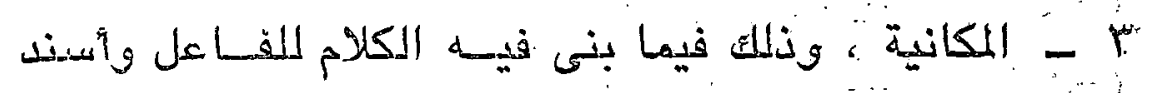

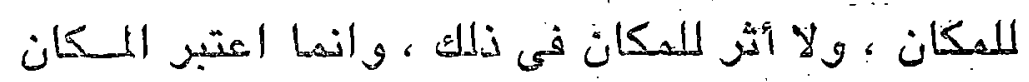

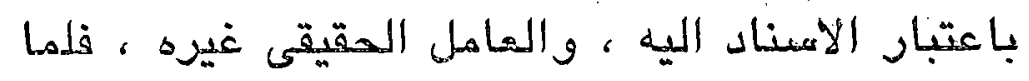

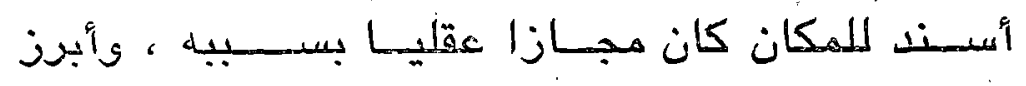

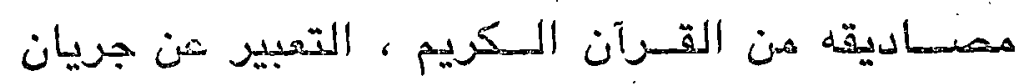

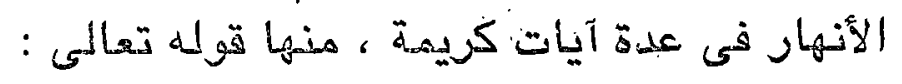

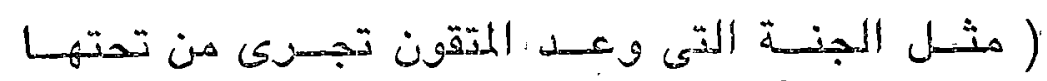

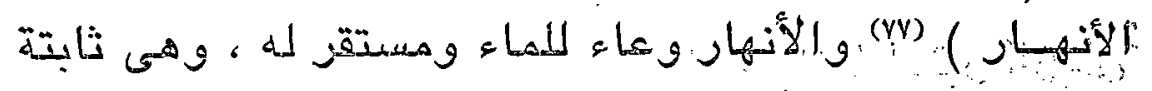

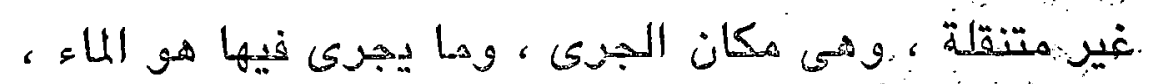

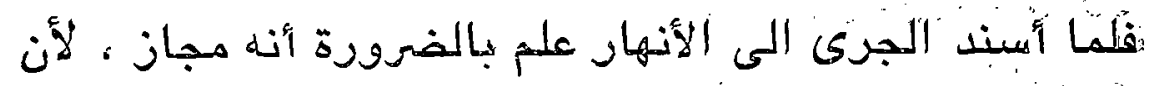

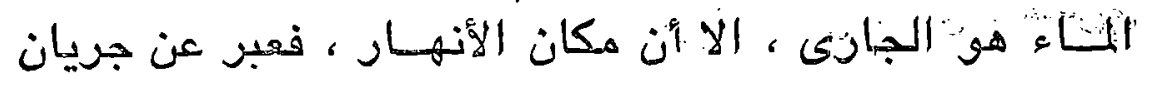

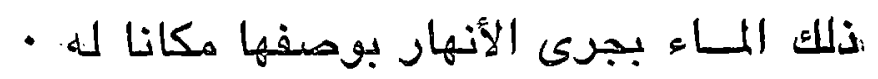

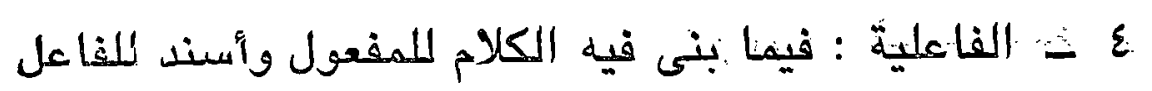
(V7)

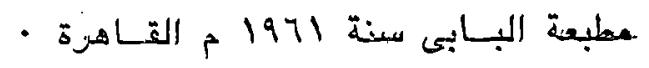

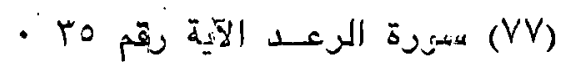


الهقيقى ، وقد ينظر لهذا بقىله تعالمى :

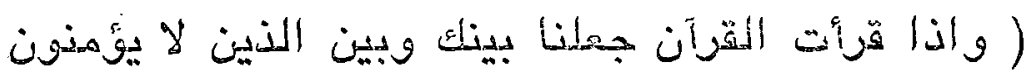

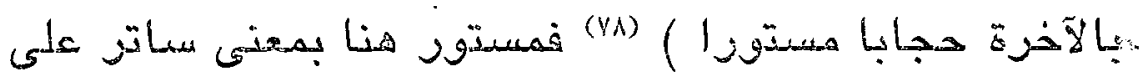

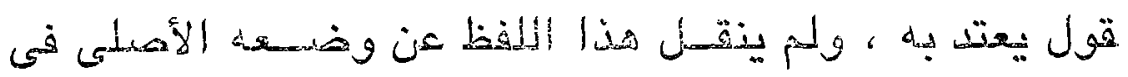

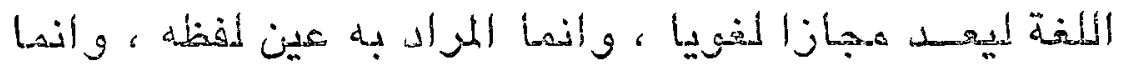

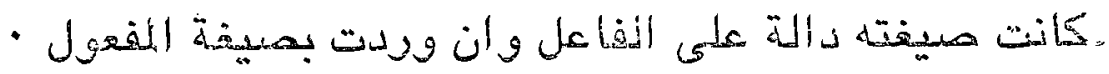

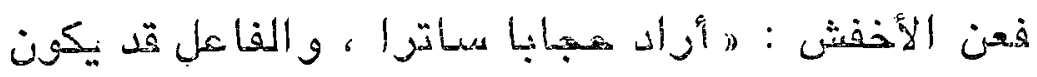

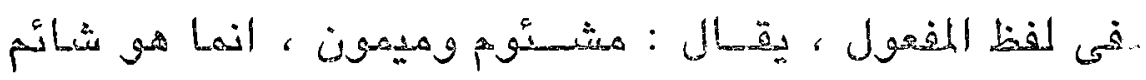

- (va) "وياهن

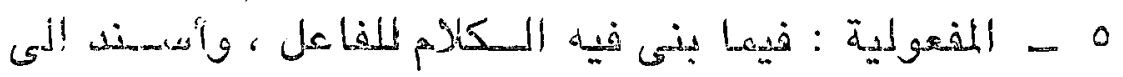

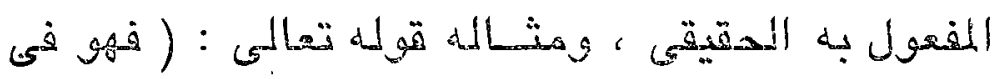

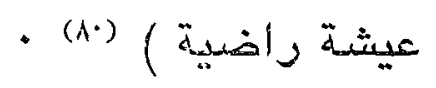

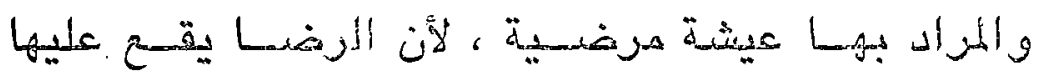

•

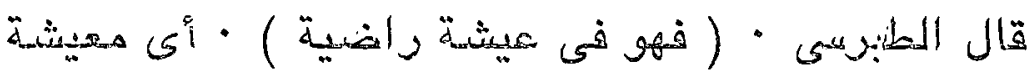

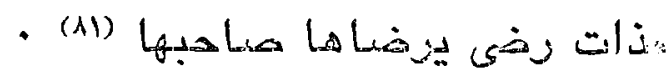

- T المصدرية ، وهو فيما بني فيه الكلام للفاعل ، وأسيند

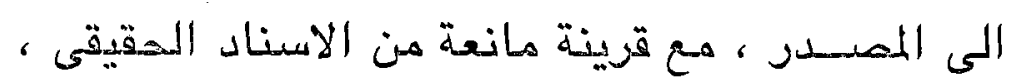

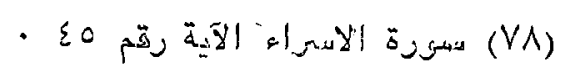

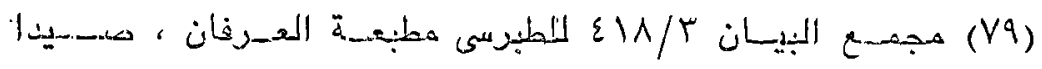

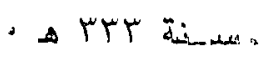

- V

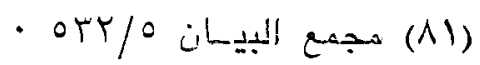


ومثثاله قوله تعـالمى : (فاذا نفخ في المسور نفخة:

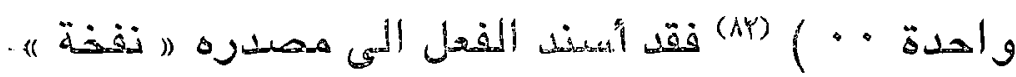

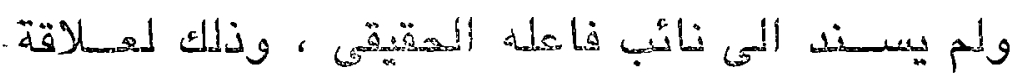

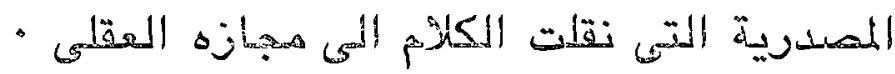

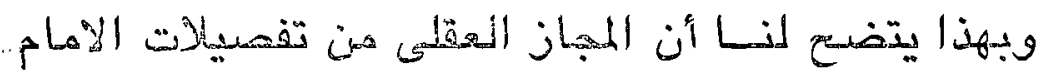

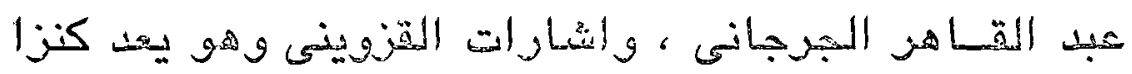

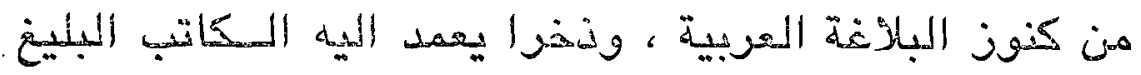

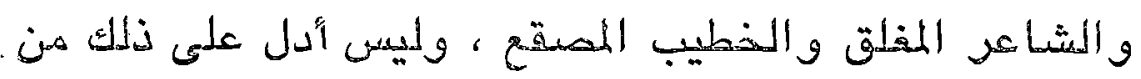

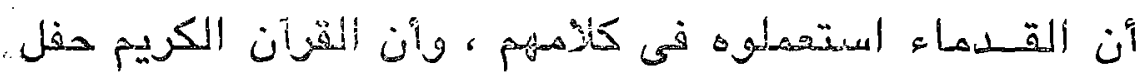

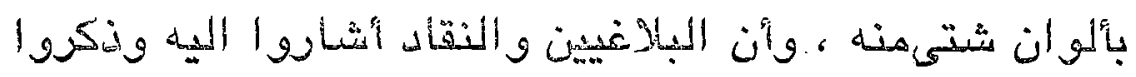

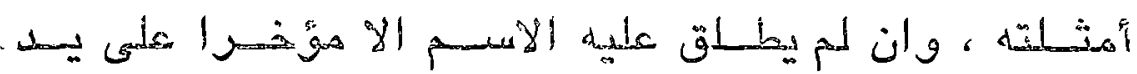

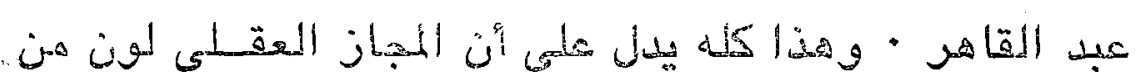

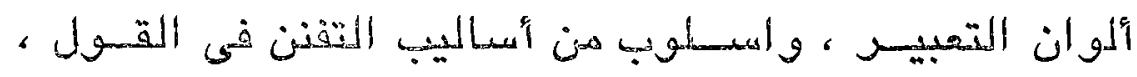

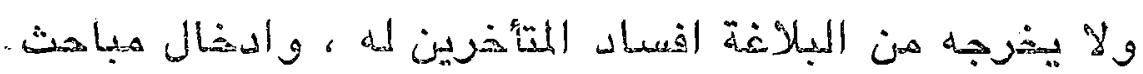

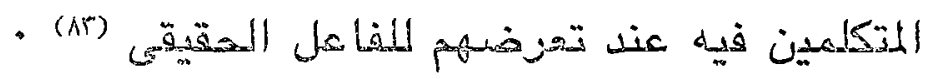

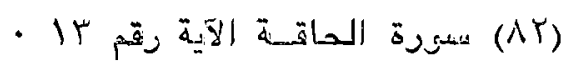

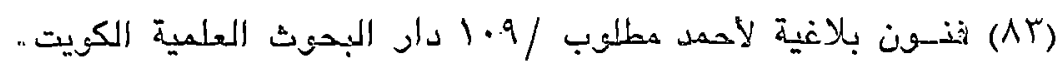

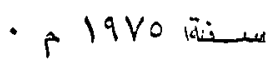




\section{المجيكاز المئسل}

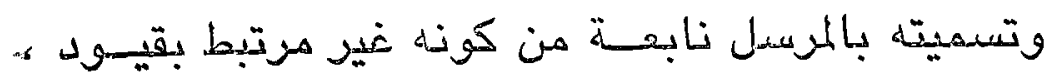

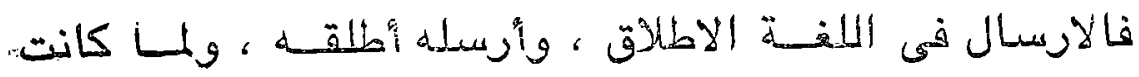

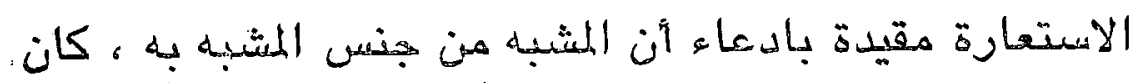

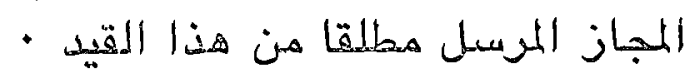

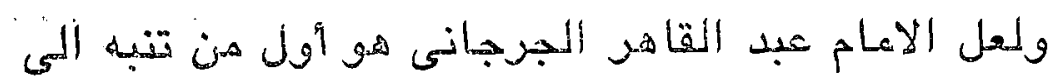

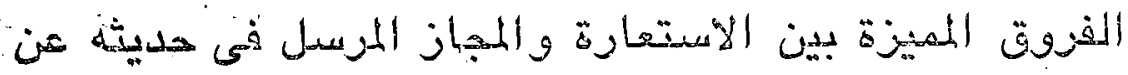

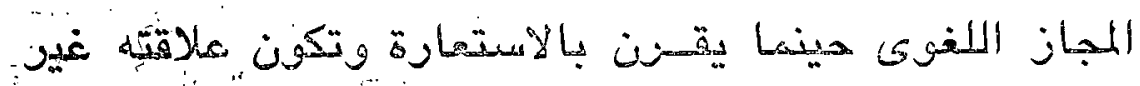

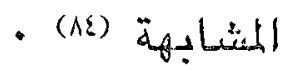

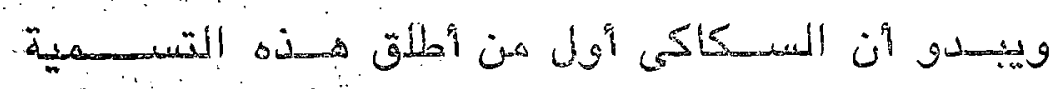

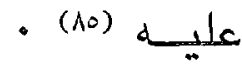

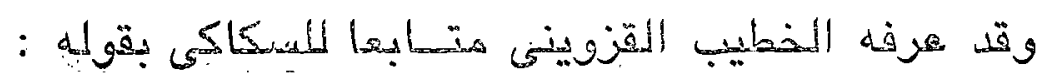

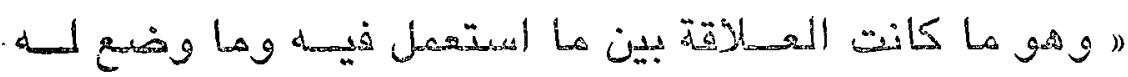

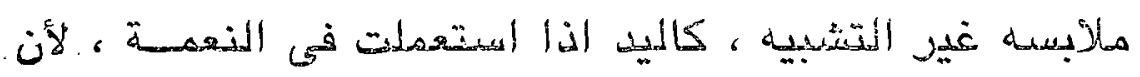

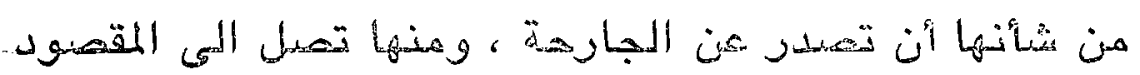

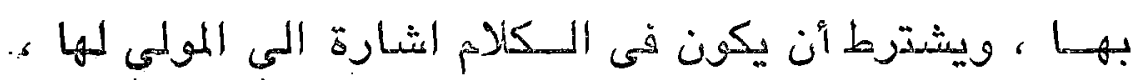

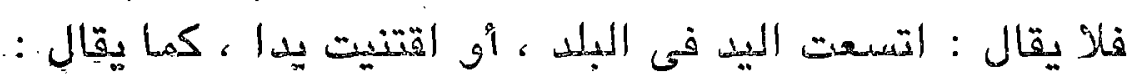

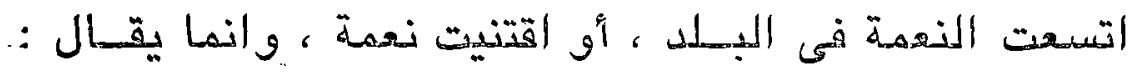

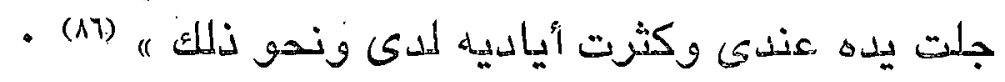

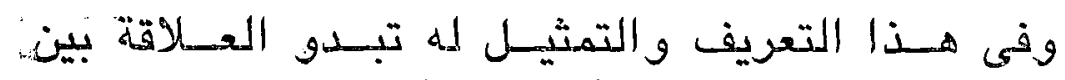

- YVY

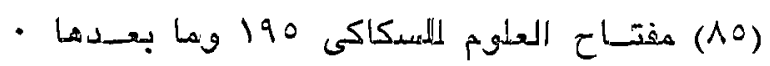

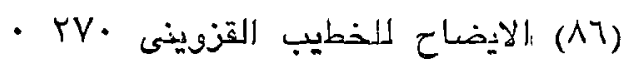




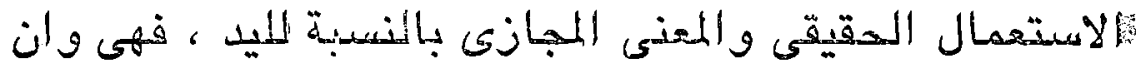

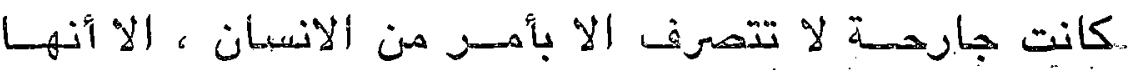

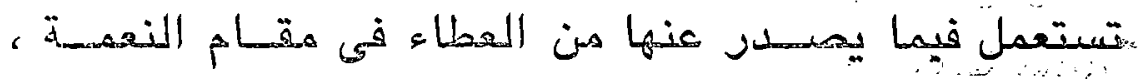

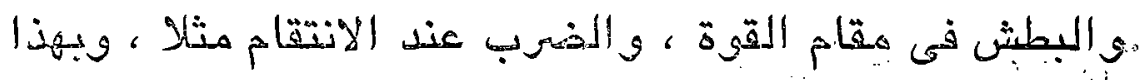

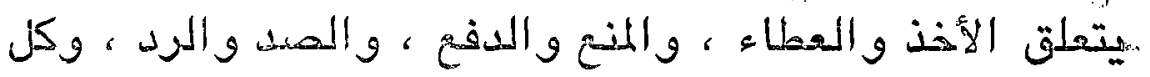

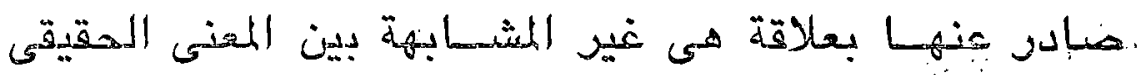

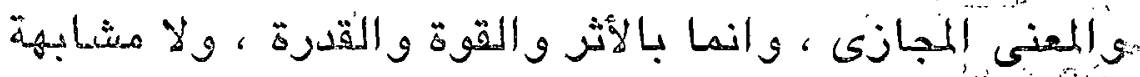

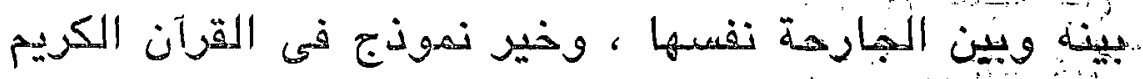

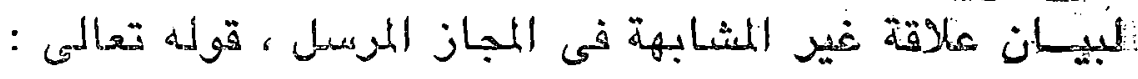

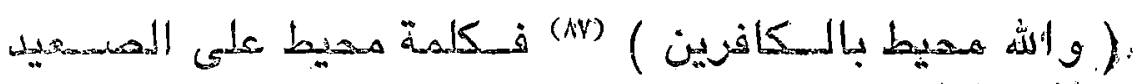

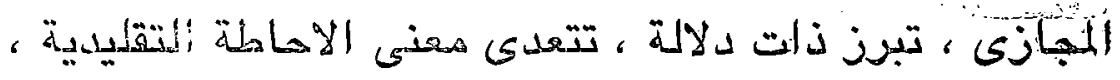

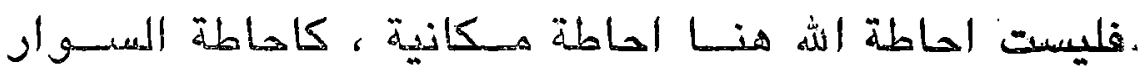

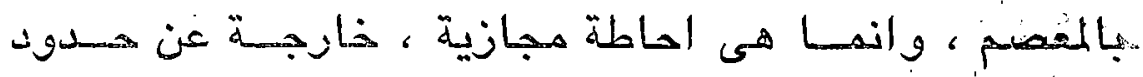

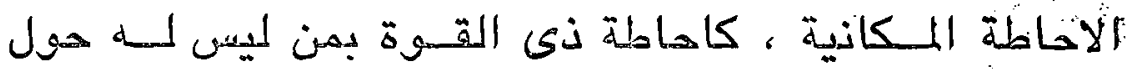

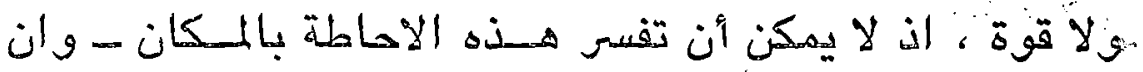

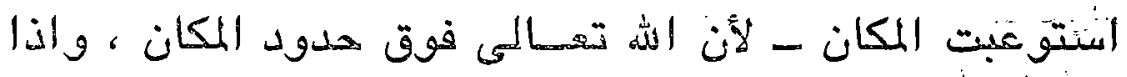

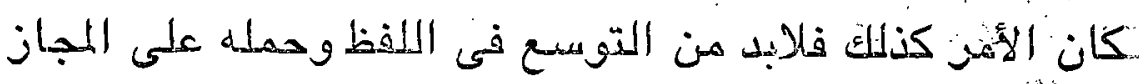

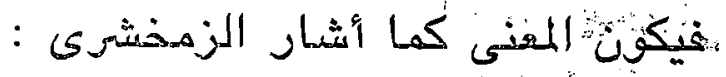

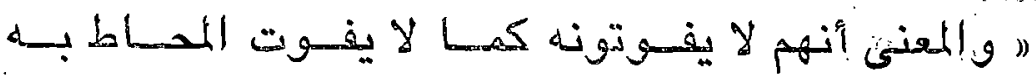

$$
\text { - (AN) حقيقة }
$$

واذا كان المحنى كذلك ، علمنا أن لا هثابهة بين المعنى.

$$
\begin{aligned}
& \text { - لمئورة البقــة الآية رقم } 19 \text { (AV) } \\
& \text { - 10/1 الكشاف للزمخشرى (11) }
\end{aligned}
$$


الحقيقى والمعنى المجبـازى ، فانصرف التهثيـل النى المجاز

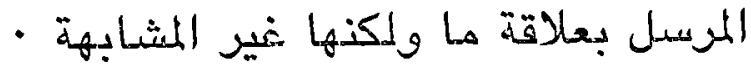

وجوه المجاز الئبسل :

توســح البلاغيون فى استذراج وجوه المجباز المرسبسله.

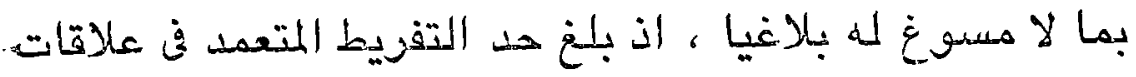

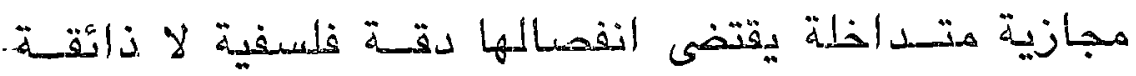

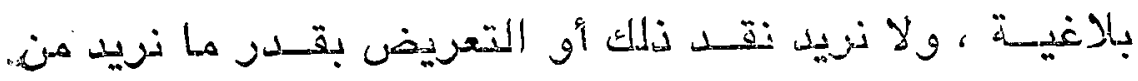

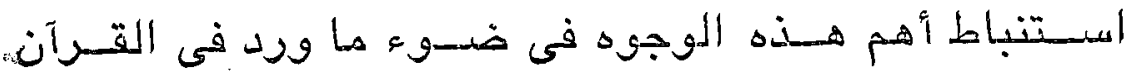
•الكريم

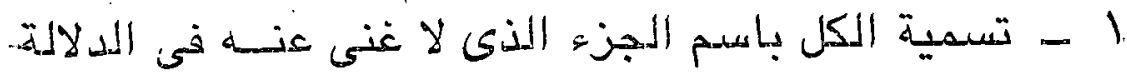

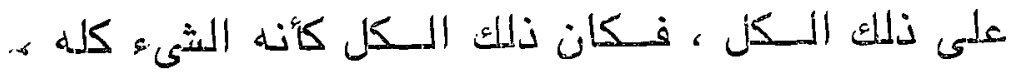

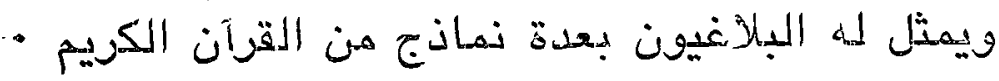

\section{: منهـL}

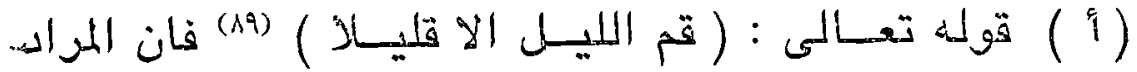

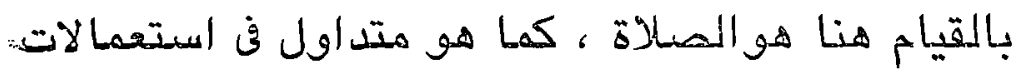

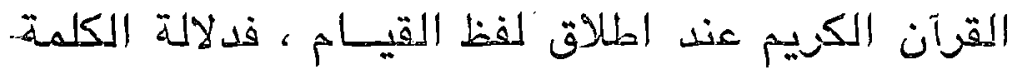

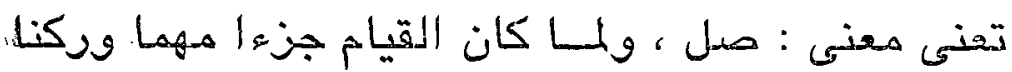

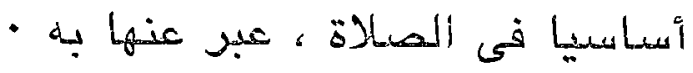
(ب) قوله تعالمىى : (ويبقى وجه ريك ) (•) فأن المراد بالوجيه.

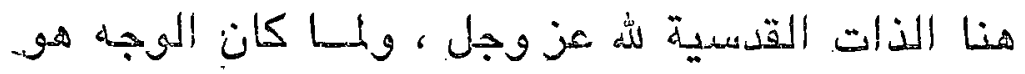




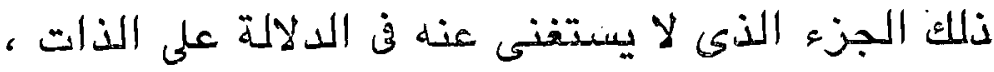

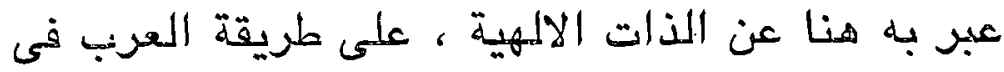

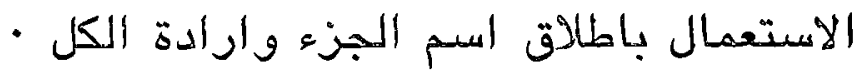

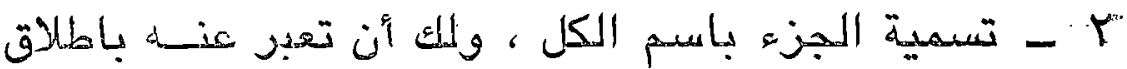

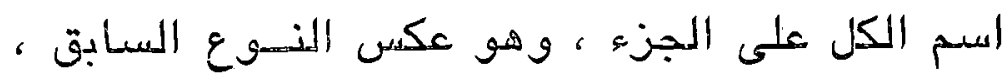

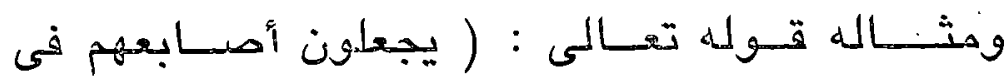

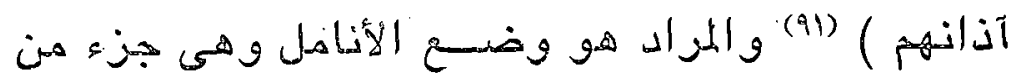

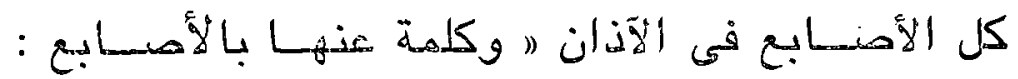

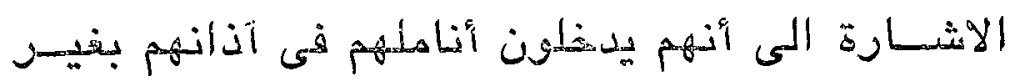

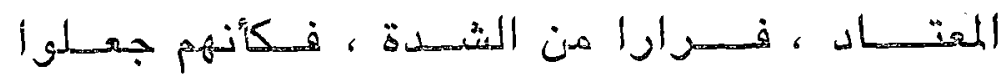

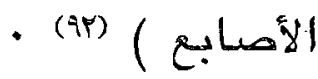

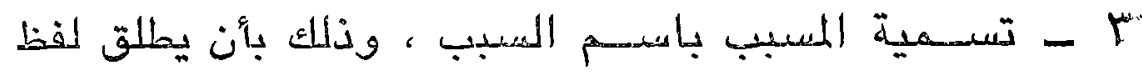

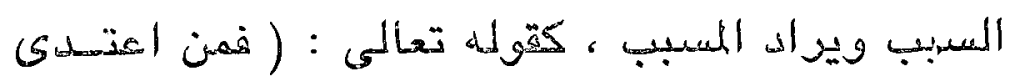

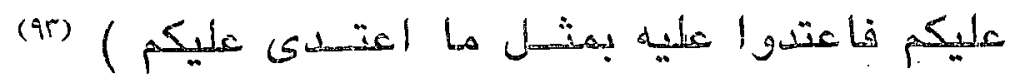

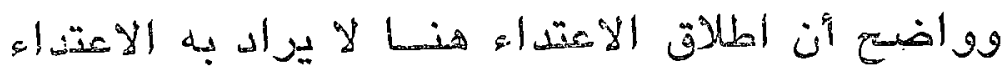

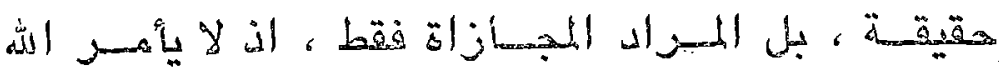

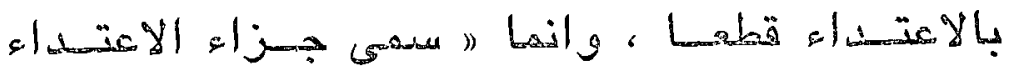

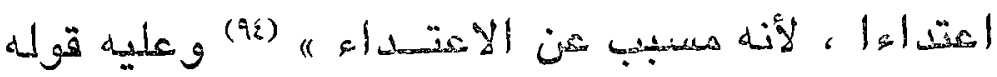

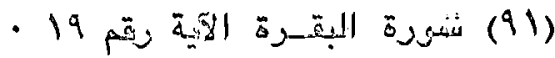

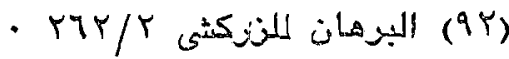

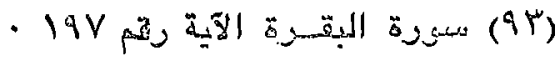

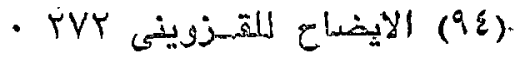


تعالى : ( وجزاء ســيئة سيئة مثلها ) (90) فقــــ عبر

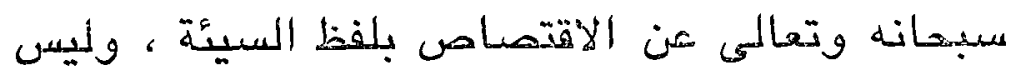

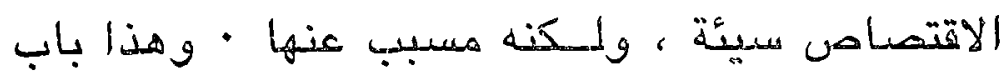

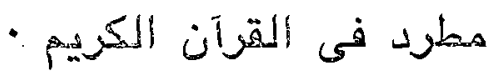

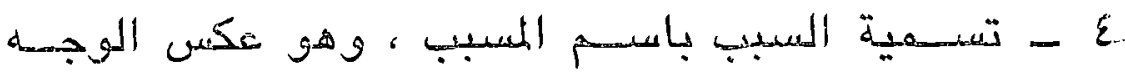

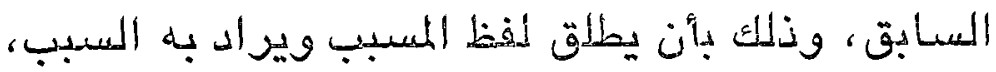

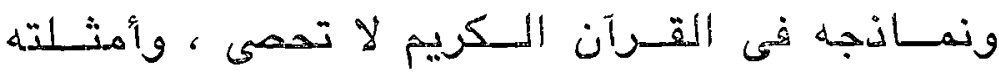

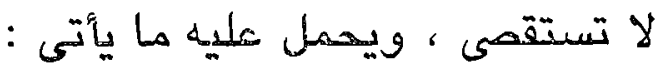

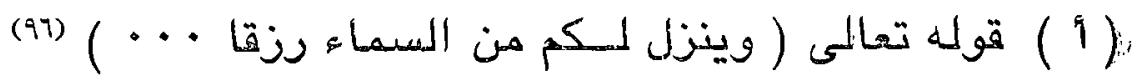
وواضح أن الرزق لا ينزل هـن السـهاء بهيتئه وكيفيته

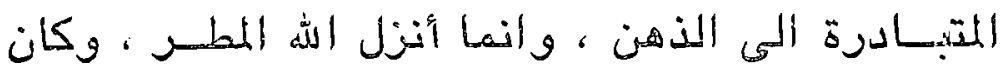

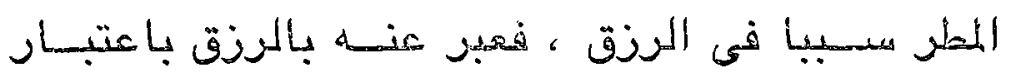
- السنبيبية

:(ب) قوله تعالمى : (ان الذين يأكلون أمو ال اليتـاهى ظلما

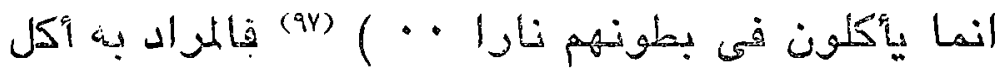

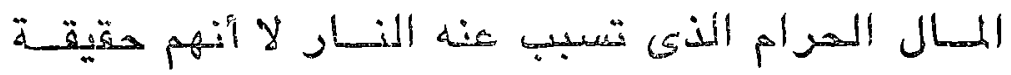

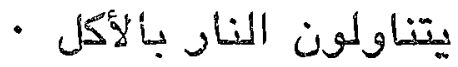

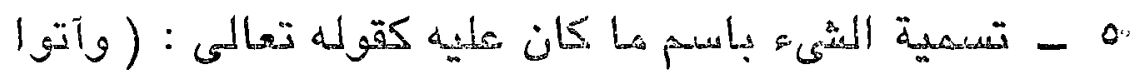

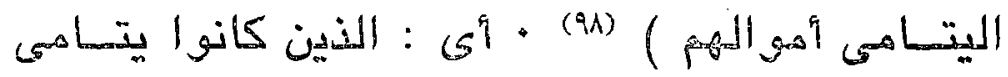

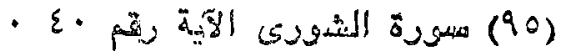

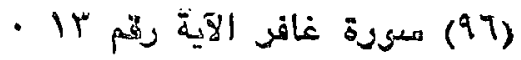

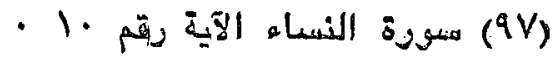

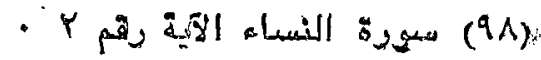


فيما مذى اذ لا يتم بعـد البلوغ · وكقوله تعسالمى :

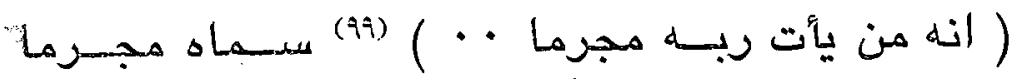

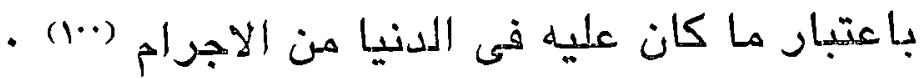
1 - 1

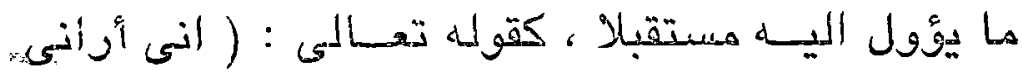

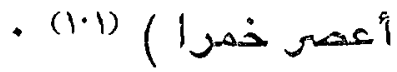

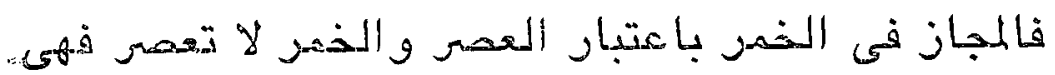

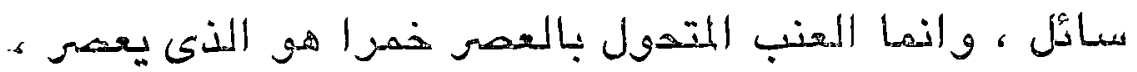

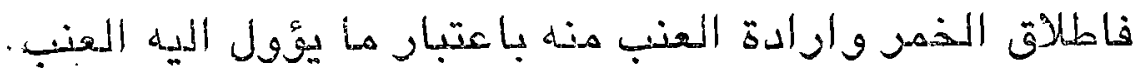
بعد العصى

والحق أن من وجوه المجاز المرسمل وعلالقاته هن ألكترة و الوفرة بهيث تستوعب أضعاف ما ذكرنا من نماذج ، وقيد.

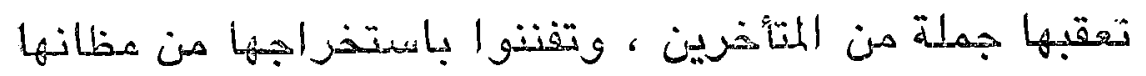

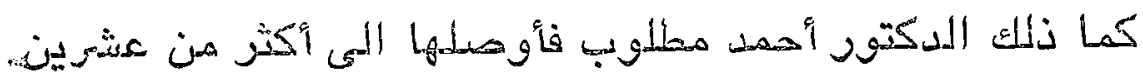

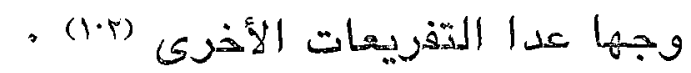

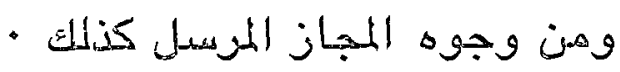

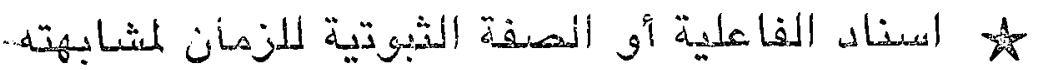

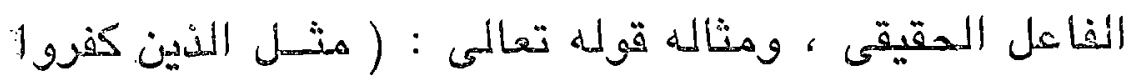

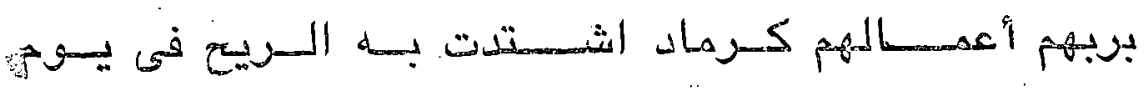

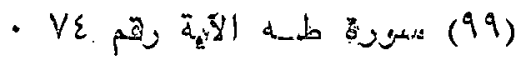

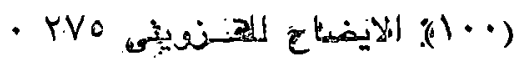

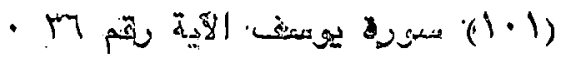

$\therefore 111$ - 111 (1-Y) 
- (1.r) (ماصف )

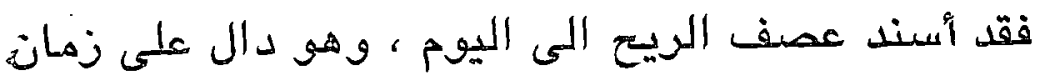

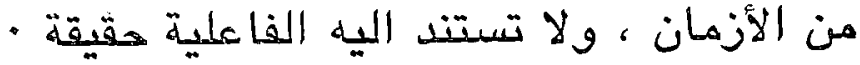

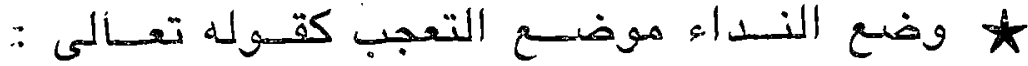

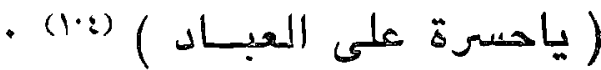

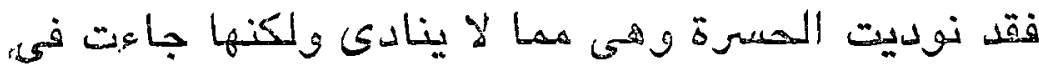

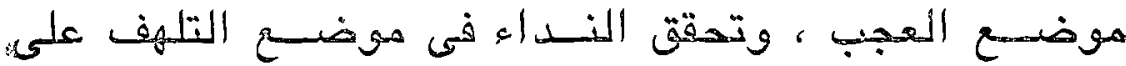
- المبـاد المثاد

丈 اطلاق الأمر وارادة الخبر ، ومثتساله قوله تعاليى :

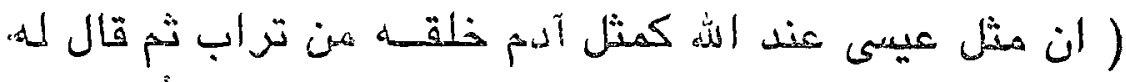
- كن فيكمن (1.0)

فان لفظلة كن تدل شيلي الأهسر ، ولكن الئزاد بها الخبر. والتقريز ، والتقرير فيها يكون : يكون فيكون ، أو على أنسيك.

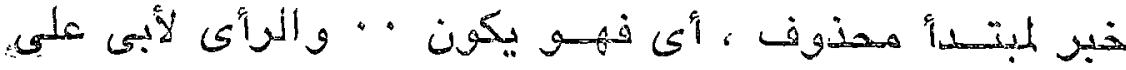

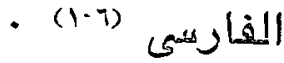

وفمي الختام لابل أن نشير المى دلالة ذاته أهمية بيـانية.

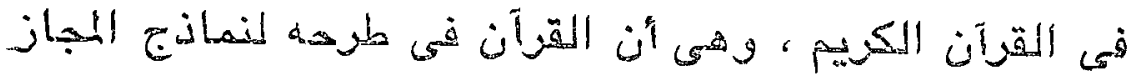

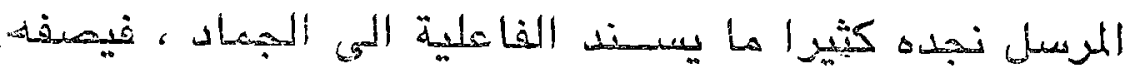

$$
\begin{aligned}
& \text { - IN } 11 \text { 吾 }
\end{aligned}
$$

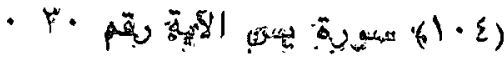

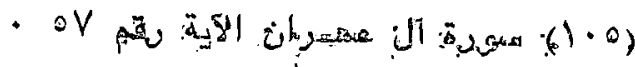

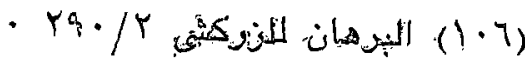

هات ( 
بالمركة ، ويشيع الحس بالكائنات الصامتة، ، فكأنها ناطقة

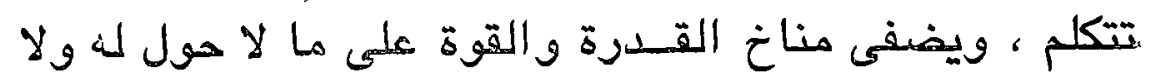

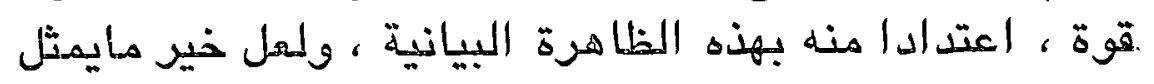
ذلك قوله تهالمى : ( وضرب الله مثلا قرية كانت أمنة هطمئنة

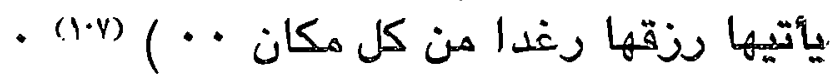

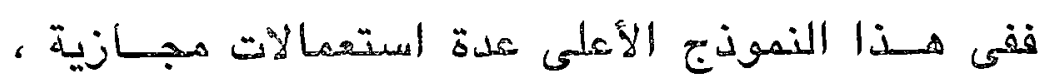

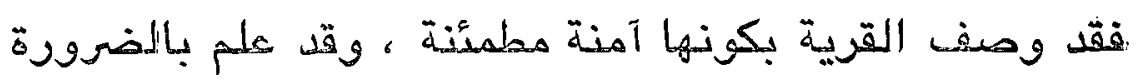

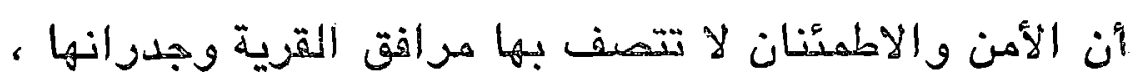

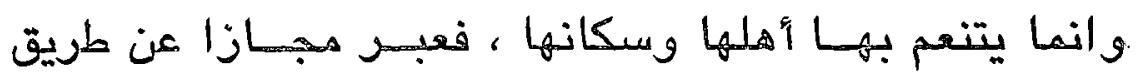

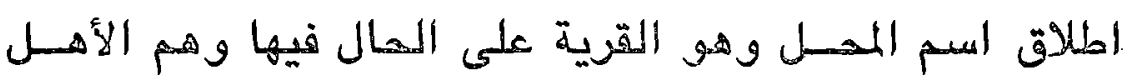

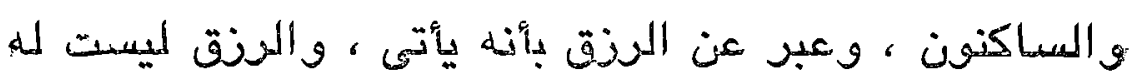

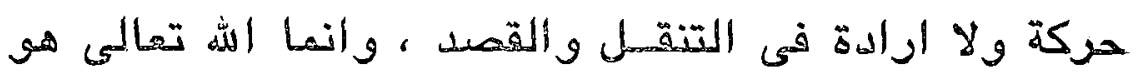

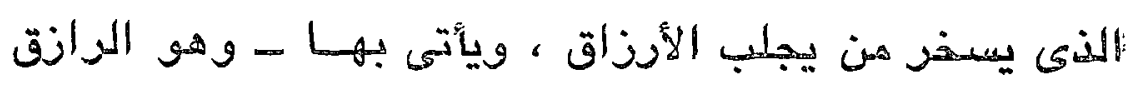

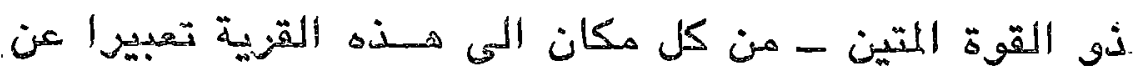

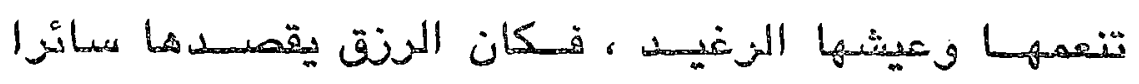

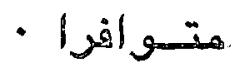

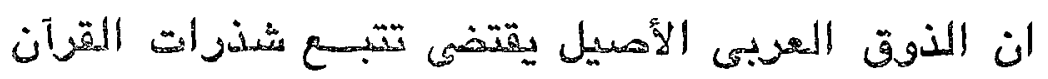

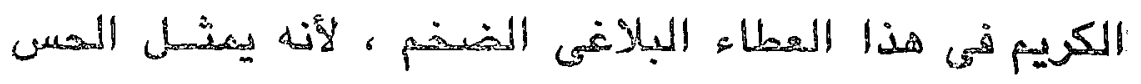

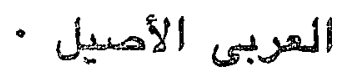

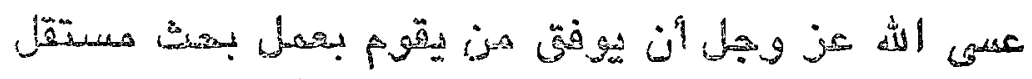
- pull H.

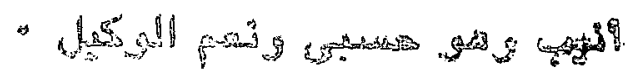




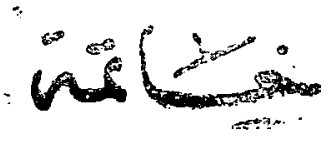

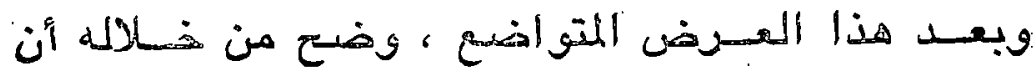

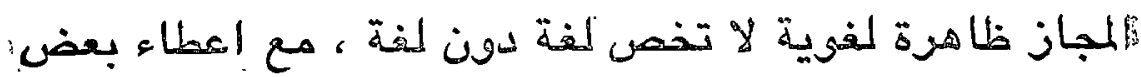

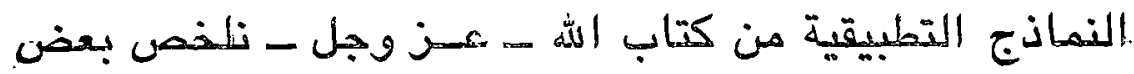

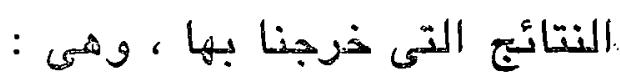

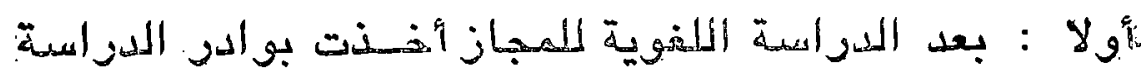

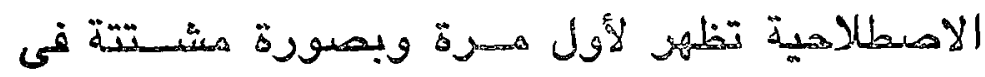

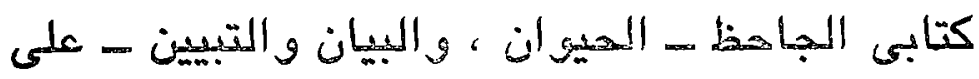

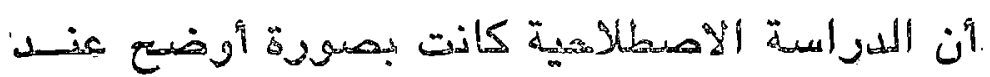

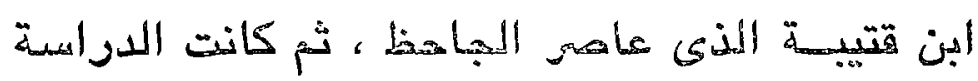

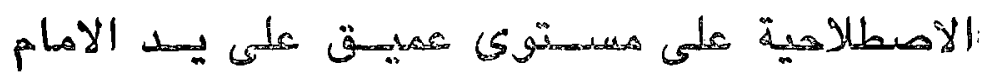

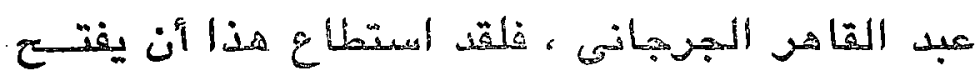

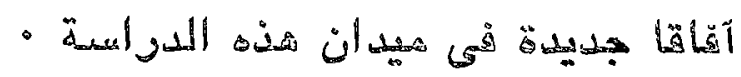

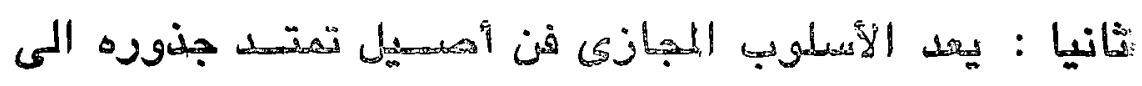

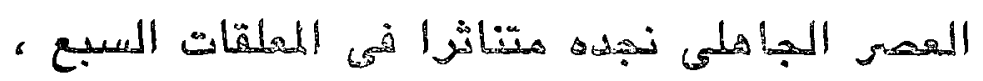

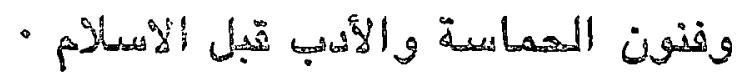

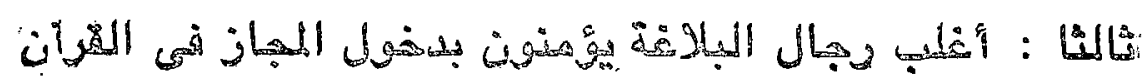

$$
\text { الكرئم } 2
$$

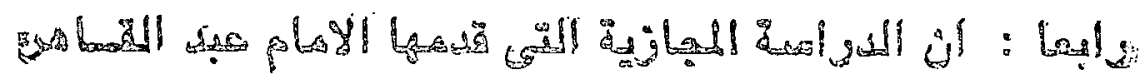

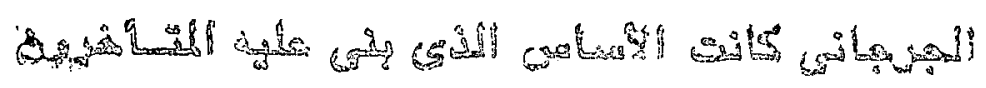




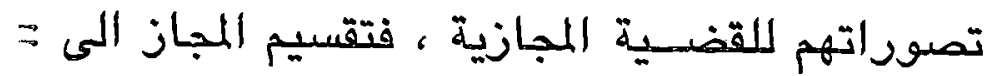

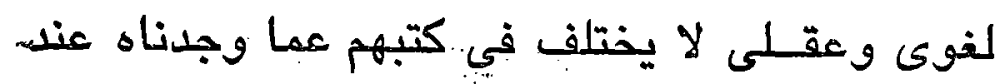

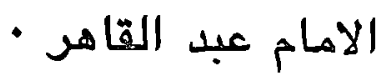

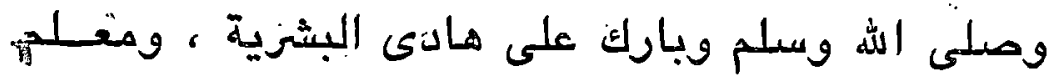

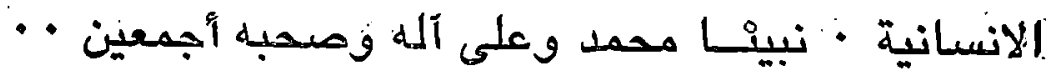




\section{- rVY - \\ المصـادر والئراجـح}

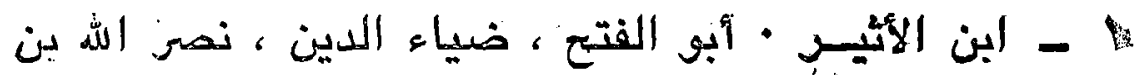

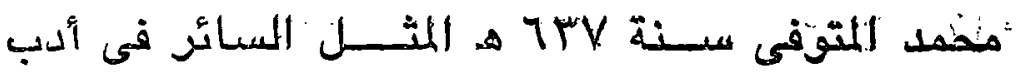

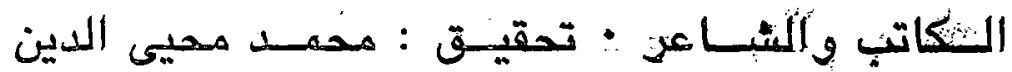

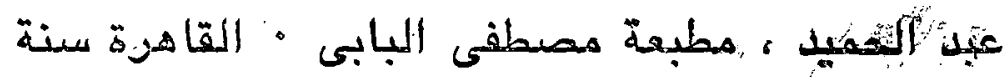

$$
\therefore \text { सा } 199
$$

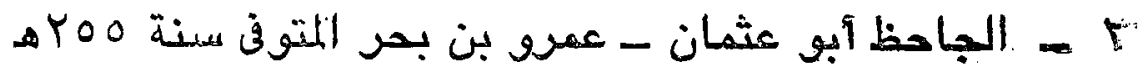

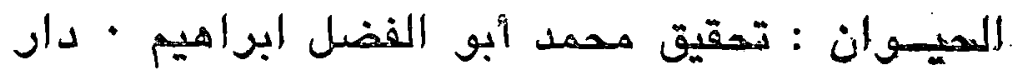

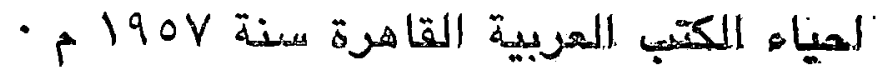

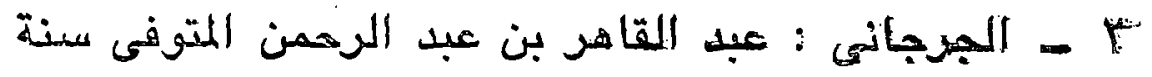
كا

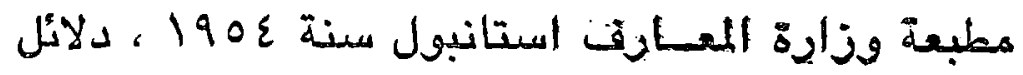
الاعجاز : تصحيع محمد عبله مطبعة المنسار القاهرة سنة

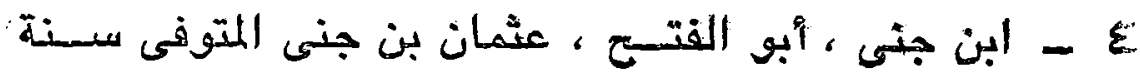

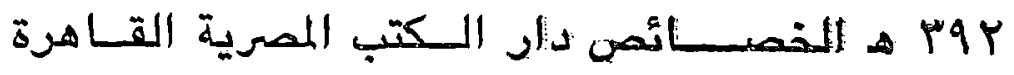
مينة ror

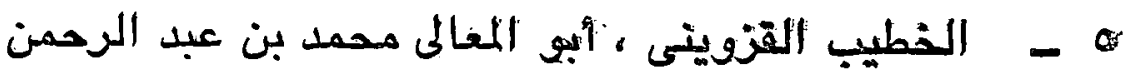

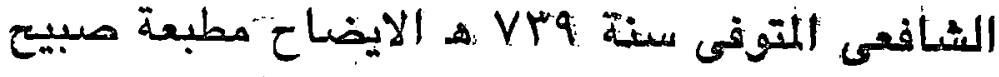
سنة |

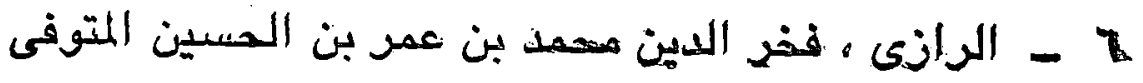

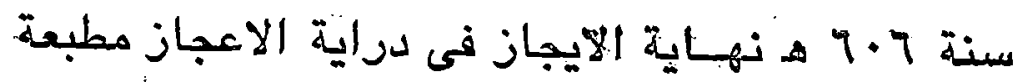

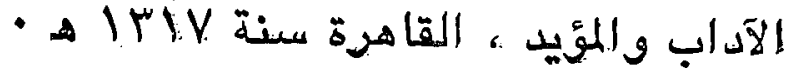


- V الزركثى ، بدر المدين ، مهمل بن مبد الله المتوفى سنة

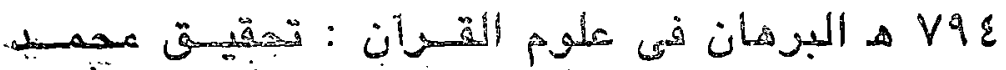

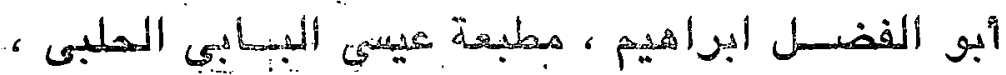

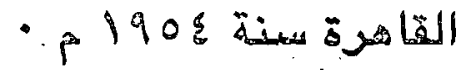

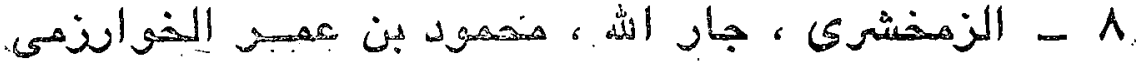

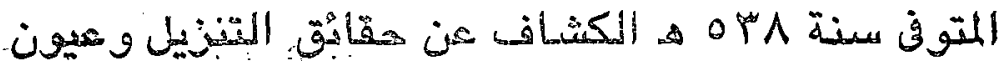

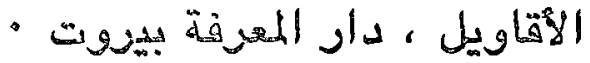

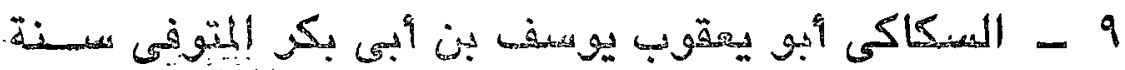

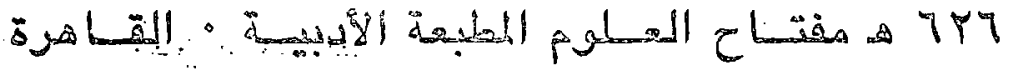
- ITIV Lives

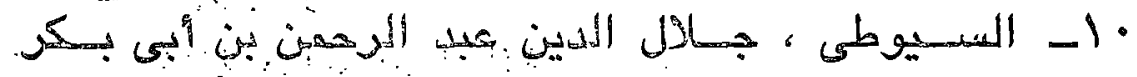

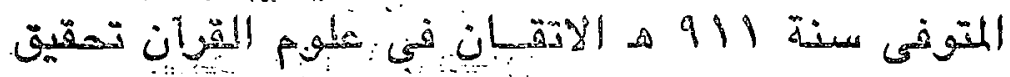

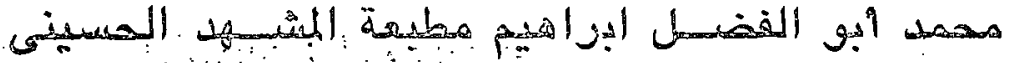

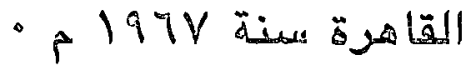

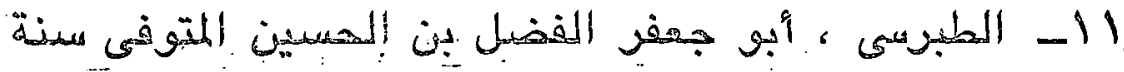

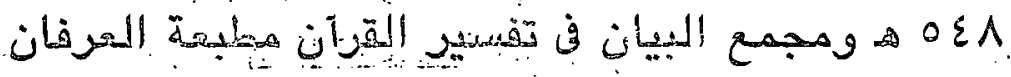

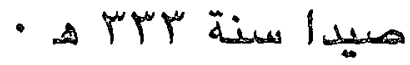

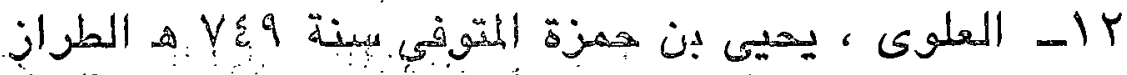

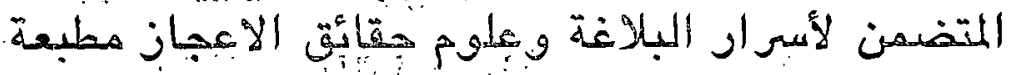

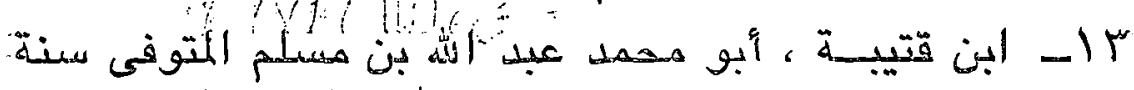

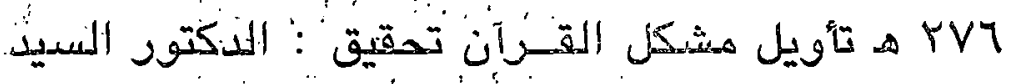

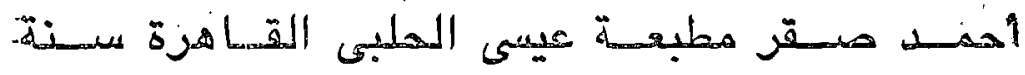


- rvo -

عا- ابن قيسم الجيوزية ، أبو عبذ الأه معمسد بن أبى أيوب

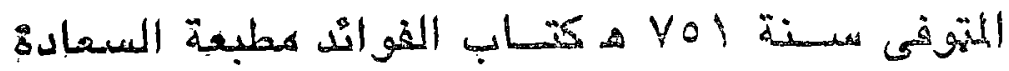

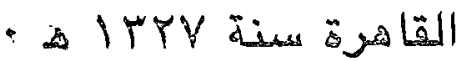

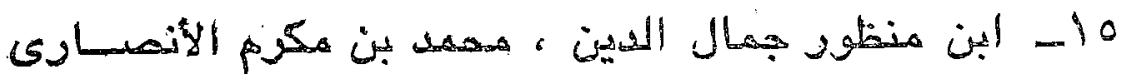

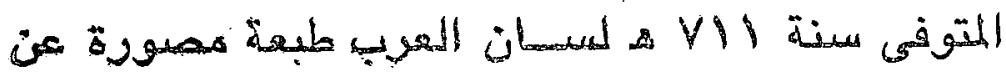

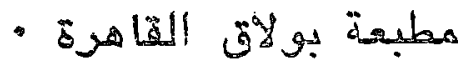

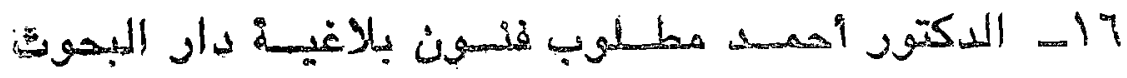

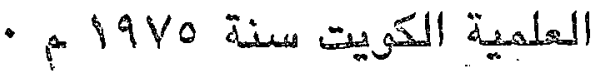




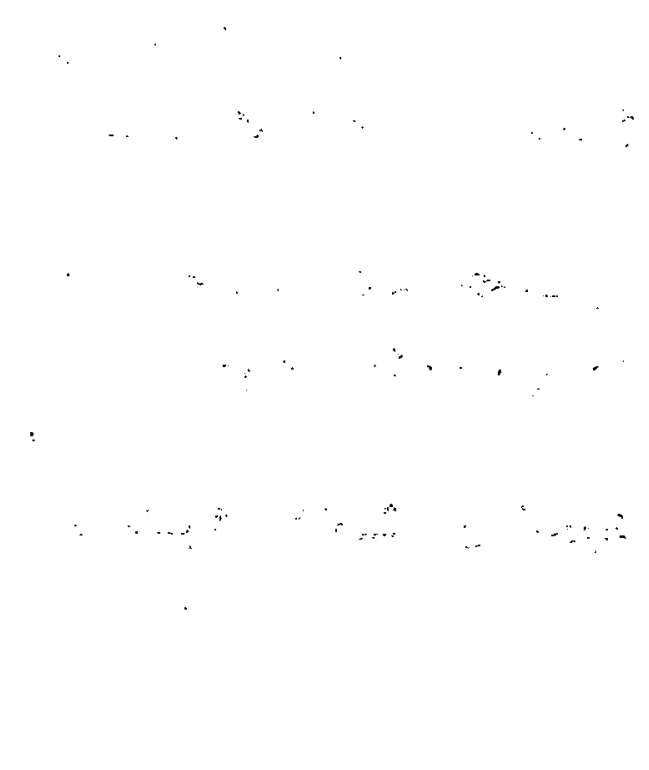

